В книге опубликованы результаты многолетних исследований микобактерий, в частности лепры и туберкулеза с помощыю микобактерий. Материалы, представленные в книге, могут быть использованы для совершенст вования диагностики микобакт ериозов. Кроме познавательного значения, материальь по электроннои микроскопии микобактерий имеют и большое

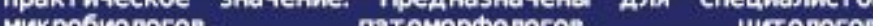
микроомологов, читологов. дермиинских и биологических учебинх заведений.

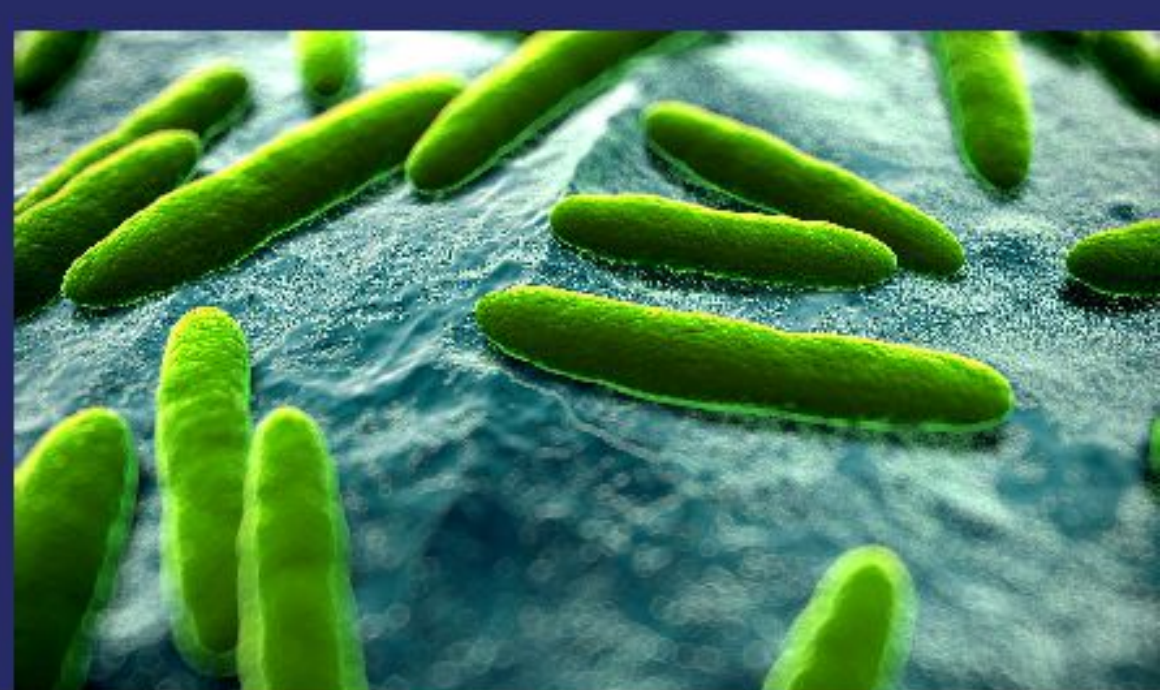

Гузель Генатуллина Александр Маслов

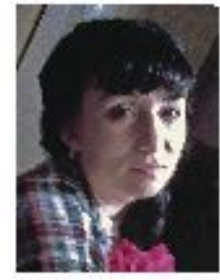

Гузель Генатуллина

Кандидат биологических наук, 1979 г.р. Работает в нии по изучению лепры, владеет методами элект ронной микроскопии. Изучает микобактерий во взаимоот ношении с клетками организма-хозяина. Участ вует в разработках растительных препаратов обладающих прот ивот уберкулезной

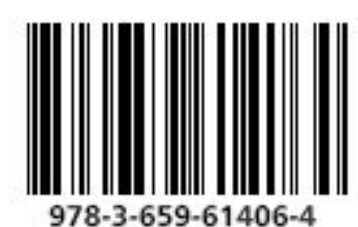

\section{Ультрацитохимические характеристики некоторых микобактерий}

\section{AM $\overline{\text { IAMEERT }}$}


УДК 579.61+616-094

ББК 28.4+52.5

M31

\section{УЛЬТРАЦИТОХИМИЧЕСКИЕ ХАРАКТЕРИСТИКИ НЕКОТОРЫХ МИКОБАКТЕРИЙ}

А.К. МАСЛОВ, Г.Н. ГЕНАТУЛЛИНА 


\section{СОАЕРЖАНИЕ}

Предисловие 3

Специальная терминология, размеры и условные обозначения, использованные в тексте и на рисунках Введение

A. Mycobacterium leprae

1. Морфология и культуральные свойства

2. УАьтраструктура Mусоbacterium leprae

3. Э^ектронно-цитохимическое изучение Mycobacterium leprae

3.1. Аокализация антигенов Mусоbacterium leprae в гранулемах больных

3.2. Ферментный состав Мусоbacterium leprae 4 5

3.3. Аизосомальные ферменты макрофрагов при мепре 6

(
7

3.4. Значение миелопероксидазы фагоцитов 21

3.5. Совершенствование модели Шепарда 28

4. Оценка функционального состояния мепрозных макрофагов 31

5. Покоящиеся формы Mycobacterium leprae 33

6. Поражения сосудов при мепре 45

Б. Mycobacterium tuberculosis

1. Морфология, ферментные и культуральные свойства Mycobacterium tuberculosis 49

2. УАьтраструктура Mycobacterium tuberculosis 51

3. Э^ектронно-цитохимическое изучение Mycobacterium tuberculosis 57

B.Mycobacterium kansasii, Mycobacterium marinum, Mycobacterium skrofulaseum, Mycobacterium avium, Mycobacterium intracellulare, Mycobacterium smegmatis

1. Морфология, ферментные и культуральные свойства представителей нетуберкулезных микобактерий 61

2. УАьтраструктура преАставителей нетуберкулезных микобактерий 64

3. Э^ектронно-цитохимическое изучение преАставителей нетуберкулезных микобактерий

Заключение

Аитература 79 


\section{ПРЕАИСАОВИЕ}

В книге опублиикованы результаты многолетних исследований микобактерий, в частности мепры и туберкулеза с помощью электронной микроскопии, на основе полученных данных предлагаются новые подходы к изучению структуры микобактерий. А^я сравнения приводятся Аанные исследований преАставителей разных групп микобактерий (Mycobacterium kansasii, Mycobacterium marinum, Mycobacterium skrofulaseum, Mycobacterium avium, Mycobacterium intracellulare и Mycobacterium smegmatis).

Биологическую роль органоидов и компонентов кАеток нельзя выяснить только посреАством электронно-микроскопического изучения ультраструктур. Эту задачу можно решить путем комплексного исследования, поэтому авторами представлены данные и об иммуноцитохимическом строении микобактерий. Проанализированы собственные материалы и митературные Аанные по морфологии и электронной цитохимии микобактерий.

Материалы, преАставленные в книге, могут быть использованы Аля совершенствования диагностики микобактериозов. Кроме познавательного значения, материалы по электронной микроскопии микобактерий имеют и большое практическое значение. Предназначены Аля специалистов микробиологов, патоморфологов, цитологов, Аерматовенерологов, а также студентов и слушателей, медицинских и биологических учебных заведений. 


\section{СПЕЦИААЬНАЯ ТЕРМИНОАОГИЯ, РАЗМЕРЫ И УС ОВНЫЕ ОБОЗНАЧЕНИЯ, ИСПОАЬЗОВАННЫЕ В ТЕКСТЕ И НА РИСУНКАХ}

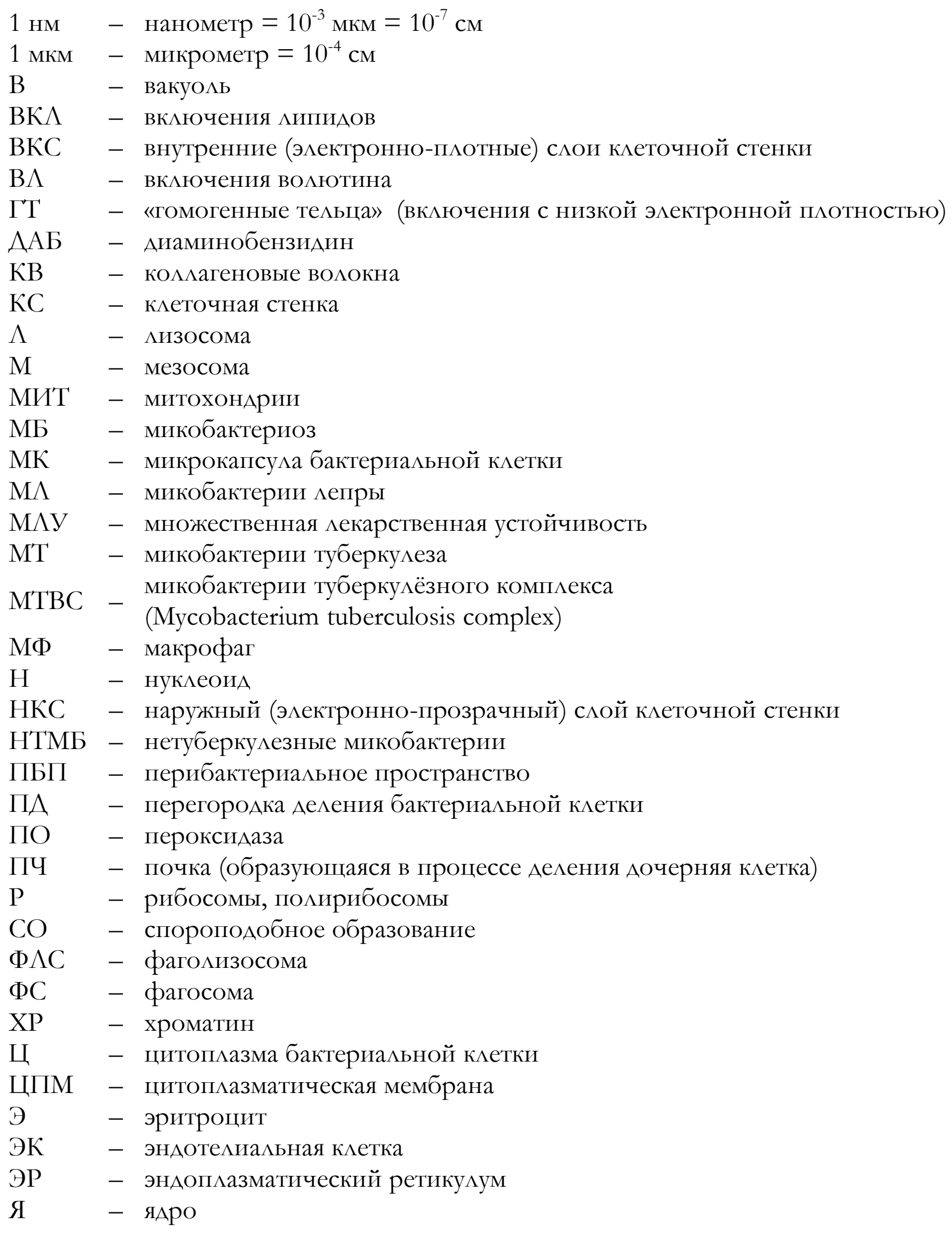




\section{ВВЕАЕНИЕ}

Микобактерии явцяются группой микроорганизмов, важной как с биологической, так и с меАицинской точки зрения. Их особая кислотоустойчивость, факт принаАлежности к ним патогенных виАов, среАи которых находятся и возбудители мепры и туберкулеза, всё еще поражающих мицАионы АюАей, подчеркивает значение этих микроорганизмов.

В этой книге представлен совокупный материал многолетних экспериментальных исследований по изучению ультраструктуры микобактерий мепры (МА), микобактерий туберкулеза (MT) и некоторых нетуберкулезных микобактерий (НТМБ).

Э^ектронная микроскопия Аала ценную информацию Аля изучения бактериальных клеток как самостоятельных структур, так и во взаимосвязи с организмом-хозяином. Микобактерии мепры и микобактерии туберкулеза изучались в материале от больных. Патогенные и условно-патогенные штаммы микобактерий изучались в культурах.

Согласно последнему изданию «Определителя бактерий Берджи» (IX изА.) род Mycobacterium вкАючает почти 50 вилов. В публикациях послеАних мет встречаются сведения о наличии 100 видов микобактерий [28]. Род Mycobacterium вкАючает виды бактерий, сходные по морфологическим и тинкториальным свойствам, но имеющие Аостаточно значимые разАичия межАу собой по биологическим свойствам.

По единодушному утверждению исследователей, по электронномикроскопической картине отличить МТ от MА невозможно. Поэтому морфологические структуры нельзя трактовать функционально, рассматривая только микрофотографии без применения Аругих методов. Электронная микроскопия нашла тесные контакты с биохимией, биофизикой, иммунологией и генетикой. Такие методы исследования, как электронная гистохимия, электронная авторадиография, электронная иммунохимия, стали основой Аля создания функциональной ультраструктурной морфологии. Электронно-цитохимические и электронно-иммунохимические методы [17] использовали Аля выявления ферментов и антигенов. Метод негативного контрастирования использовали с целью изучения поверхности культивируемых бактерий.

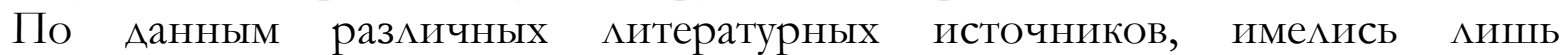
разрозненные сведения об ультратонком строении МА [43, 94, 114,144, 163], но наиболее полного описания биологических свойств микобактерий мепры в них нет.

Мы понимает всю трудность и сложность толкования найденных образований и хотим, чтобы наша работа не только внесла новое в познание морфологии этих возбудителей, показала их сложное строение, но и побудила к Аальнейшим электронно-микроскопическим исслеАованиям, поискам разными методами объяснения функционального назначения найденных образований, а кАиницистам помогла найти новые пути толкования некоторых явлений при заболеваниях. 


\section{A. Mycobacterium leprae}

Несмотря на то, что на сегодняшний день глобальная ситуация по мепре значительно улучшилась [19], число новых случаев заболевания, выявленных в течение 2011 года, составило 219075 человек [1]. К большому сожалению, статистика заболеваемости остаётся неутешительной, так как до сих пор нет единого мнения по многим важным вопросам эпидемиологии мепры. Актуальной остается проблема совершенствования методов терапии больных, потому что даже современные методы предполагают большую Алительность мечения и не гарантируют от развития мекарственной устойчивости и рециАивов [21].

$\Lambda$ епра - это одно из Аревнейших заболеваний, о котором упоминается ещё в Ветхом завете. В толковом словаре Владимира Ивановича Ааля этой болезни Ааётся следующее описание: наследственная $u$, может бъгть, заразительная накожная (худосочная) болезнь lерга, о которой много говорится в Священном Писании. В то время она походила на злокачественный мишай, переходящий в гнойные язвв, отчасти и понвгне известныцй на востоке; вот описание его: И узрит жрец язву на кожи плоти его и влас в язве изменится в бело, и взор язвы умален от кожи плоти его (т. е. впадиной), язва проказвг есть, Аевит, XIII, 3. Ныне проказой зовут довольно редкуго болезнь утолщения и обезображения кожи, с гнойныгми язвами и конечныгм истощением, изнурением [79].

В современной формулировке описание мепры звучит следующим образом: $\Lambda$ епра (Lepra), синоним: Болезнь Хансена, хансеноз, хансениаз, устаревшие названия: проказа, elephantiasis graecorum, lepra arabum, lepra orientalis, финикийская болезнь, satyriasis, скорбная болезнь, крымка, менивая смерть, болезнь Святого Аазаря и Аругие - хроническое инфекционное заболевание, вызываемое микобактериями мепры, характеризующееся гранулематозными поражениями кожи, слизистых верхних дыхательных путей и периферической нервной системы, а при несвоевременной диагностике - вовлечением в процесс костно-мышечного аппарата, органа зрения и внутренних органов [9].

Времена изменились и за окном уже XXI век, но... ореол страшной славы вокруг болезни не исчез. Многие Аюди или вообще ничего не знают о мепре, или ограничиваются сведениями из художественной митературы, как средневековой, так и относящейся к XIX - началу XX века, когда мепра изобража^ась в крайне устрашающем виде, а поведение окружающих здоровых мюдей сводилось к стремлению любыми средствами избежать встречи с "прокаженными". Справедливости ради стоит сказать, что не только обычные непросвещённые в медицине Аюди не имеют обширных знаний ни о мепре, ни о путях заражения ею, но и у многих врачей представление об этой инфекции иногАа не соответствует современному состоянию мепрологии.

В конечном счёте, это приводит к тому, что при встрече с больным мепрой зачастую у врача нет даже подозрения на это заболевание, а больной годами мечится от Аругих неАугов. 


\section{1. МОРФОАОГИЯ И КУАЬТУРААЬНЫЕ СВОЙСТВА}

Начало изучения мепры как инфекционного заболевания датируется 1874 г. (со времени открытия норвежским врачом G.A. Hansen возбудителя мепры -

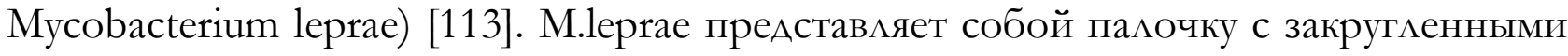
концами. Жгутиков и пилей не имеет. Размеры М.leprae колеблются от 1 до 5 мкм в Алину и 0,2-0,5 мкм в Аиаметре. Возбудитель мепры обладает полиморфизмом. Еще A. Hansen (1880) находил в препаратах из мепромы палочки различных размеров и форм, расположенные внутриклеточно группами параллельно Аруг Аругу (в виле “глоби”) (рис. 1). Возбудитель грамположителен, кислото- и спиртоустойчив (окрашивается по методу Циля-Нельсена в красный цвет). В препаратах из кожных поражений больных M.leprae встречаются, в основном, в виде Авух форм: гомогенной (равномерно окрашенные палочки) и зернистой (палочки, состоящие как бы из цепочки зерен) [16]. Вопрос о жизнеспособности и активности зернистых форм не раз дискутировался в печати. Некоторые авторы склоняются к признанию зернистых форм как Аегенеративных $[80,177]$. Таксономически M.leprae относятся к порядку Actinomycetales и семейству Mycobacteriaceae [59].

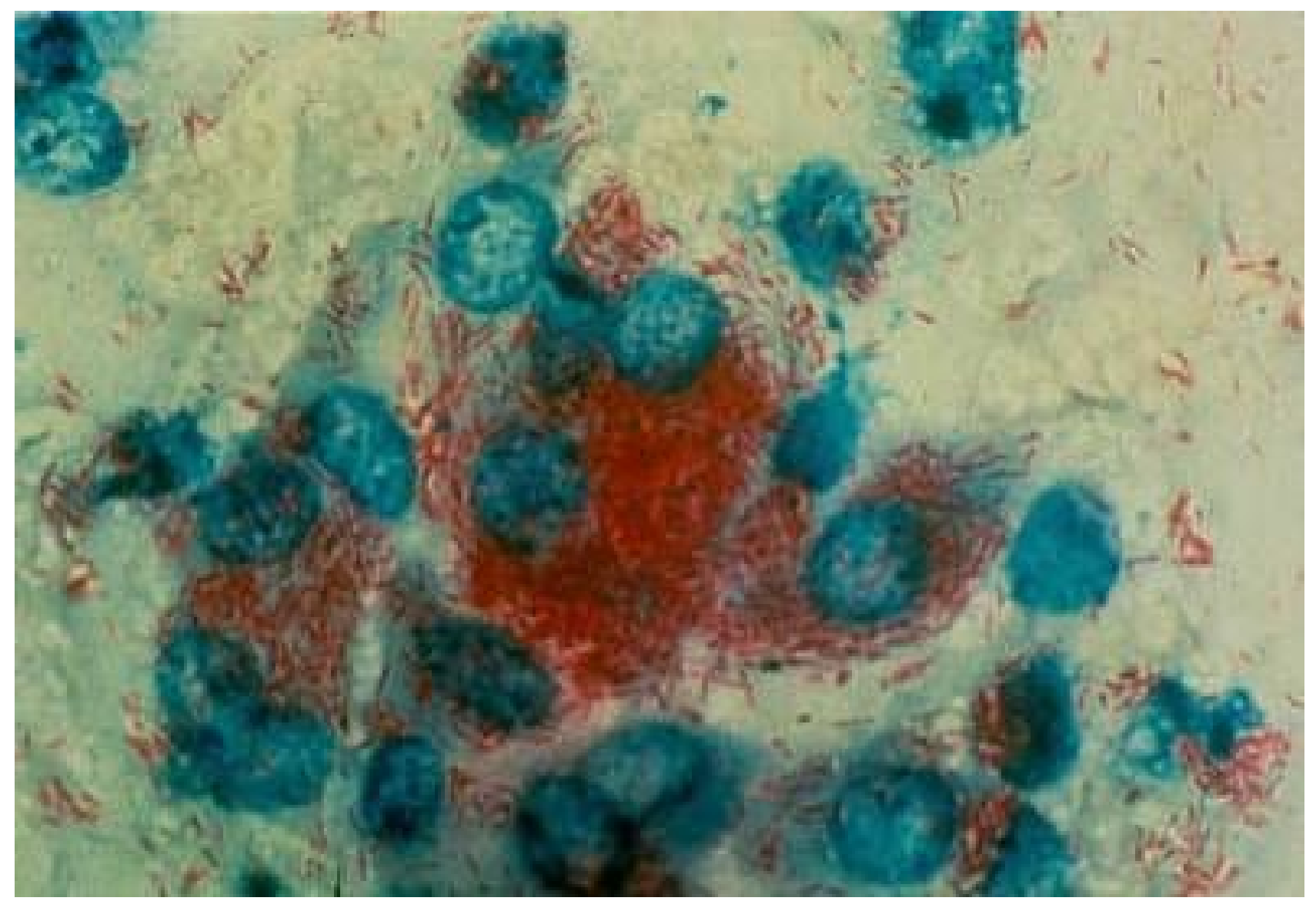

Рис. 1. Аепроматозный тип ^епры. Микобактерии мепры в гранулемах кожи больной К. Видны полиморфные клетки МА и в виде «глоби».

Окраска по Цилю-Нельсену. ×1700. 
Предполагая сложный цикл развития, который проходят M.leprae, ряА авторов допускают возможность существования L-форм [96, 117, 147, 148, 149 , 150], не окрашивающихся по методу Циля-Нельсена, кислотоподатливых форм [7, 18, 23, 34, 36, 71, 100] и фимьтрующихся «вирусоподобных» форм M.leprae [35, 135]. Спороподобные образования у M.leprae обнаруживали S.Sato (1968) и А.А. Ющенко (1970).

Поскольку многочисленные попытки исследователей получить общепризнанную культуру M.leprae на питательных средах различного состава и клеточных культурах не увенчались успехом, вопрос о культивировании M.leprae

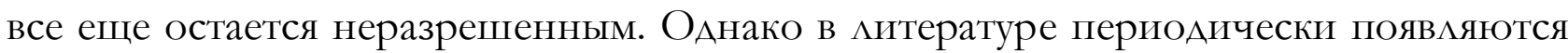
сообщения об успешном культивировании на искусственных питательных средах микобактерий, вылеленных непосредственно из инфицированных тканей больных мепрой мюдей $[97,86,168]$. В том числе в НИИА были получены и существуют до настоящего времени культуры микобактерий, выделенные от больных мепрой большинстве случаев авторы этих публикаций не могут воспроизвести результаты собственных экспериментов по культивированию. Кроме того, не всегда удается подтвердить принадлежность полученных культур к M.leprae.

Со времени открытия возбудителя мепры предпринимались многочисленные попытки заражения ими животных. В опытах использовались различные животные, птицы, рыбы, амфибии. Некоторые результаты были Аостигнуты при введении 5-10 тыс. клеток M.leprae в подушечку мапки мыши [165] (рис. 2). Через 8-12 мес. с момента заражения количество микобактерий увеличивалось. ОАнако микроорганизмы обнаруживались инокуляции и изредка в мышцах и соседних мимфатических узлах. 3.В. Бадовская с коллегами в НИИА одна из первых воспроизводили модель Шепарда в экспериментах на мышах [3, 44, 63, 68]. С разработкой этой модеми появилась возможность идентификации микобактерий по характеру их размножения в мапке и возможность испытания антибактериаАьной активности мекарственных среАств.
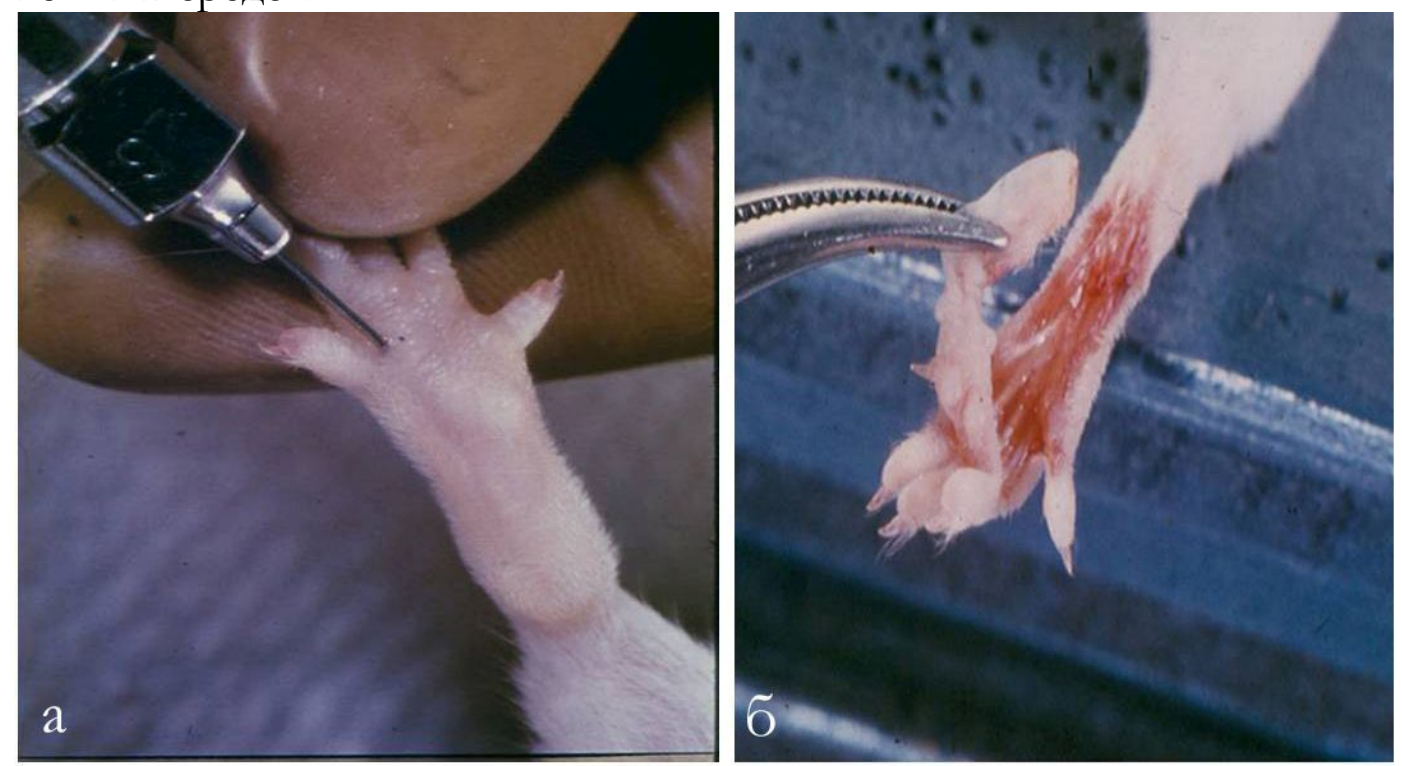

Рис. 2. Заражение М.leprae экспериментальных мышей (а). Забор патологического материала Аля исследования (Shepard C.C., 1960). 
В 1971 году W.F. Kirchheimer, E.E. Storrs сообщили об удачных опытах по заражению мепрой Аевятипоясного броненосца [129]. На этой модели стало возможным воспроизвести мепроматозный тип мепры и получить значительное количество микобактерий (рис. 3). С 1979 по 1985 гг. в НИИА проводились эксперименты на девятипоясных броненосцах. В ходе этих исследований впервые были получены кАинические и патоморфологические Аанные, свилетельствующие о том, что у зараженных M.leprae броненосцев могут развиваться реакции, аналогичные восходящим (реверсивным) реакциям у больных мепрой 14].

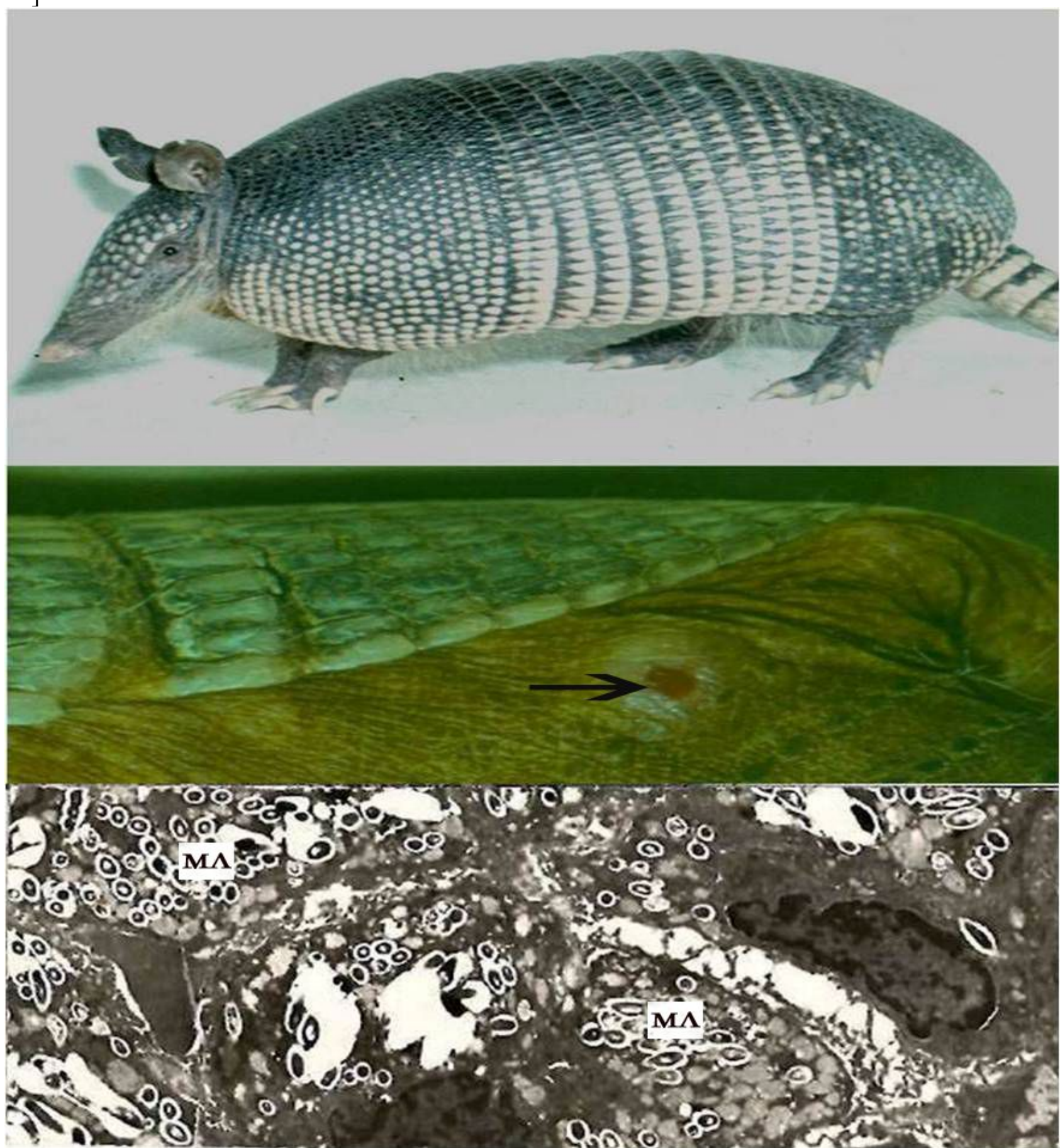

Рис. 3. Аевятипоясный броненосец. Аепрома кожи броненосца.

Электронно-микроскопическое исследование гранулемы $\times 10000$ 


\section{2. УАЬТРАСТРУКТУРА MYCOBACTERIUM LEPRAE}

\section{Методика электронно-микроскопического исследования}

Наиболее эффективные результаты дал метод ультратонких срезов и методы цитохимии и иммунохимии (выявление ферментов, гликозаминогликанов, антигенов M.leprae) [17]. Мы использовали также метод негативного контрастирования, который позволяет составить представ цение в целом, причем Аает возможность выявить детали наружной структуры микроорганизма. Заметим, что этот метоА применим только Аля культивируемых микроорганизмов.

Метол ультратонких срезов включает следующие этапы: фиксацию, обезвоживание, пропитывание материала в возрастающей концентрации этилового спирта, эпоксиАной смолы, заливку материала в эпоксиАные смолы и полимеризацию.

При использовании биоптатов мепром их предварительно измельчали Ао объема в $1^{3}$ мм. Культивируемые микобактерии предварительно центрифугировали 10 мин. при 1000 оборотов.

Смолы состав яяли по методу A.R. Spurr (1969).

Срезы получали на ультрамикротоме LKB 8802A (Швеция) толщиной 20-50 нм. Срезы монтировались на покрытые формваром пленки. Контрастирование срезов производицось насыщенным спиртовым раствором уранилацетата (при $56^{\circ} \mathrm{C}$ в течение 5-10 минут). И затем гилроокисью свинца по методy Reynolds [17]. При цитохимических исследованиях дополнительное контрастирование не проводицось.

Препараты изучали в электронном микроскопе Tesla BS-540 (Чехословакия) с разрешающей способностью 0,7 нм.

Первое сообщение об электронно-микроскопическом исследовании M.leprae датируется 1948 г. [90]. В то время исследователям удалось выявить Аишь оболочку M.leprae и полярно расположенные плотные тельца, которые они ошибочно принима^и за ялра микобактерий. На раннем этапе изучения M.leprae с помощью электронного микроскопа, при отсутствии специацьных методов препарирования, авторы изучали целые клетки мепромы человека, освобожденные от тканей путем центрифугирования, Аибо соскоб или скарификат с пораженной кожи больных мепрой. Обобщая вышеперечисленные результаты, следует отметить, что все авторы отмечают полиморфизм M.leprae, вакуоли и электронноплотные гранулы в цитоплазме.

Начиная с 1958 года исследованиями Т. Yamamoto et al. [180], впервые применившими метоА ультратонких срезов к изучению внутренней структуры M.leprae, ряд отечественных и зарубежных авторов разработали общие положения относительно основных структурных компонентов возбудителя мепры. ОАнако были нередки и спорные моменты. Так, наружный умеренно электронно-плотный слой определими побочно Т. Hirata, T. Nakayama (1975), трактуя его как «наружныци капулярный слой бактериальной клетки». В то же время нет упоминания о существовании подобного слоя в работах Аругих авторов, изучавших ультраструктуру M.leprae. Существование умеренно электронно-плотного наружного слоя ими отрицается. Методом напыления хромом или платиной- 
палцадием было показано, что наружная поверхность клеток M.leprae имеет виА сети из ментовиАных или нитевидных возвышений и состоит из парных фиброзных структур [144] пептиАогликолипиАной природы [107]. В работах, посвященных изучению ультраструктурных особенностей Аругих микобактерий [2, 24, 32], авторы называют подобный слой как «микрокапула» осмиофильный материал». Впервые микрокапсула M.leprae на ультраструктурном уровне выявлена и илентифицирована как поверхностный слой, состоящий преимущественно из гликозаминогликанов, в 1982 году [51] (рис. 4).

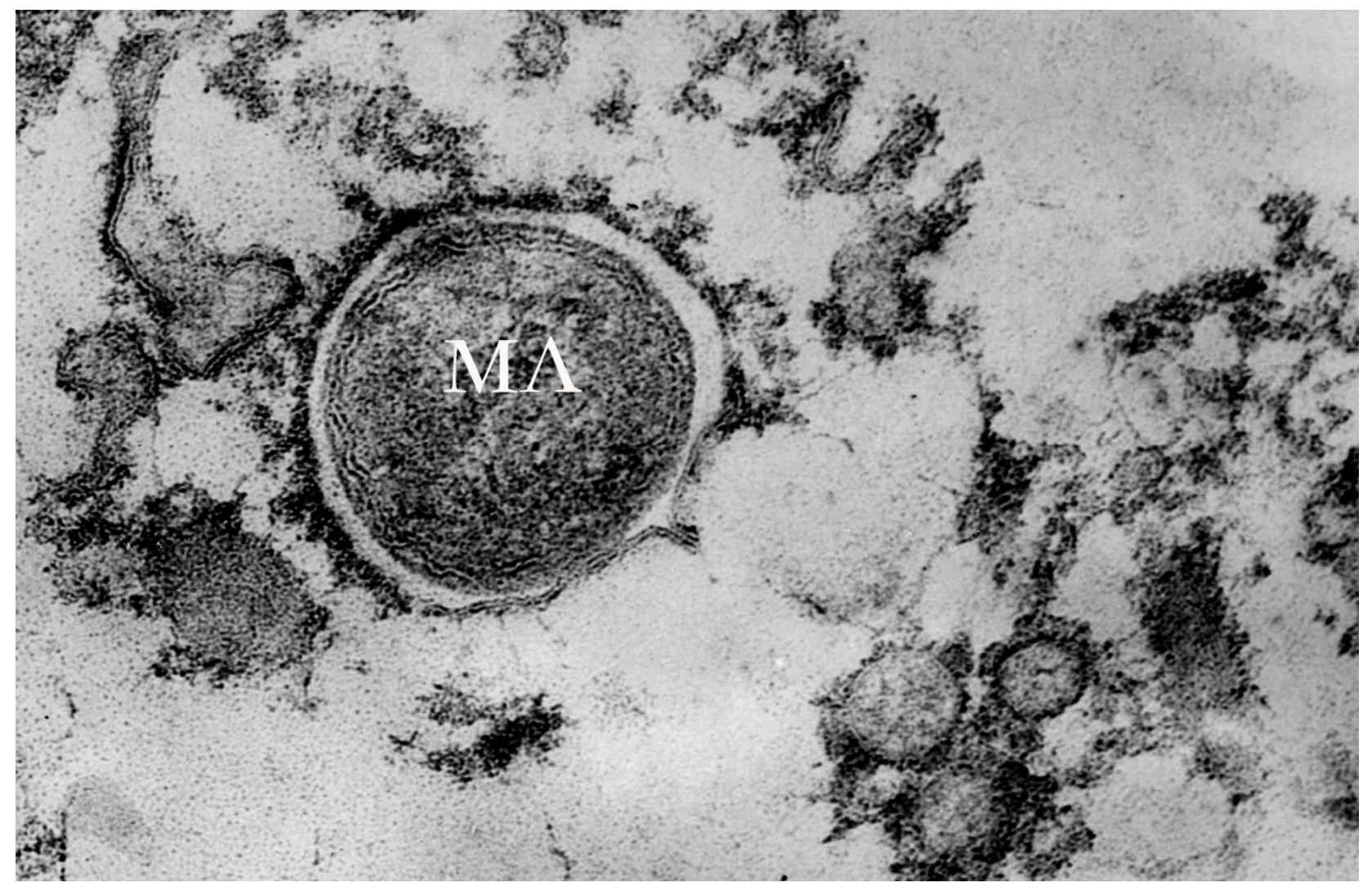

Рис. 4. Микрокапсула M.leprae. Окраска рутениевым красным. ×20000

Кислые мукополисахариды, обеспечивая связь клеток межАу собой, в то же время являются первым барьером на пути веществ, проникающих в клетку. Микрокапсула значительной толщины была обнаружена у микобактерий мепры от больных, Алительно и безуспешно мечившихся специфическими препаратами. Поэтому, яв яясь наружным структурным компонентом микобактериальных клеток, микрокапсула в значительной мере определяет характер взаимоотношений возбудителя мепры с клетками макроорганизма и, как предполагается, препятствует внутриклеточному перевариванию M.leprae, способствуя развитию мекарственной устойчивости [51] (рис. 5). МежАу вышеупомянутым слоем и электронно-плотной частью клеточной стенки располагается равномерный электронно-прозрачный слой, имеющий толщину 5-15 нм $[51,80,121]$. Он одинаков по толщине по всему периметру бактериальной клетки и вплотную примыкает к слоям клеточной стенки. 


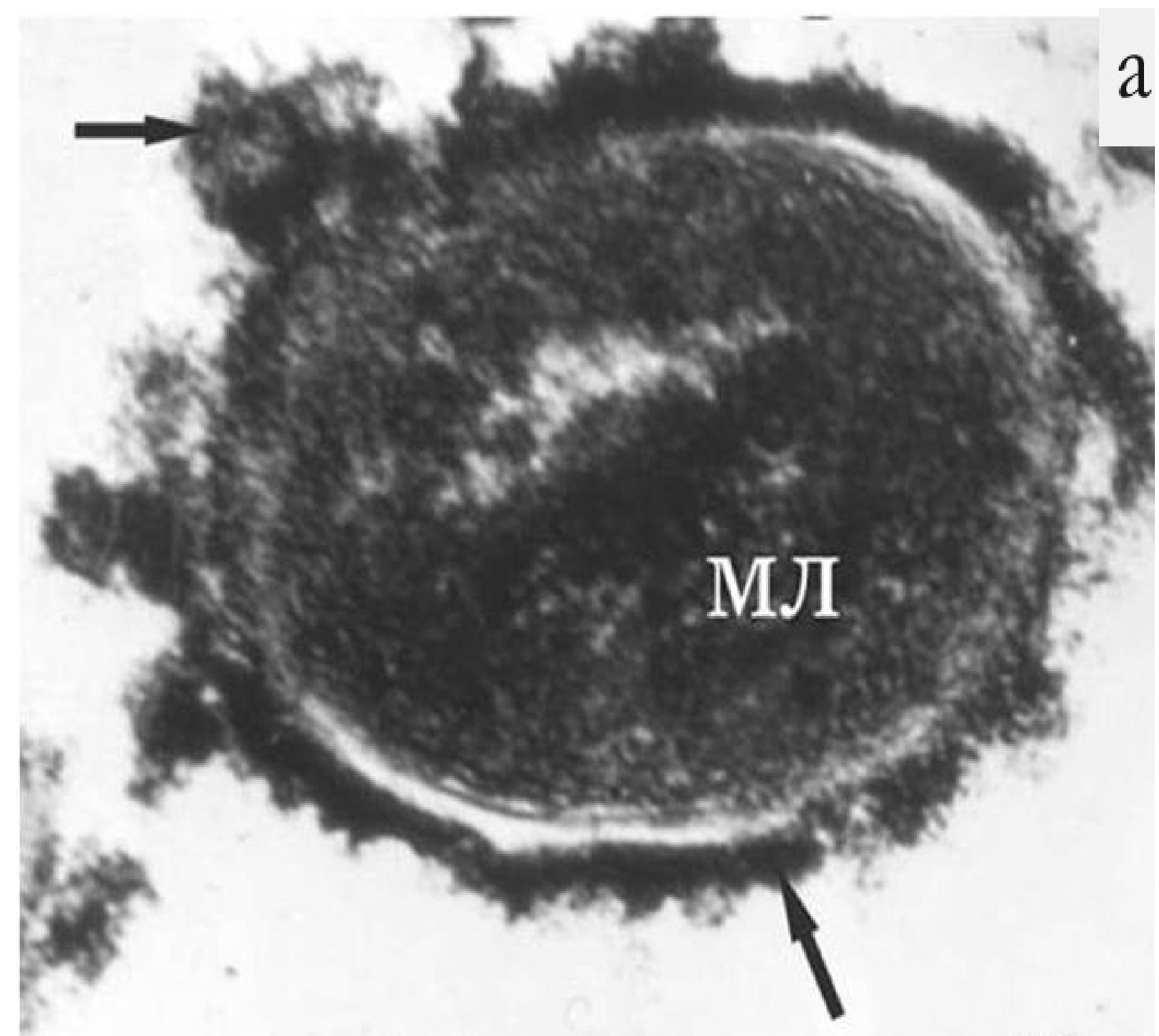


Электронно-плотная часть клеточной стенки представляет собой одноконтурное образование, толщиной 3-10 нм. На электронограммах мизированных микобактериальных клеток было отмечено расщепление электронно-плотной части клеточной стенки на два электронно-плотных слоя $[51,80]$ (рис. 6а).

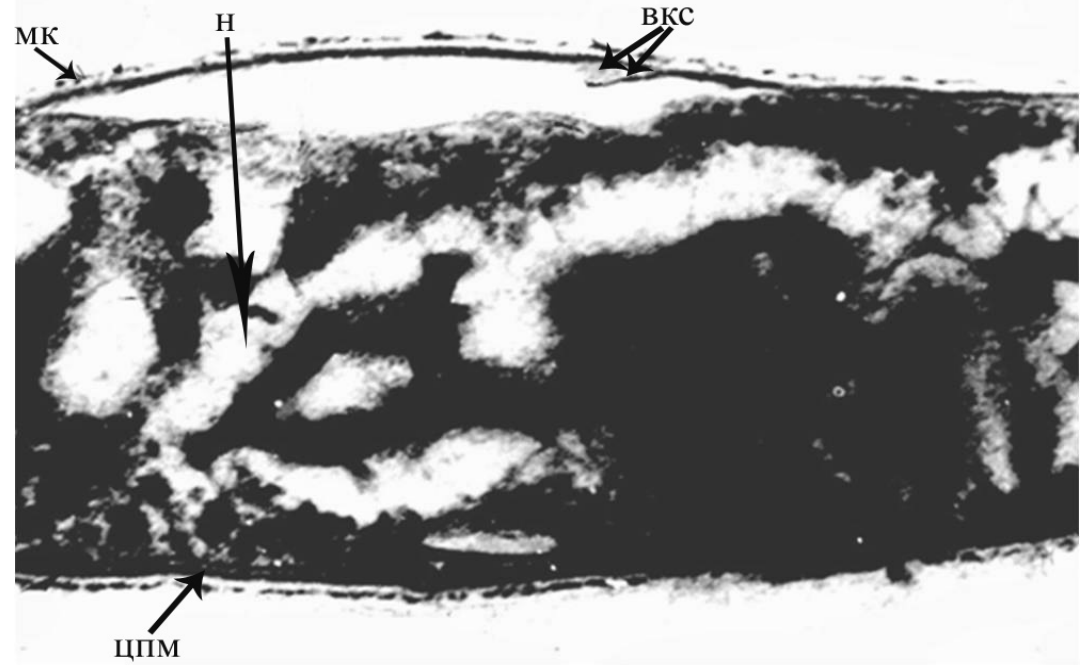

Рис. 6 а. Микобактериальная клетка. Расщепление электронно-плотной части клеточной стенки на Ава электронно-плотных слоя. $× 25000$

Клеточная стенка является наиболее прочным образованием, хорошо сохраняющимся внутри клеток мепромы Ааже при полном мизисе цитоплазмы микобактериальных клеток (рис. 6б).

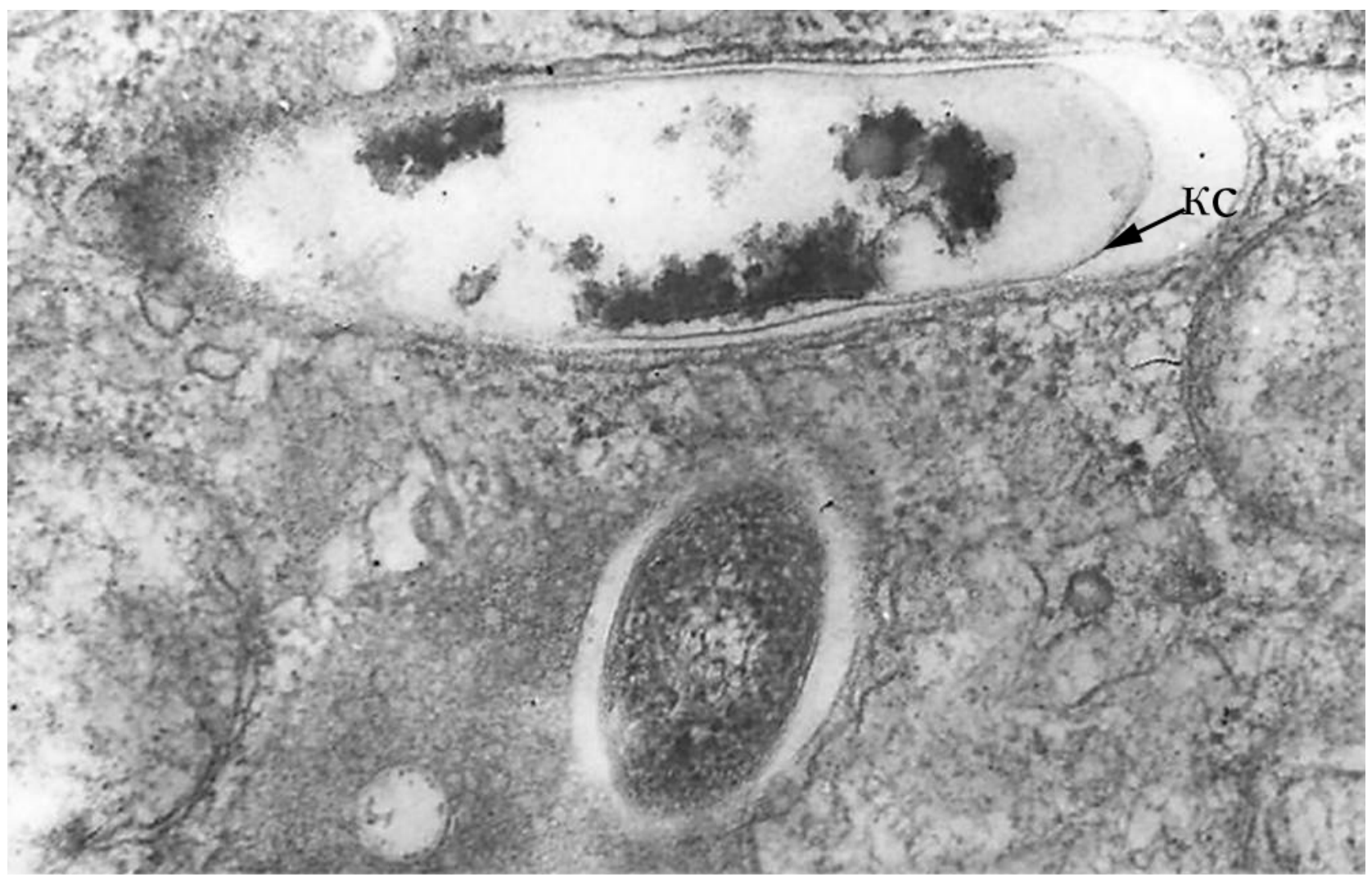

Рис. 6 б. Сохранение клеточной стенки даже при полном Аизисе цитоплазмы M.leprae. $\times 20000$ 


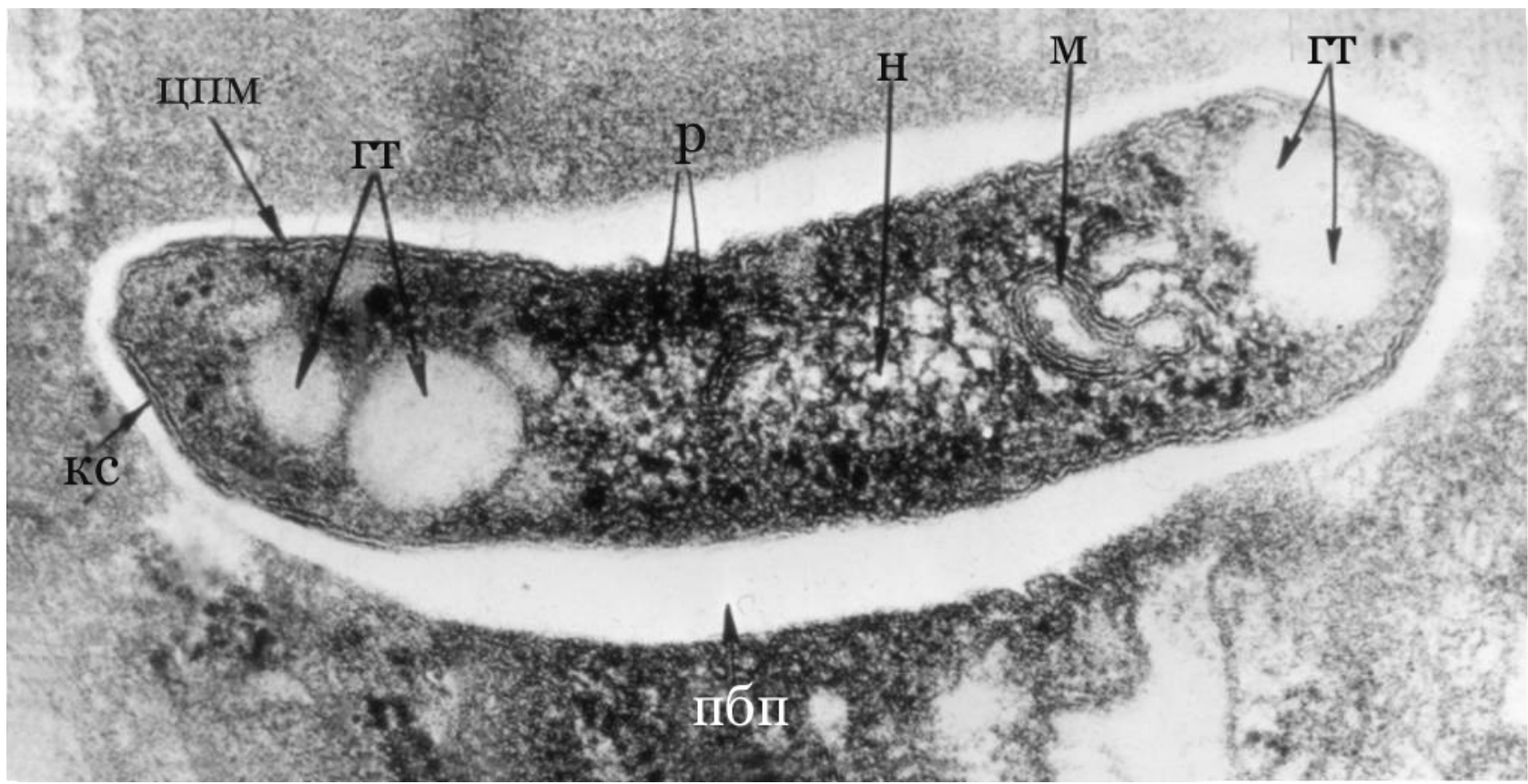

Рис. 7. M.leprae. Видна трехслойная цитоплазматическая мембрана. ×20000

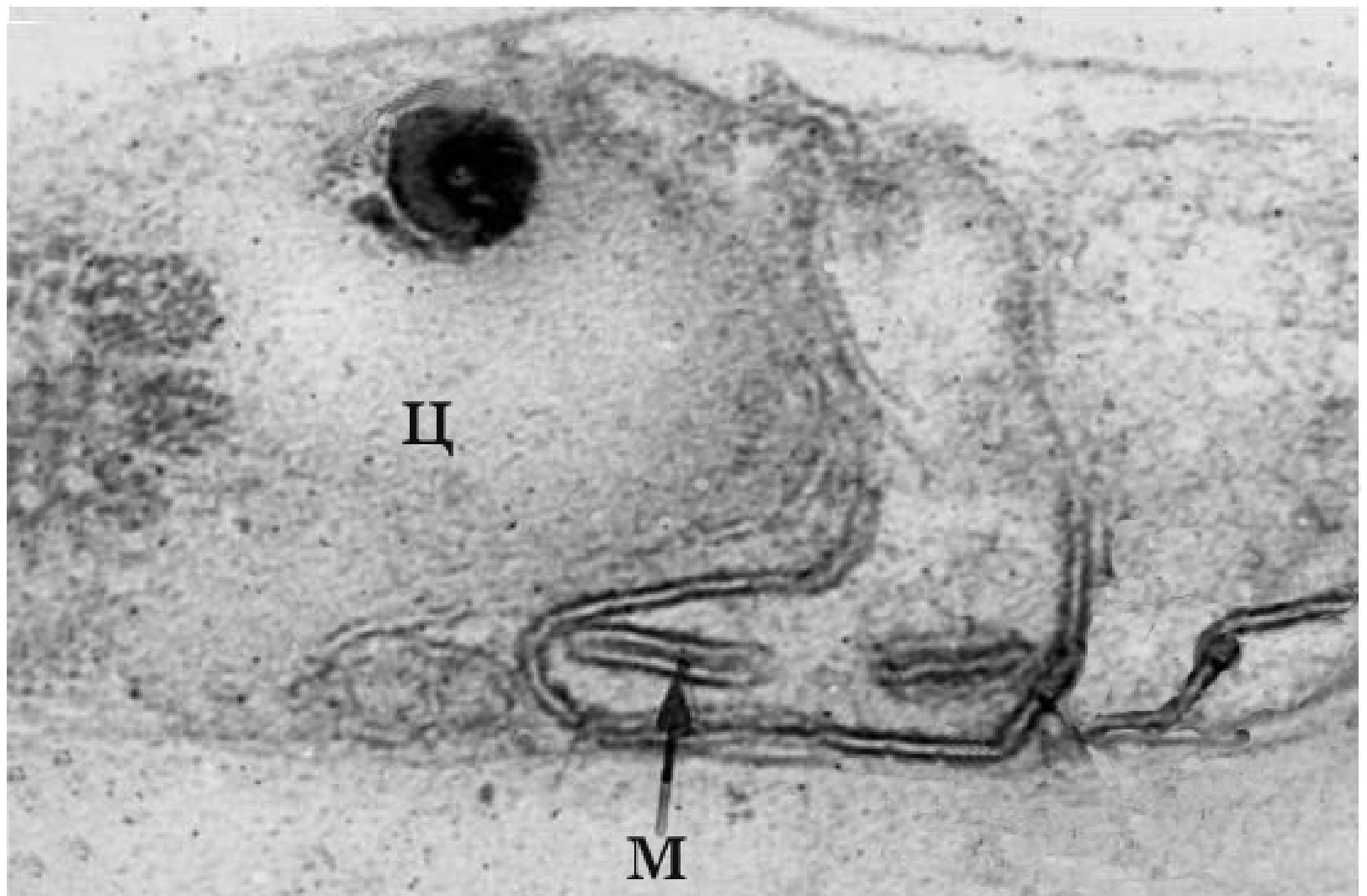

Рис. 8. Мембранный аппарат микобактериальной клетки. Мезосома п^астинчатой конфигурации. $\times 25000$

КАеточные стенки сохраняют форму микобактерий, что говорит о большой устойчивости их материала к химическим воздействиям [80]. К клеточной стенке вплотную примыкает наружный слой цитоплазматической мембраны. Цитоплазматическая мембрана трехслойна и состоит из Авух электронно-плотных слоев, разделенных средним электронно-прозрачным [51, 80, 120, 121]. Толщина 
каждого слоя составляет примерно 2,5-3 нм. ОАнако М. Nishiura и др. (1969) утверждают, что цитоплазматическая мембрана однослойная, а видимую трехслойность образуют парные фиброзные структуры поверхностных слоев. С Аругой стороны, трехслойность цитоплазматической мембраны прослеживается и при ее отслоении от клеточной стенки, и в месте перехода ее в мезосому [51, 80], что говорит о том, что все три слоя цитоплазматической мембраны преАставляют собой целостное образование (рис. 7).

Инвагинируя внутрь цитоплазмы бактериальной клетки, цитоплазматическая мембрана образует внутрицитоплазматические структуры мезосомы, которые вместе с цитоплазматической мембраной составляют мембранный аппарат микобактериальной клетки (рис. 8, 9).

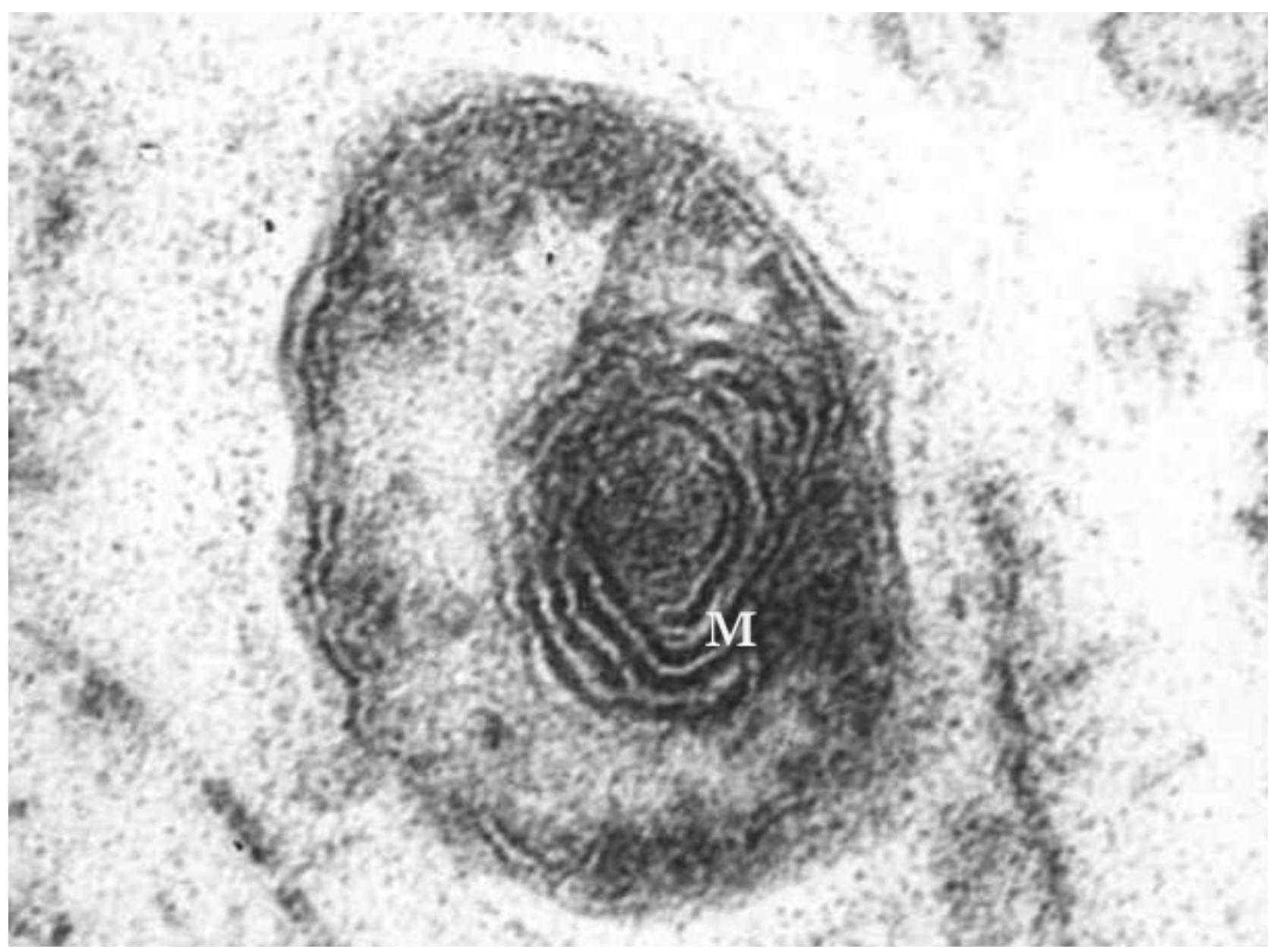

Рис. 9. Мембранный аппарат микобактериальной клетки.

Мезосома петлевиАной конфигурации. $\times 25000$

По виду в пространстве мезосомы различаются на пластинчатые, гроздевидные, везикулярные, трубчатые, петлевилные [80, 93, 163]. Мезосомы МА имеют отношение к метаболизму и исчезают с первыми признаками дегенерации микобактериальной клетки $[93,121]$. Располагающийся в центре клетки нуклеоиА (Рис. 10) не ограничен мембраной и на ультратонких срезах предстает в виле электронно-прозрачной зоны с заключенными внутри ее нитевидными структурами АНК $[51,80,180,120]$. 


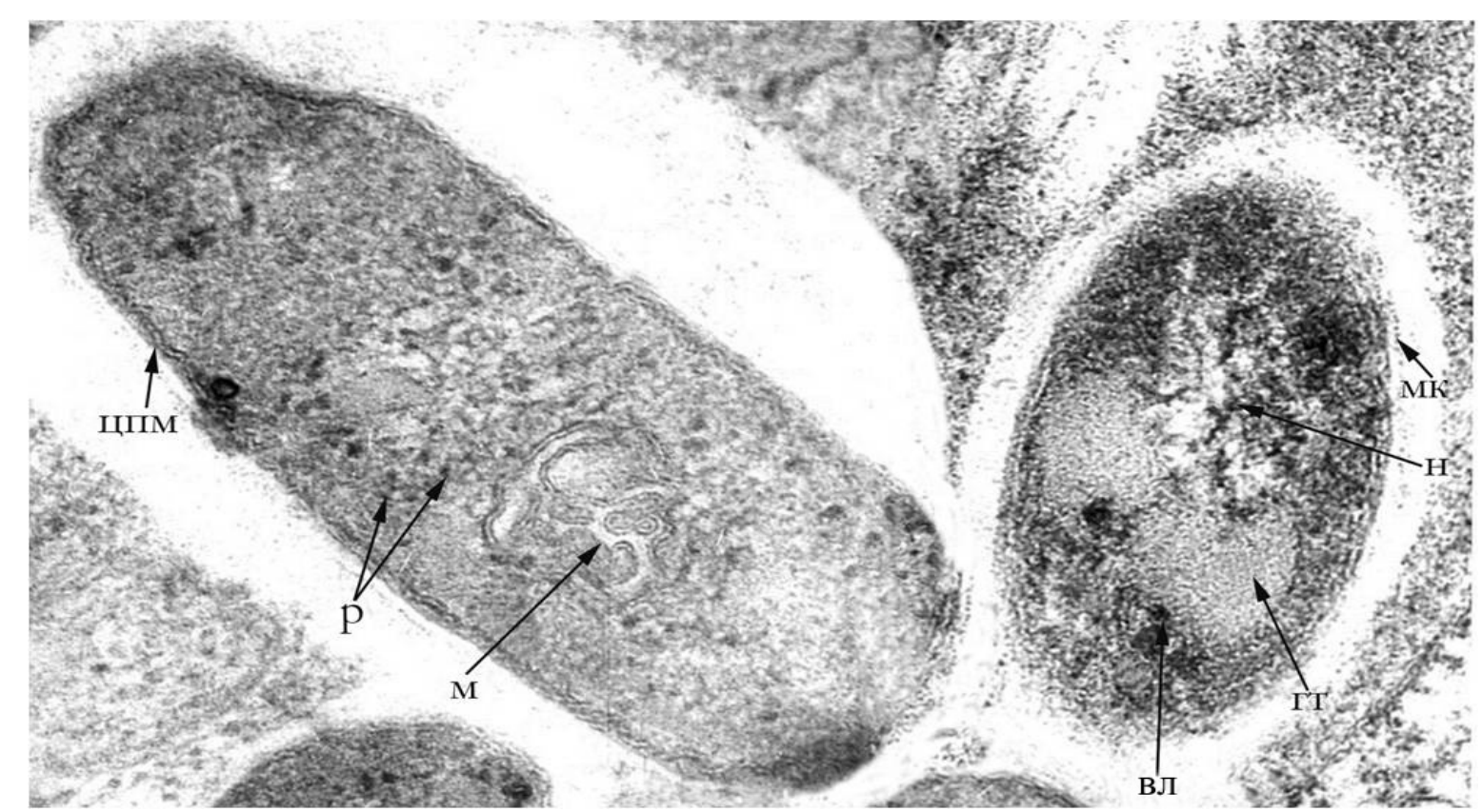

Рис. 10. Mycobacterium leprae. Включения в цитоплазме. ГТ, В $\Lambda$, Р, М петлевиАной конфигурации. $\times 20000$

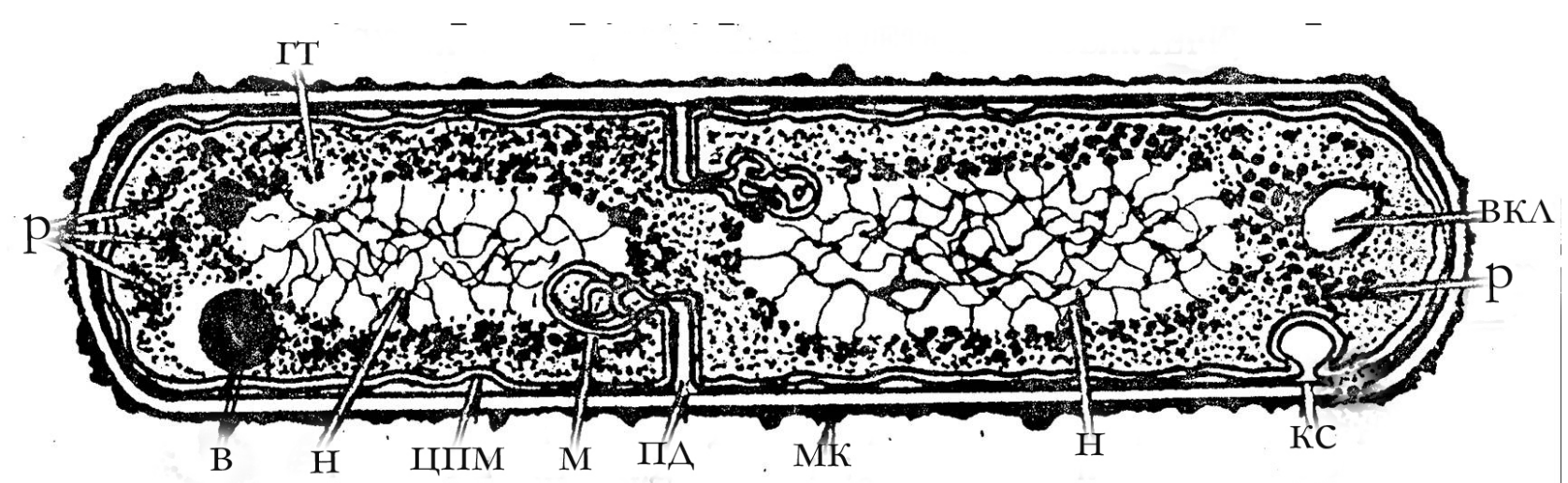

Рис. 11. Микобактерия мепры. Включения в цитоплазме МК, КС, ЦПМ, Н, М, p, ГТ, В, ВКА, ПА. (схема)

Расположенная межАу цитоплазматической мембраной и нуклеоидом цитоплазма микобактериальной клетки содержит немногочисленные мезосомы и включения: рибосомы и полирибосомы, сферические умеренно электронно-плотные гранулы Аиаметром 20-50 нм, округлые или овальные гранулы диаметром 0,1-0,2 мкм с меньшей электронно-оптической плотностью, чем окружающая их цитоплазма и электронно-прозрачные вакуоли, окруженные мембраной [51, 80, 146, 163] (рис. 7, 10, 11). S. Sato (1968) связывает образование умеренно электронно-плотных гранул с клиническим статусом организма-хозяина, поскольку автор обнаруживал их, в основном, из свежих мепром.

Основной способ размножения M.leprae - леление путем инвагинирования внутрь цитоплазмы цитоплазматической мембраны [51, 80, 104] (рис. 12а).

В местах образования перегородки деления обнаруживаются мезосомы, связанные с перегородкой (рис. 12а) и нуклеоилом, которые принимают участие в формировании перегородки и синтезе материала клеточной стенки [51, 80, 116 , 117] (рис. 12 б). 


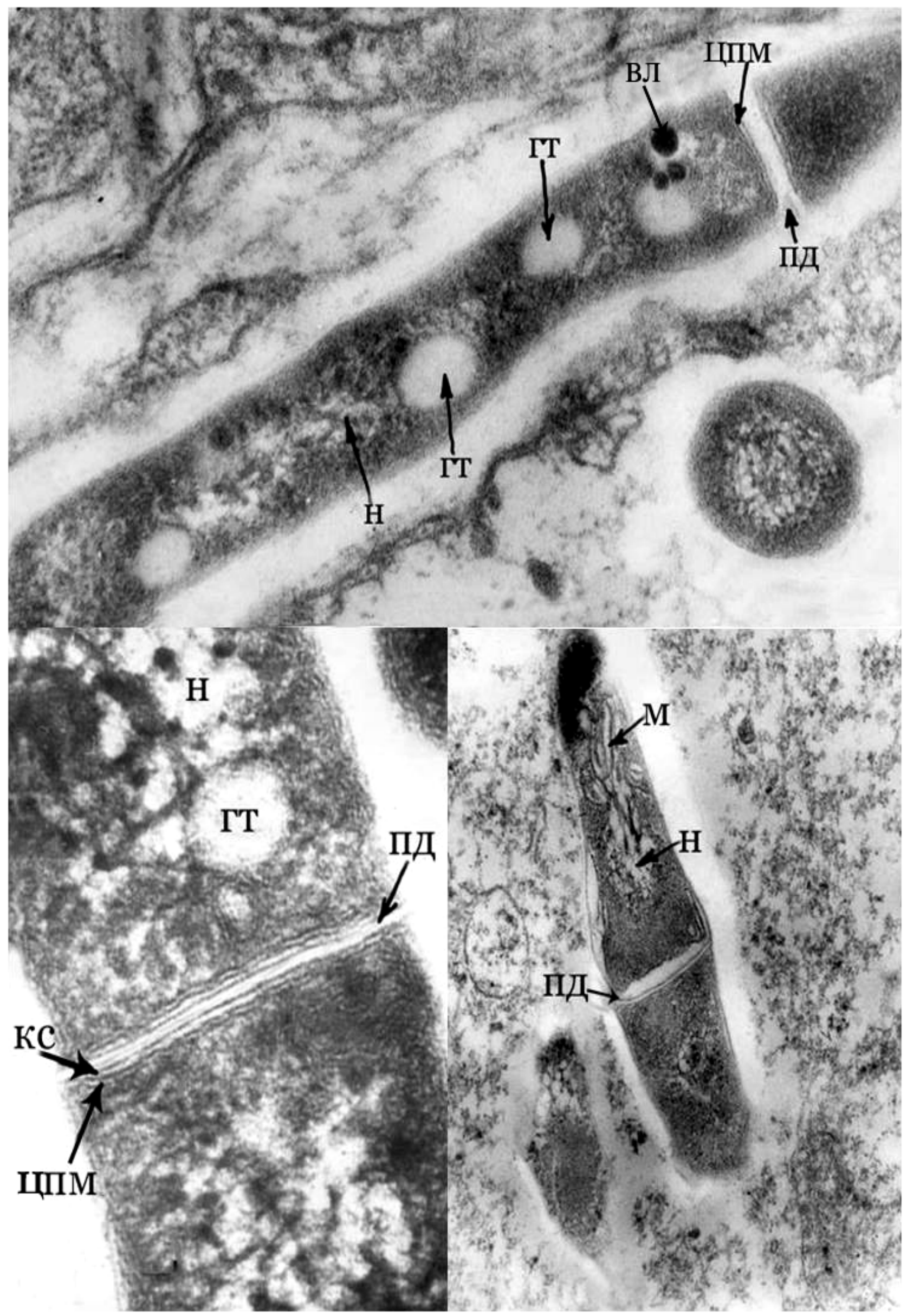

Рис. 12 а. Аеление Mycobacterium leprae. $× 20000$ 


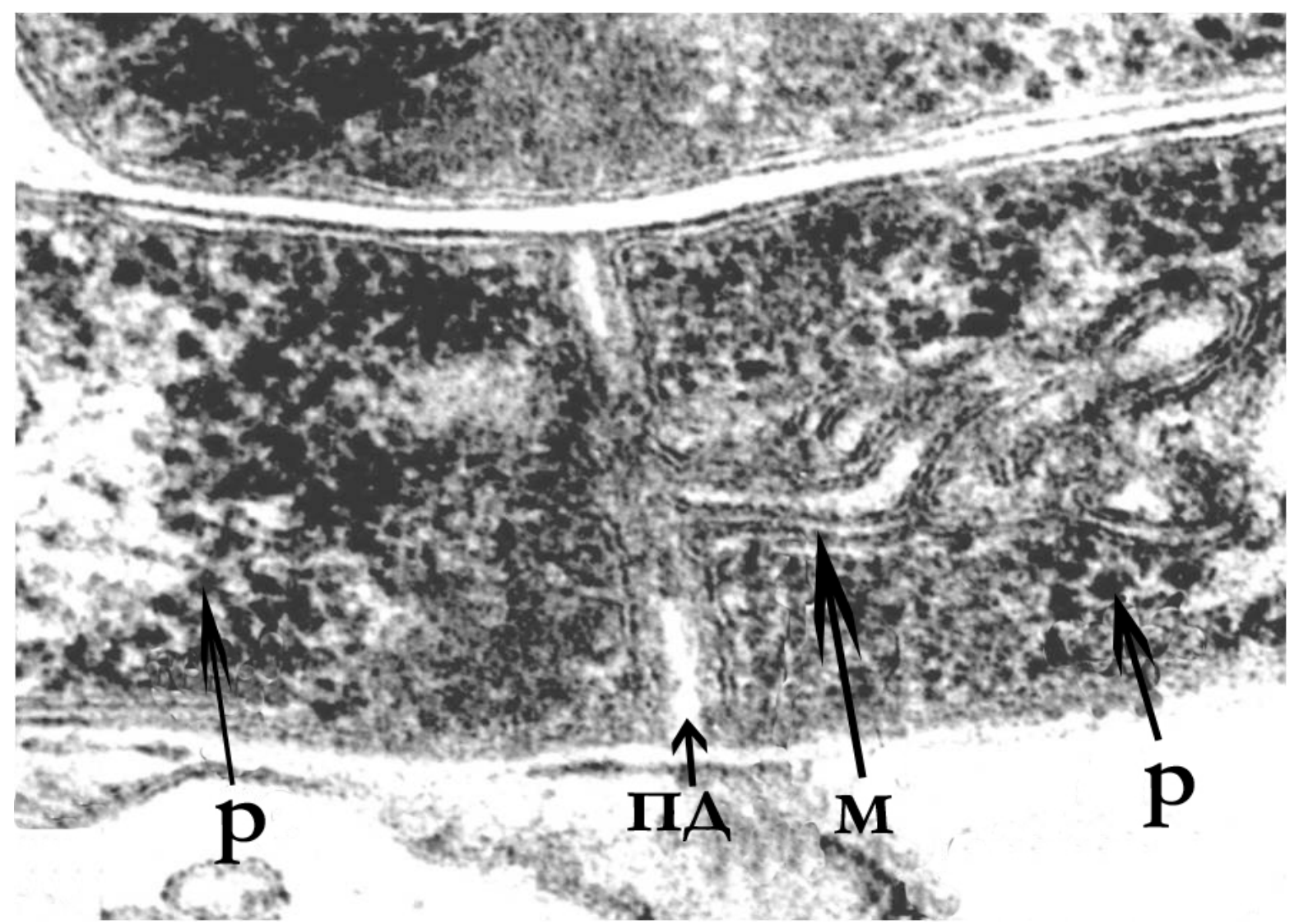

Рис. 12 б. Аеление Мусоbacterium leprae.Связь мезосом с перегородкой деления. $\times 25000$

В препаратах авторы отмечают, в основном, Аве формы микобактерий мепры: нормальную (гомогенную), сохраняющую обычную ультраструктуру бактериальной клетки, и Аегенеративную (рис. 13), с разрушенной цитоплазмой [139]. T. Imaeda [175] предполагает существование фильтрующихся форм, а T. Hirata и Т. Nakayama (1975); Y. Pares (1970, 1972, 1973, 1974) - L форм M. leprae.

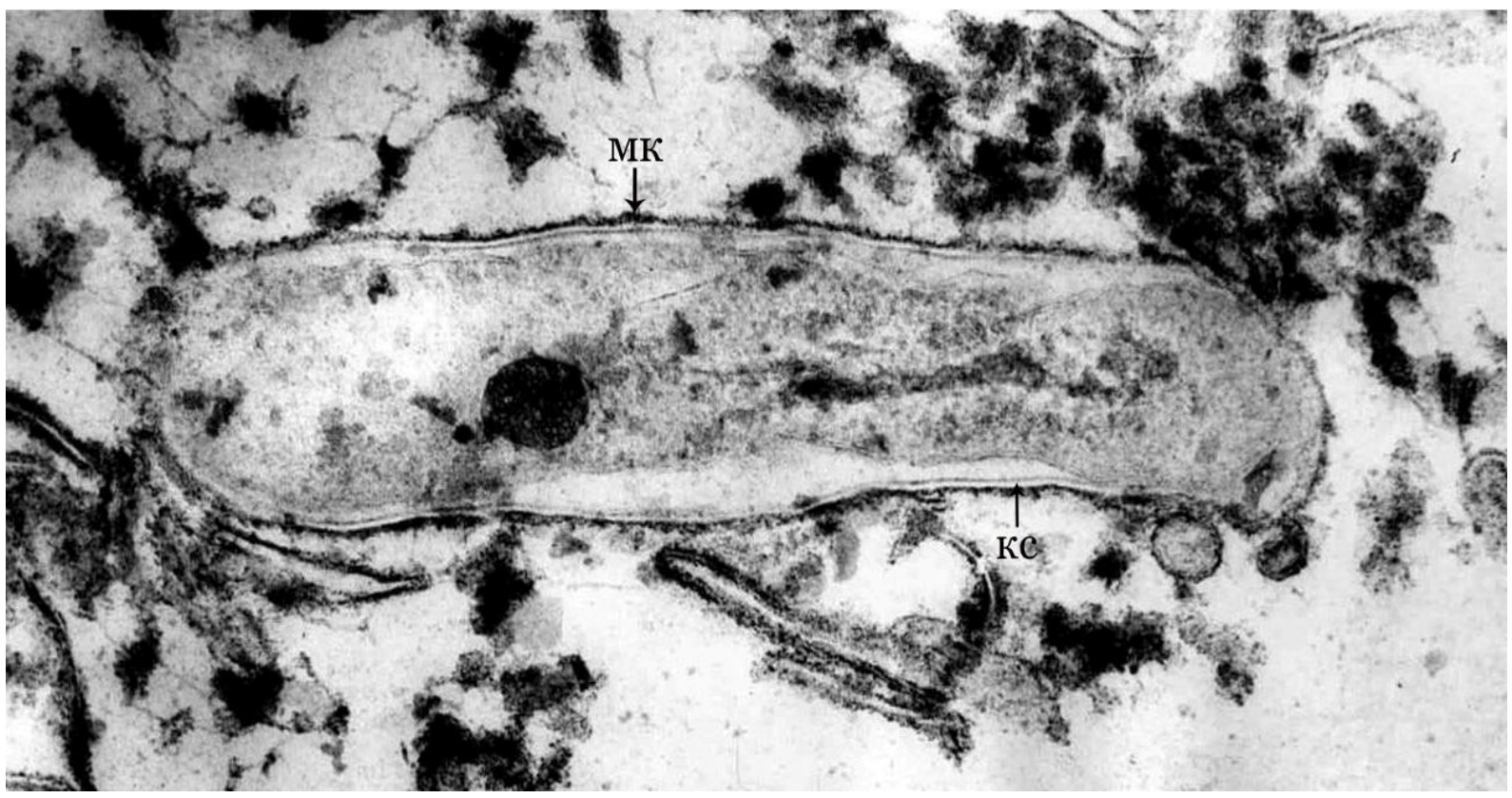

Рис. 13. Аегенеративная форма Mycobacterium leprae. $× 20000$ 
В материале от меченых больных с сульфонорезистентным течением заболевания в Аегенерирующих микобактериях обнаружены округлые или овальные ограниченные участки цитоплазмы, окруженные мембраной, которые напоминали образующиеся споры [80] (рис. 14a, 14б).

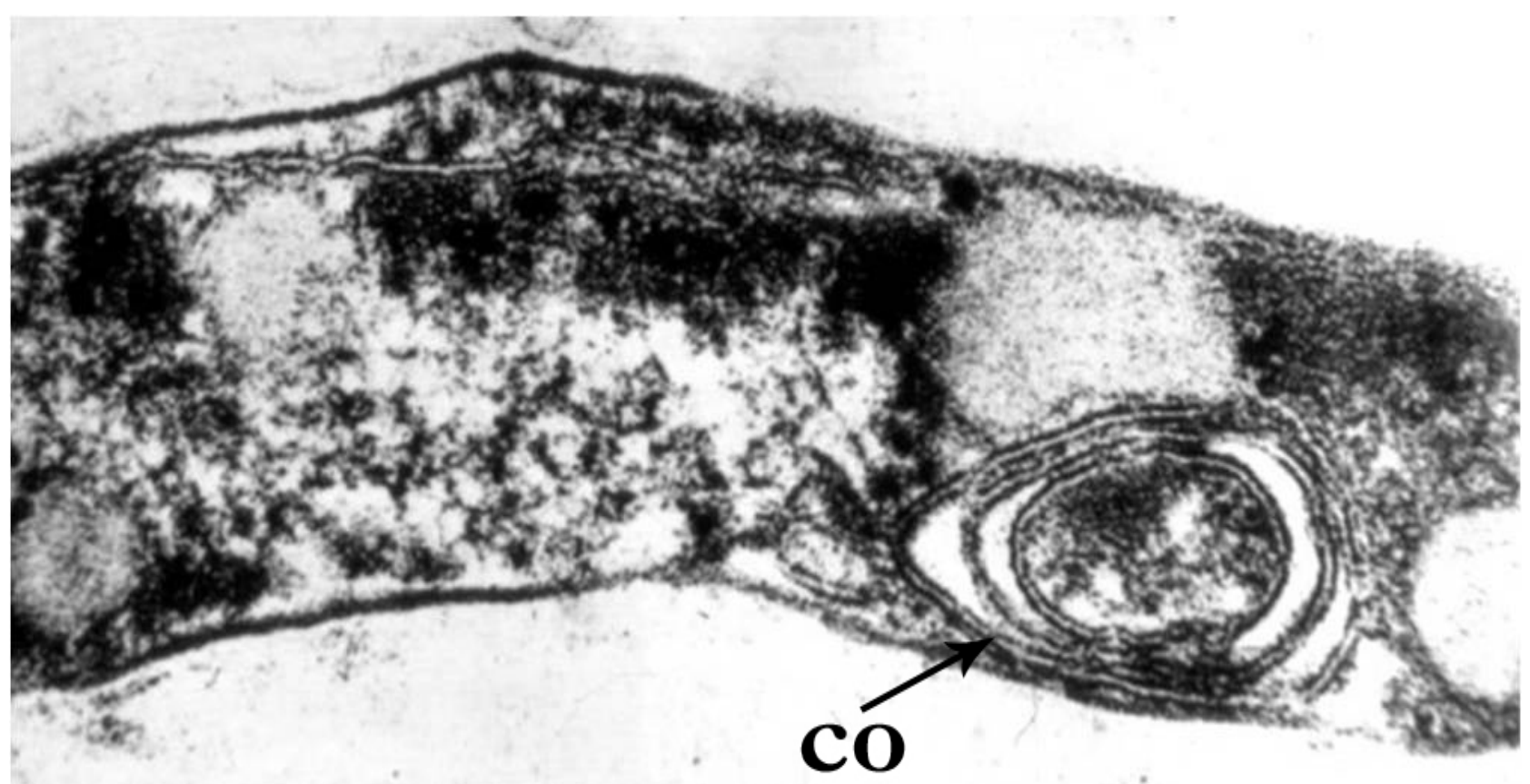

Рис. 14 а. Спороподобное образование Mycobacterium leprae.×20000

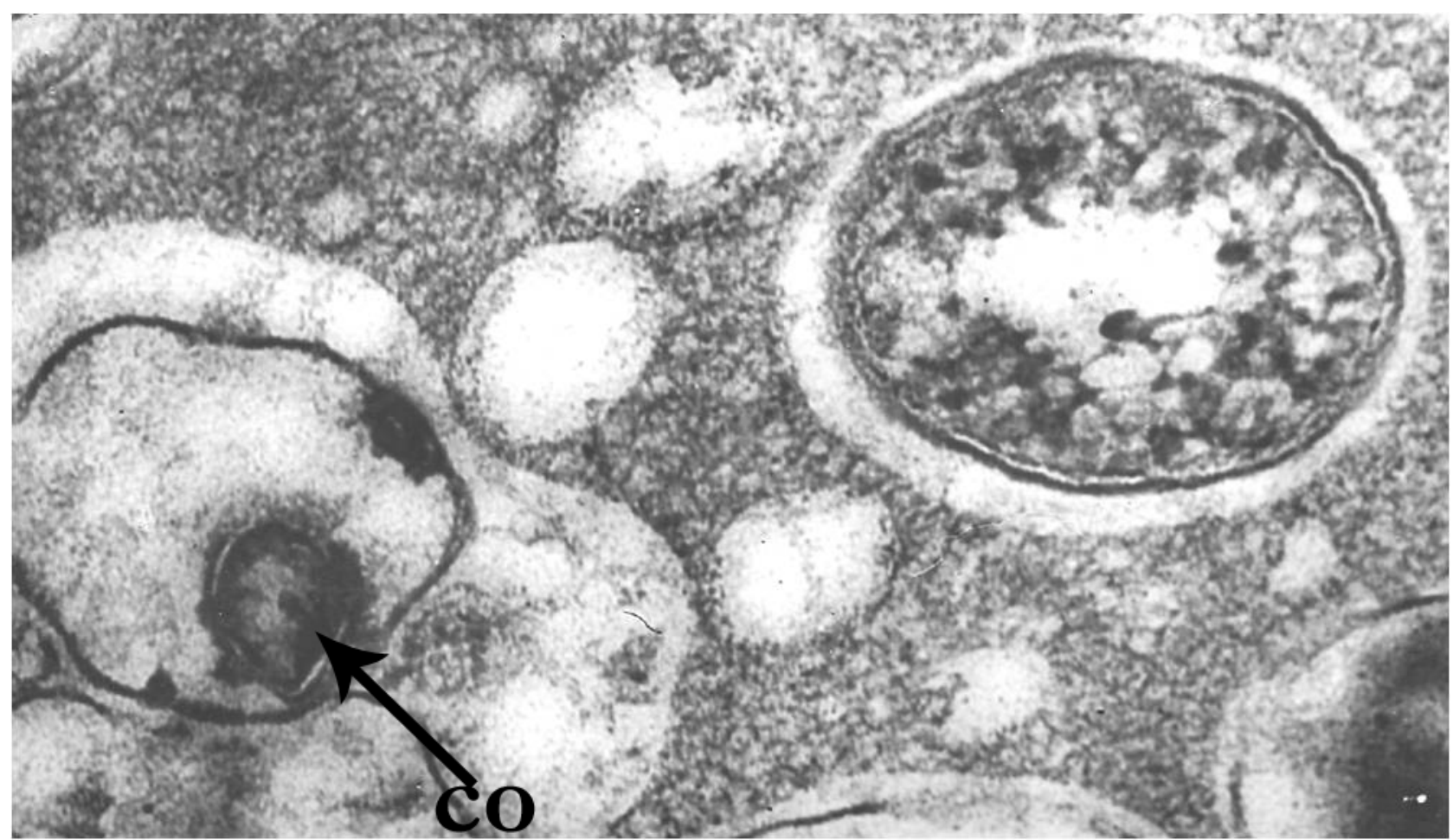

Рис. 14 б. Спороподобное образование Mycobacterium leprae (по А.А. Ющенко). $\times 20000$ 
Интересен вопрос о роли электронно-прозрачных зон вокруг M.leprae. J.H. Hanks (1961) считац их капсулами бактерий. Позже T. Imaeda, J. Convit (1962), проводя электронно-микроскопическое исследование, отвергли наличие у M.leprae толстых капсул и продемонстрировали на поверхности микобактерий мепры тонкий электронно-прозрачный слой, который Т. Imaeda, M. Ogura (1963) отнесли к клеточной стенке (рис. 7).

По поводу происхожАения электронно-прозрачных зон нет единого мнения. Так, J.M. Allen et al. (1965) показали, что M.leprae в начацьном периоде паразитирования находятся в очаге, Аающем положительную реакцию на кислую фосфатазу, и высказали предположение, что мизосомальные ферменты в таком очаге могут переваривать расположенный в нем материал, но при этом не оказывая никакого воздействия на микобактериальные клетки. После переваривания субстанции M.leprae оказываются в электронно-прозрачном пространстве, окруженном мембраной. P. Draper, R.J.W. Rees (1973), изучая под электронным микроскопом негативно окрашенные или обработанные методом замораживания-травления препараты кепромы крыс, обнаружили, что часть или

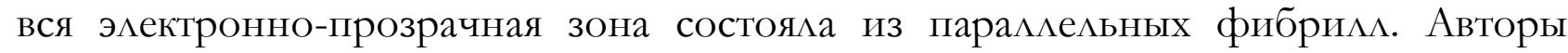
показали, что эти фибримлы содержат пептидогликолипиА, который, как они предполагали, образует капсулы микобактерий, защищающие их от мизосомальных ферментов клеток-хозяина. Т. Hirata, T. Nakayama (1974) предположили, что электронно-прозрачная структура вокруг M. leprae содержит остатки бактериальной клетки. Авторы обнаружили, что после образования

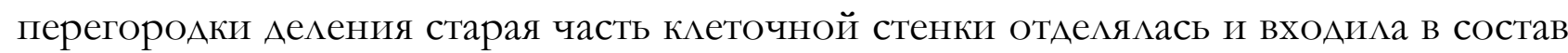
«перибактериального пространства». T. Imaeda, J. Convit (1962), А.А. Ющенко (1970) также предполагали бактериальное происхожАение электронно-прозрачных зон. При этом возникает вопрос: выполняют ми эти образования функцию капсул микобактерий, на что указывали P. Draper, R.J.W. Rees (1973), мибо являются скоплениями метаболизма микобактериальных клеток. 


\section{3. ЭАЕКТРОННО-ЦИТОХИМИЧЕСКОЕ ИЗУЧЕНИЕ MYCOBACTERIUM LEPRAE}

Разработка электронно-микроскопических исследований Аала много ценного как при изучении клеток организма, так и при изучении возбудителей различных заболеваний. ОАнако изучение объектов в электронномикроскопическом изображении представляет определенные трудности: объекты неподвижны, и без применения функционаАьных методов исследований значение структур трудно определить. Поэтому нами использовались Аополнительно методы электронной цитохимии и иммунохимии. Это позволяет оценить функциональную роль структур.

Э^ектронно-цитохимическое изучение микобактерий мепры началось с 1958 года, когда K.R. Chatterjeе, изучая при помощи электронного микроскопа целые клетки M.leprae, предварительно обработанные солями тетразолия, обнаружиц отложения формазана в так называемых «полярных гранулах», что Аало автору возможность преАположить наличие у микобактерий мепры ферментов цикла Кребса. ОАнако, поскольку работа проведена без применения метода ультратонких срезов, судить о том, в каких структурах бактериальной клетки мокализовался продукт реакции, практически невозможно.

Обычными биохимическими методами, используя разАичные методы очистки М. leprae от тканей, были выявлены следующие ферменты: цитохромоксидаза, пероксидаза, сукцинатдегилрогеназа, $\gamma$-глютамилтрансфераза, АОФА-оксидаза, мактатлегилрогеназа, рибулозодифосффатредуктаза, фолатсинтетаза, Аегидрофолатредуктаза, $\beta$-глюкуронидаза, супероксилАисмутаза, каталаза, фосфорибосицтрансфераза, малатоксилаза [151].

Выявление ферментов в бактериях, вылеленных из клеток, требует более строгого контроля, чем в бактериях, собранных из свободно растущих культур. Медленный распаА инкубируемых с бактериями определенных субстратов, используемых Аля выявления ферментов, возможно, обусловлен не бактериальными ферментами. М. lергае могут получать богатые энергией вещества непосредственно из клеток-хозяина и, вследствие этого, не содержать нормального набора ферментов, имеющихся у свободно живущих микроорганизмов [151]. Поэтому методы электронно-микроскопических исследований совместно с методами электронной цитохимии и иммунохимии могут Аать много ценных сведений о биологии М. leprae.

Эмектронно-цитохимическими методами [51, 54] показано наличие на цитоплазматической мембране и мезосомах M.leprae продукта цитохимических реакций, что свидетельствует о наличии в этих структурах основных окислительно-восстановительных ферментов: пероксидазы, цитохромоксидазы, НАА-Н-диафоразы и сукцинатдегидрогеназы (рис. 15). 


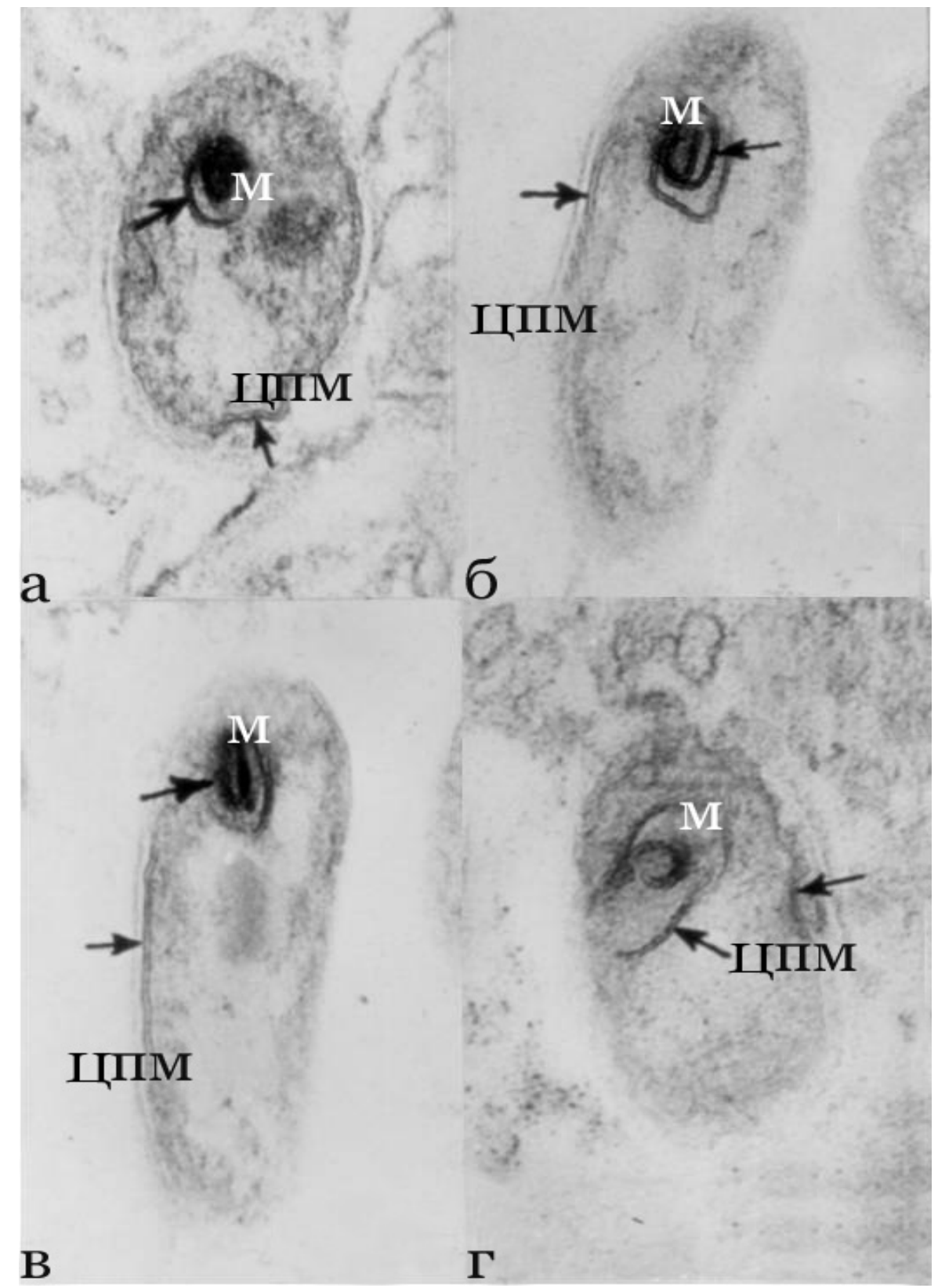

Рис. 15. Ферменты Мусоbacterium leprae. Сукцинатдегидрогеназа (a), ПО (б), цитохромоксидаза (в), НААН-диафораза (г) ×20000
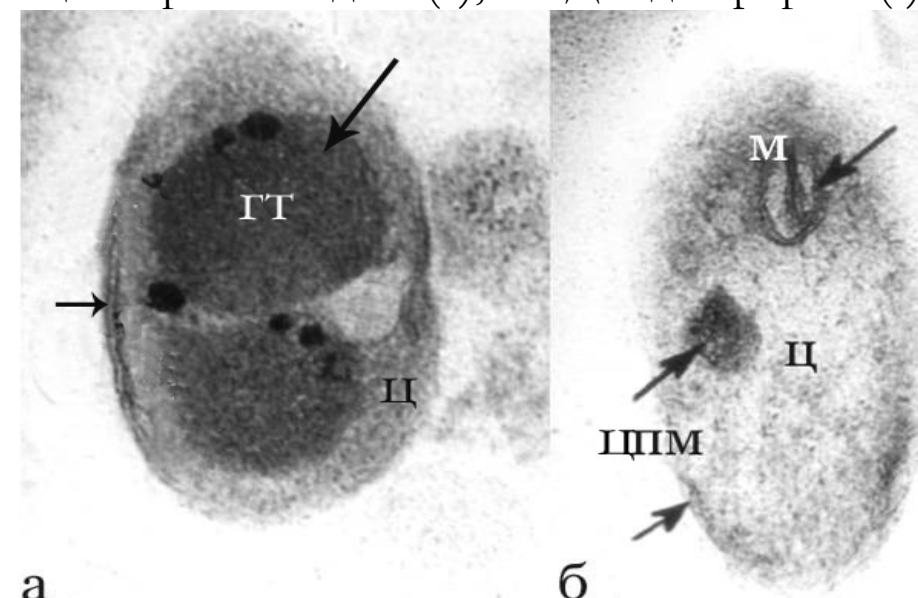

a

\section{б}

Рис. 16. Ферменты (стрелки) Мусоbacterium leprae. АТФ-аза (a), АОФА-оксидаза (б). $\times 20000$ 
В 1967 году у M.leprae впервые описана О-дифенолоксидаза (АОФАоксидаза) [153]. Фермент окисляет как D-АОФА-оксидазу, так и L-АОФА-оксидазу. Аифенолоксидаза может функционировать в качестве альтернативного респираторного механизма. Хинон, образовавшийся из АОФА, Аействует как носитель электронов, опосреАуя, таким образом, окисление Аругих раскисляющихся субстратов. ОчевиАно, что дифенолоксиАаза играет важную роль в выживании и росте микобактерий мепры [156]. Электронно-цитохимическими исследованиями, проведенными в НИИА, показано, что активность АОФАоксидазы М. leprae мокализуется в мембранных структурах и в цитоплазме микобактерий [81]. АОФА-оксидаза специфична только Аля M.leprae, что вкАючено в комплекс тестов Аля идентификации микобактерий Аепры (рис. 16 б).

В клетках M.leprae выявлено Ава типа магниево-зависимой АТФ-азы: мембранно-связанная и цитоплазматическая. Фрагментарное распределение АТФ-азы в структурах цитоплазматической мембраны, по-виАимому, явАяется показателем сниженной активности метаболических процессов у M.leprae, a наличие фермента в «гомогенных тельцах» (рис. 16 а) позволяет предположить, что в этих вкАючениях иАут процессы, связанные с гиАролизом АТФ [56].

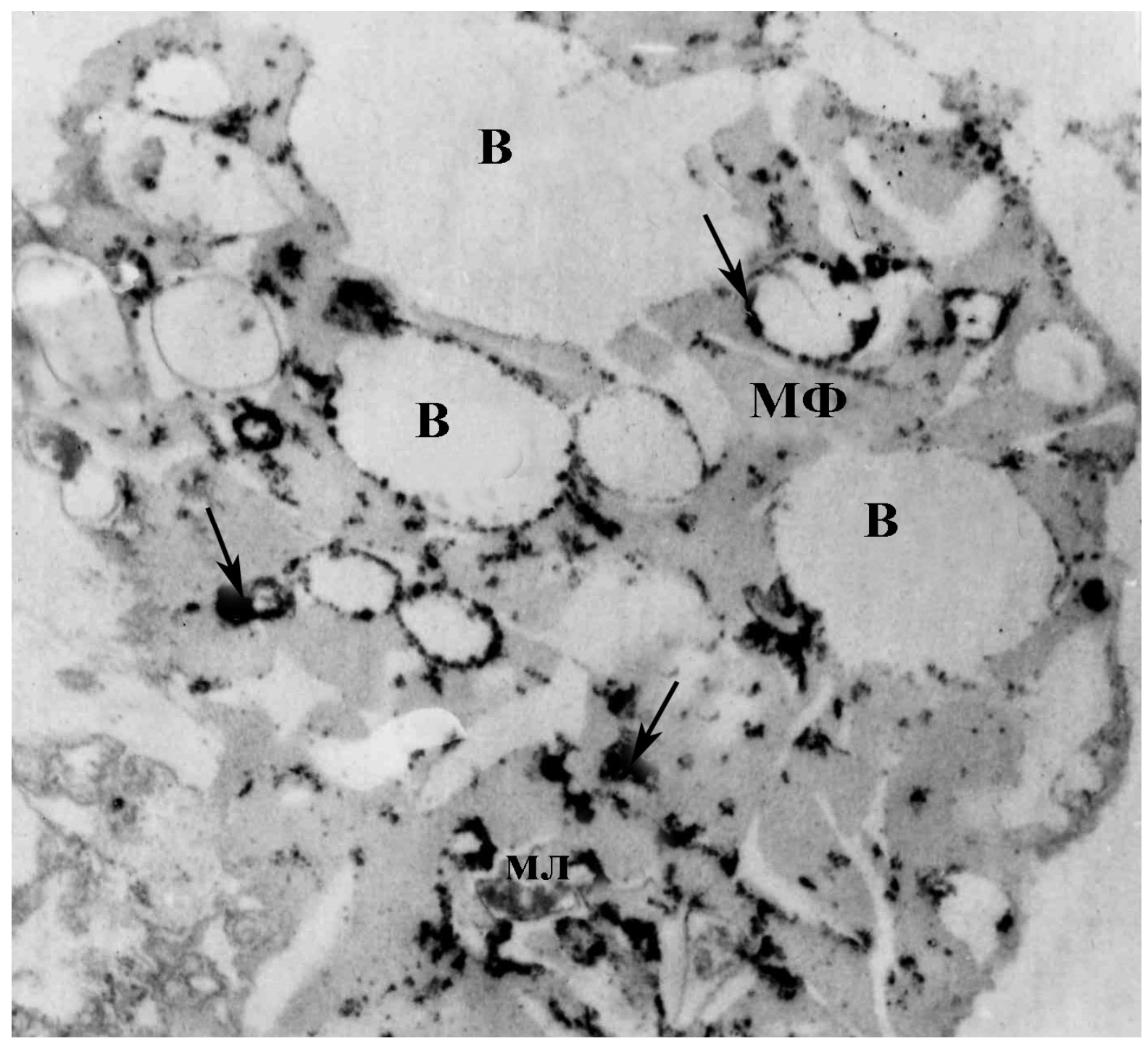

Рис. 17. Кислая фосфатаза (стрелки) в цитоплазме макрофага. $\times 15000$ 


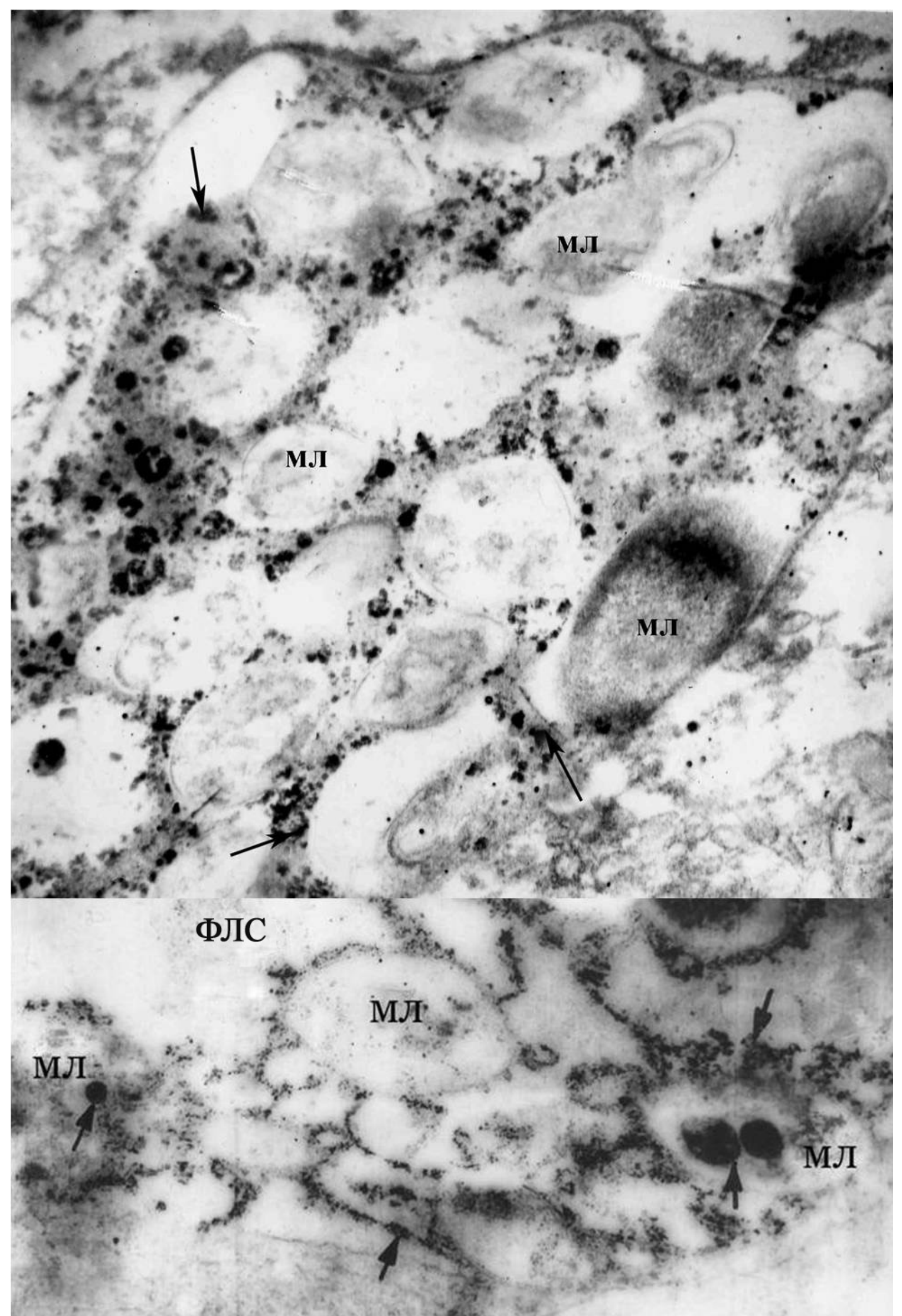

Рис. 18. $\beta$-глюкуронидаза в цитоплазме макрофага и Мусоbacterium leprae.× 15000 
Аля понимания механизмов патогенеза мепры большое значение имеют исследования показателей функциональной активности клеток системы мононуклеарных фагоцитов (СМФ), играющих важную роль в формировании неспецифической резистентности и явАяющихся факторами специфической защиты против M.leprae. Функциональные возможности клеток СМФ макрофагов во многом зависят как от состояния поверхностных рецепторов, так и от уровня и пространственной организации окислительно-восстановительных ферментов и гиАролитических ферментов Аизосом.

Изучалась ультраструктурная мокализация активности кислой фосфатазы (рис. 17) и $\beta$-глюкуронилазы (рис. 18) в цитоплазме мепрозных макрофагов больных мепрой мепроматозного типа. Маркеры активности кислой фосфатазы и $\beta$-глюкурониАазы выяв ялись в умеренно электронно-плотных вкАючениях, идентифицированных как мизосомы, а также непосредственно в цитоплазме кАеток. Выявилось несколько типов Аизосом, различающихся по количественному содержанию ферментов. Высокое содержание кизосомальных ферментов, располагающихся в фаголизосоме непосредственно вокруг M.leprae, связывалось с активным Аизисом микобактерий (рис. 19).

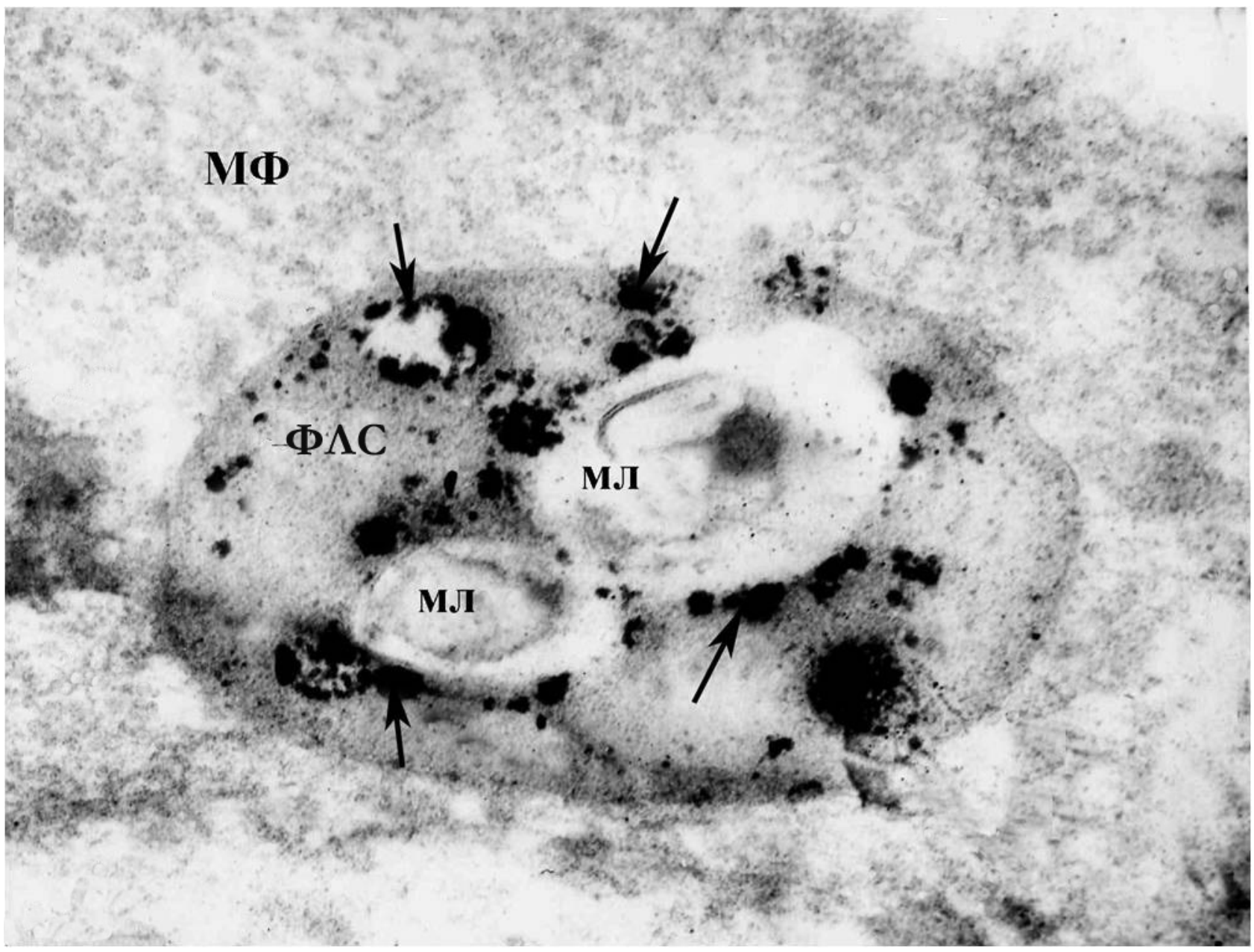

Рис. 19. Высокая активность лизосомальных ферментов в $Ф \Lambda$ С макрофага. $\times 20000$ 
В макрофагах обнаружены также Аизосомы и фаголизосомы, Аишенные основных гицролаз и содержащие интактные M.leprae (рис. 20а, 20б). Полученные результаты позволяют преАположить, что одним из факторов неАостаточной функциональной активности фагоцитов при мепре явцяется низкая активность основных гиАролитических ферментов лизосом, что может быть связано с нарушением целостности мембраны фаголизосомы.

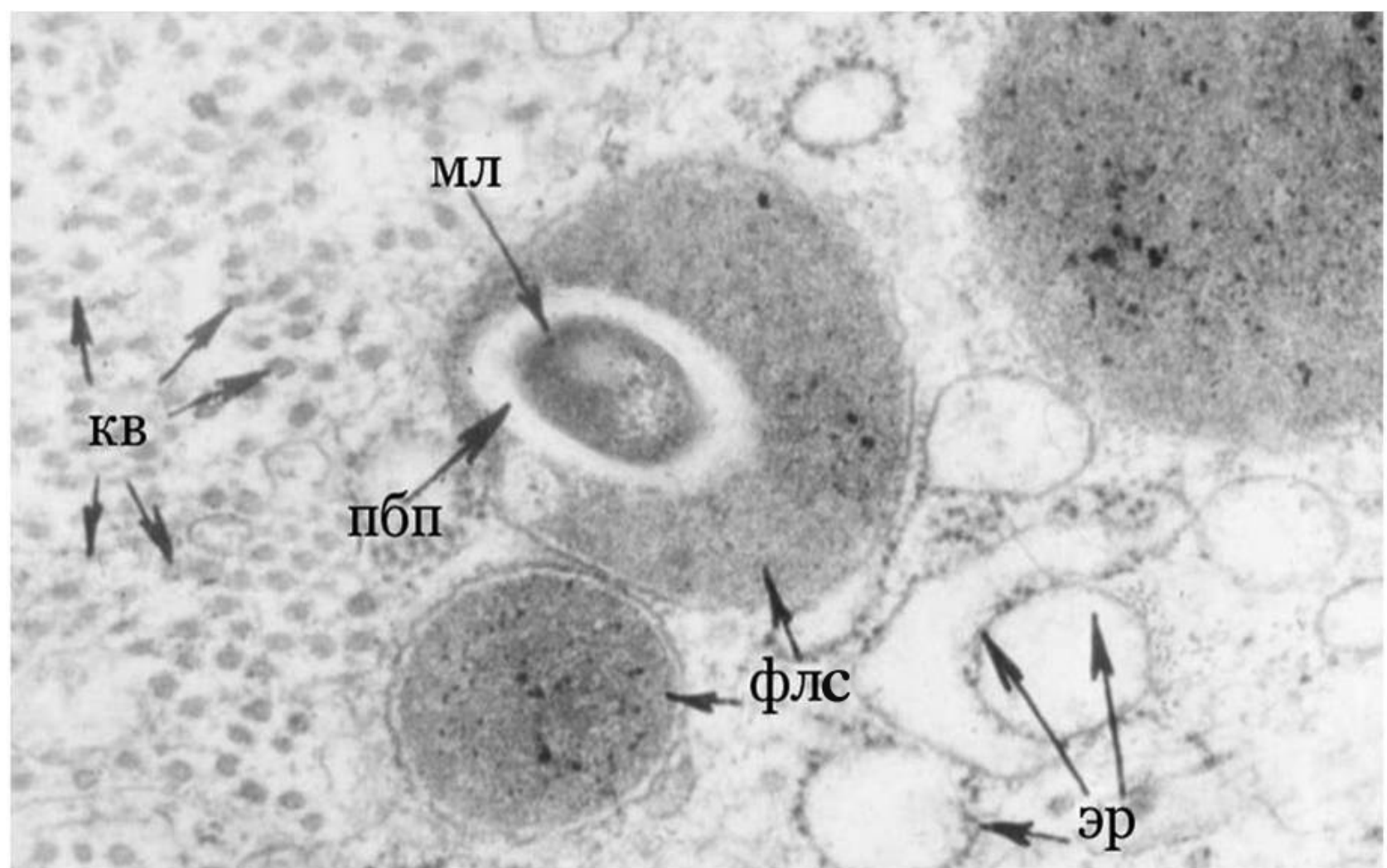

Рис. 20. Низкая активность Аизосомальных ферментов в $Ф \Lambda$ С макрофага. $\times 20000$ Активность $\beta$-глюкуронидазы на ультратонких срезах определялась в лизосомах и цитоплазме Аишь отАельных фагоцитов и преимущественно в структурах микобактерий мепры [48] (рис. 21).

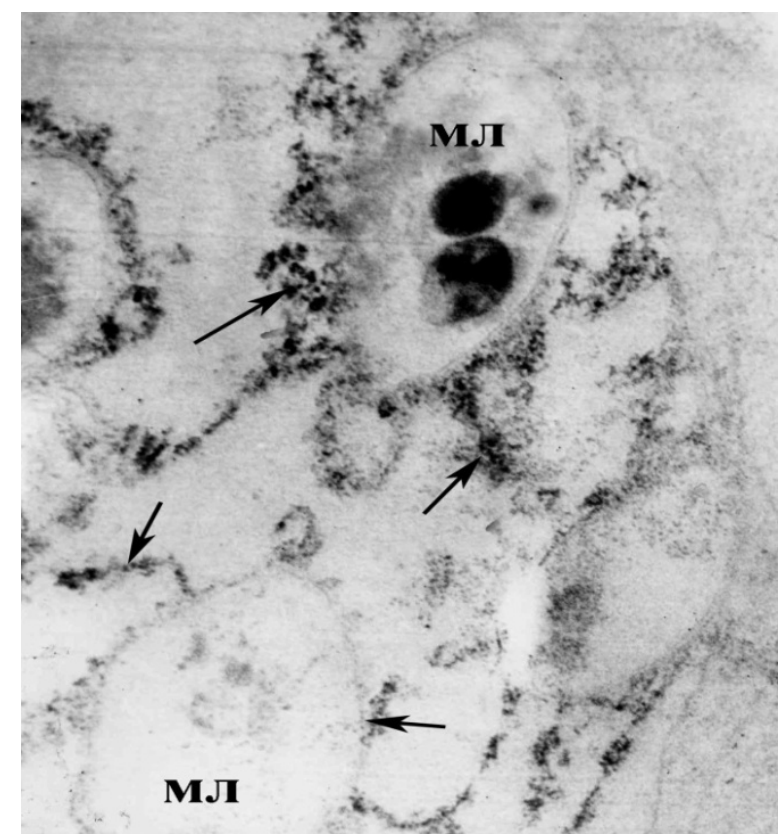

Рис. 21. Высокая активность $\beta$-глюкуронидазы в цитоплазме макрофага и в основном в Mycobacterium leprae. $\times 20000$ 
Наличие гиАролаз в цитоплазме макрофагов указывает на патологическую проницаемость мембран мизосом и, как следствие, невозможность активного воздействия на M.leprae. Факт нарушения структурной цемостности мембран лизосом и присутствие гилролаз в цитоплазме фагоцита, а в результате этого возможность аутолиза компонентов клетки - могут объяснить происхождение описанных ранее у больных мепрой мепроматозного типа аутоантигенов и аутоантител и причину симптомов аутоиммунного заболевания [48].

Известно, что миелопероксилаза (МП) фагоцитов играет ключевую роль в процессах фагоцитоза патогенных микроорганизмов. Установлено, что различия в степени активности МП, содержащейся в макрофагах, составляющих основу гранулем у больных мепрой цепроматозного типа, существенно вАияют на завершенность фагоцитоза M.leprae. Макрофаги с низкой активностью МП, проявАяя низкую фагоцитарную способность, содержали в цитоплазме большое количество жизнеспособных M.leprae. И, напротив, макрофаги с высокой активностью МП проявАяли способность к активному мизису возбудителя [49] (рис. 22 а, 22 б).
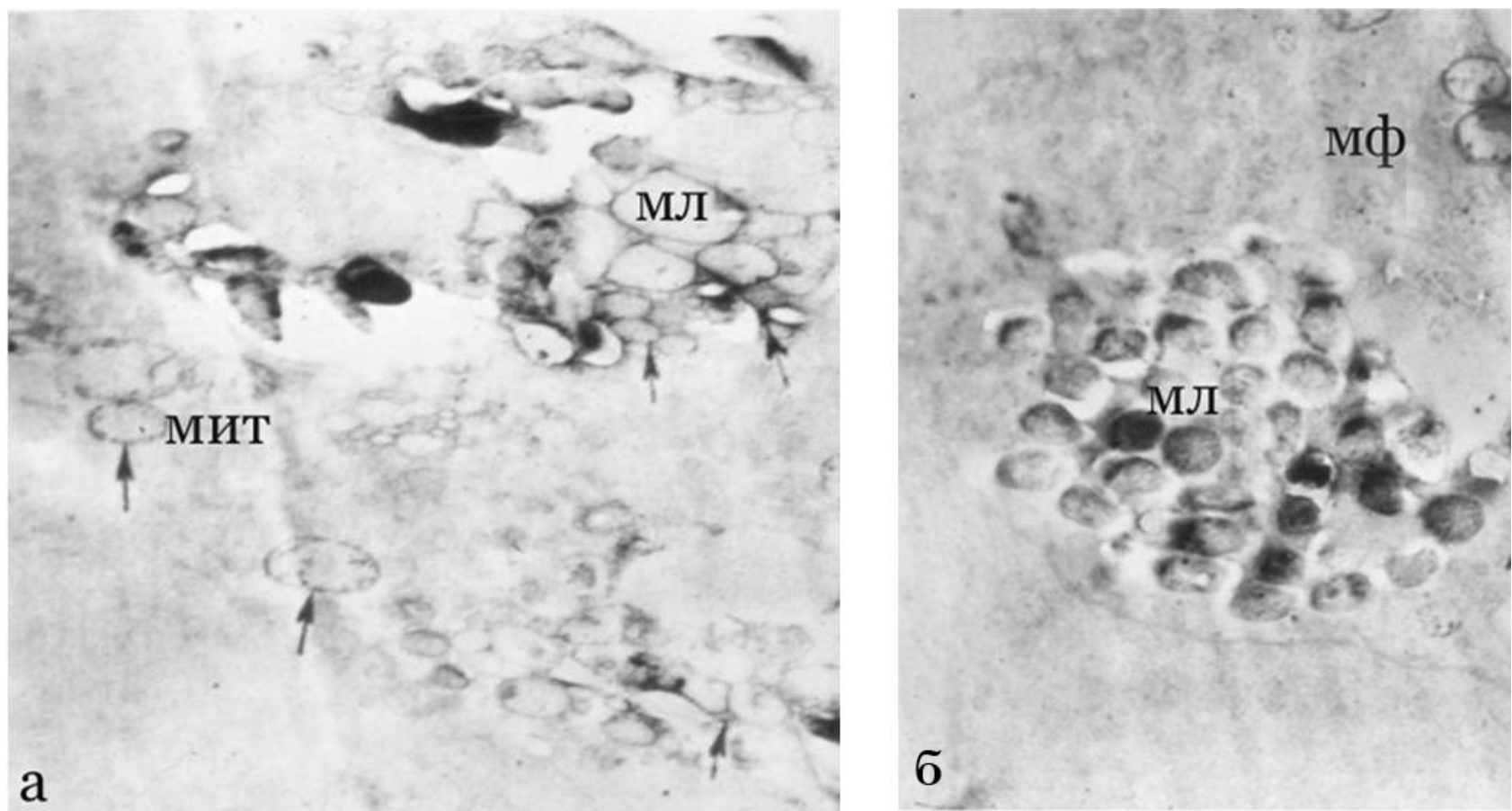

Рис. 22. Высокая активность миелопероксидазы в цитоплазме МФ (a), низкая активность миелопероксидазы в цитоплазме МФ (б) × 20000

Многолетние наблюдения эффективности противолепрозной терапии (учитывались скорость и стойкость регресса заболевания) в сопоставлении с электронно-микроскопическим контролем уровня активности МП макрофагов гранулем при поступлении больных в стационар показали, что высокий уровень активности МП макрофагов коррелировац с активным завершенным фагоцитозом M.leprae, быстрой элиминацией возбудителя из организма и наибольшей эффективностью терапии (стойкостью регресса). Низкая активность МП фагоцитов гранулем служила показателем низких барьерных функций организма (частые обострения на фоне терапии). Эти больные были отнесены в группу 
повышенного риска возникновения обострения мепрозного процесса. Продемонстрирована возможность прогнозирования течения $е$ епры и эффективности терапии [50] (рис. 22 а, 22 б).

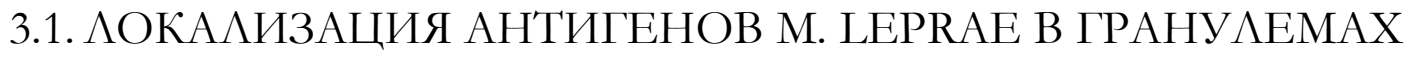 БО $А$ БЫЫХ}

Широкий спектр проявцений мепры от полярного Аепроматозного типа Ао полярного туберкулоидного и видимое несоответствие межАу количеством жизнеспособных M.leprae в тканях и степенью тканевых реакций [141] обусловливают актуальность Аетального изучения иммунологических механизмов и их роли в патогенезе этого заболевания. Так, существует предположение о том, что оАной из причин поврежАения тканей при мепре явАяются иммунные комплексы, в состав которых входят микобактериальные антигены и специфические иммуноглобулины сыворотки [83]. Аепрозная узловатая эритема явцяется непрямым доказательством образования в организме комплексов антигенантитело [176].

Известны данные по обнаружению антигенов M.leprae в тканях больных с помощью специфических антител, меченных пероксилазой или колцоилным золотом, также и на ультраструктурном уровне [91, 128, 142]. ОАнако в этих

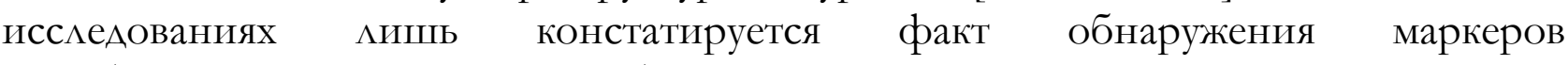
микобактериальных антигенов, без указания мест нахождения их в структурах бактериальных клеток и учета связи с морфологическими изменениями ткани.

Нами были изучены биоптаты мепром 10 впервые зарегистрированных

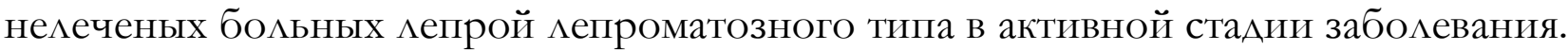

А^я получения антител кроликов иммунизировали обработанными ультразвуком препаратами M.leprae и M.avium. Использовали M.leprae, пассированные интраплантарно на мышах и вылеленные из инфицированных тканей по методу P.Draper [102]. М. avium выращивали на среде Сотона. Схема иммунизации включала четырехкратные с интервалом в 1 неделю внутрикожные инъекции с аАъювантом Фрейнда. Забор крови проводили на 9-10 день после 1-2 реиммунизаций. Титр гипериммунных кроличьих сывороток в реакции Авойной диффузии в геле был Аля антител к M.leprae (AT-M. leprae) и антител к М. avium (AT-avium) 1:128 и 1:512 соответственно. Путем Авукратного высаливания насыщенным и полунасыщенным раствором сернокислого аммония из иммунных сывороток вылемяли иммуноглобулины, которые конъюгировали с пероксилазой (фирмы «Serva») путем перийодатного окисления [179]. Активность пероксидантных конъюгатов (ПК) проверяли в прямом твердофазном иммуноферментном анализе. Рабочие титры ПК соответствова^и 1:500. ПК стабимизировали 10\% раствором BSA и хранили при температуре $20^{\circ}$ С до использования.

Выявление антигена проводили одноэтапным методом [143]. Пероксидазу выяв яяли по методу R.C. Graham, M.J. Karnovsky (1966). Эндогенную пероксидазу предварительно блокировали, обрабатывая материал 0,22\% перийодистой 
кислотой в течение 45 секунА. После заключения в эпоксидные смолы ультратонкие срезы просматривали в электронных микроскопах.

На ультратонких срезах тканей мепром отмечались группы мепрозных макрофагов, содержащие большое количество M.leprae. Маркеры антигенов микобактерий (AT-M.leprae и AT-M.avium) мокализовались в электронно-плотном слое клеточной стенки, а также снаружи ее электронно-прозрачного слоя в области микрокапсулы. Они выявцялись в виле мелких электронно-плотных гранул размерами 10-50 нм в диаметре. Встречались и скопления гранул, в основном, в области микрокапсулы M.leprae (рис. 23).

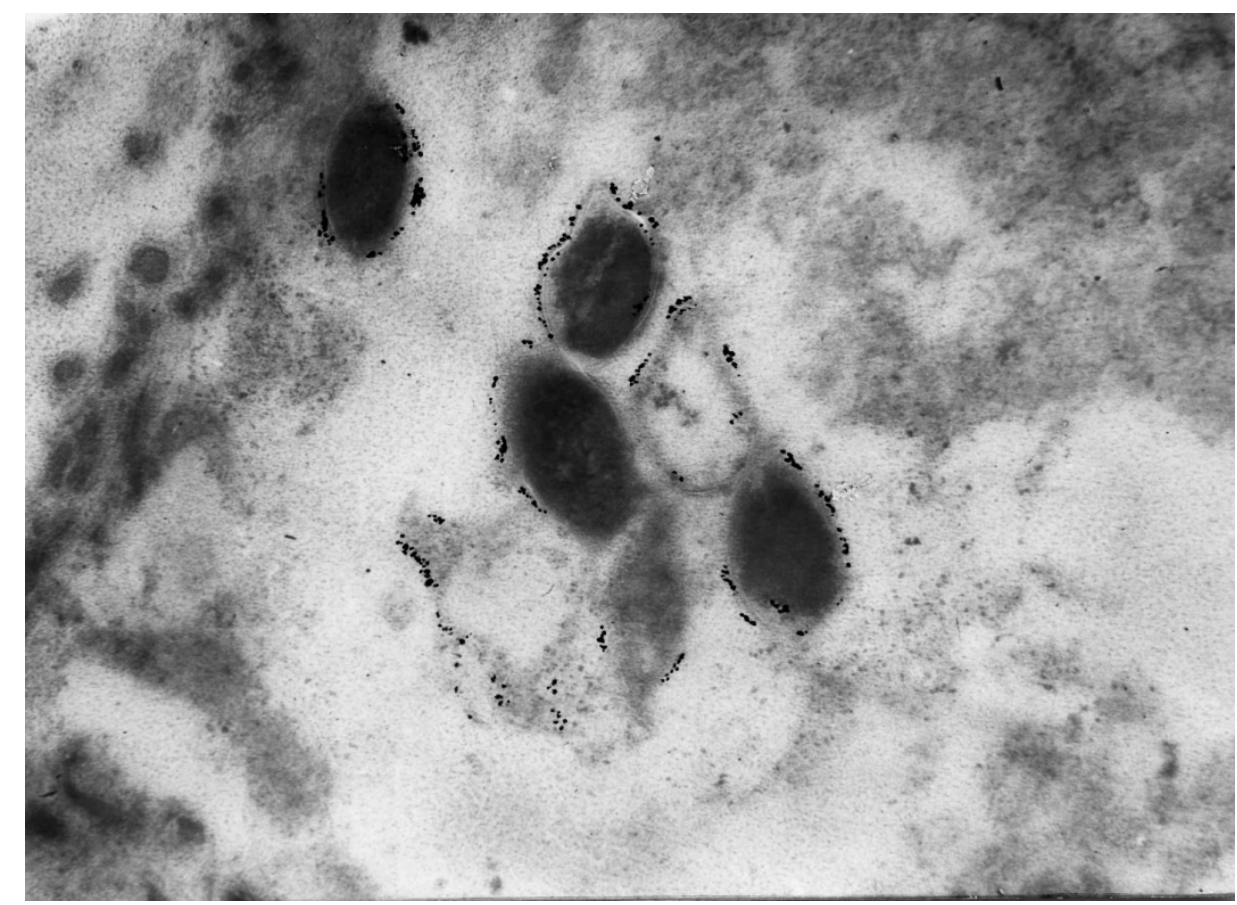

Рис. 23. Аокализация антигенов в структуре МК и КС Mycobacterium leprae. $\times 20000$

Судя по интенсивности окрашивания, количество выявленного антигена в M.leprae не зависело от степени дезинтеграции микобактериальных клеток: в структурах клеточной стенки и микрокапсулы интактных клеток и тех же структурах Аезинтегрированных бактерий с сохраненными клеточными стенками и полностью мизированной цитоплазмой содержалось относительно равное количество маркера. В контроле электронно-плотные отложения маркера в клеточной стенке и микрокапсуле микобактерий отсутствова^и.

В тканях, окружающих фагоциты, маркеры на антигены выяв ялись в кол^агеновых волокнах мепромы и перикапилцярной соединительной ткани. Особенно часто они Аокализовались вокруг капиццяров и Аругих сосудов мелкого и среднего калибра в области колцагеновых волокон соединительнотканного каркаса сосудов. Нередко маркеры антигенов выяв ялись в коллагеновых волокнах Аермы. В обоих случаях в местах их отложений наблюдалась разреженность волокон и исчезновение поперечной исчерченности, что характеризует нарушение структурной целостности кол^агена (рис. 24 а, б). 


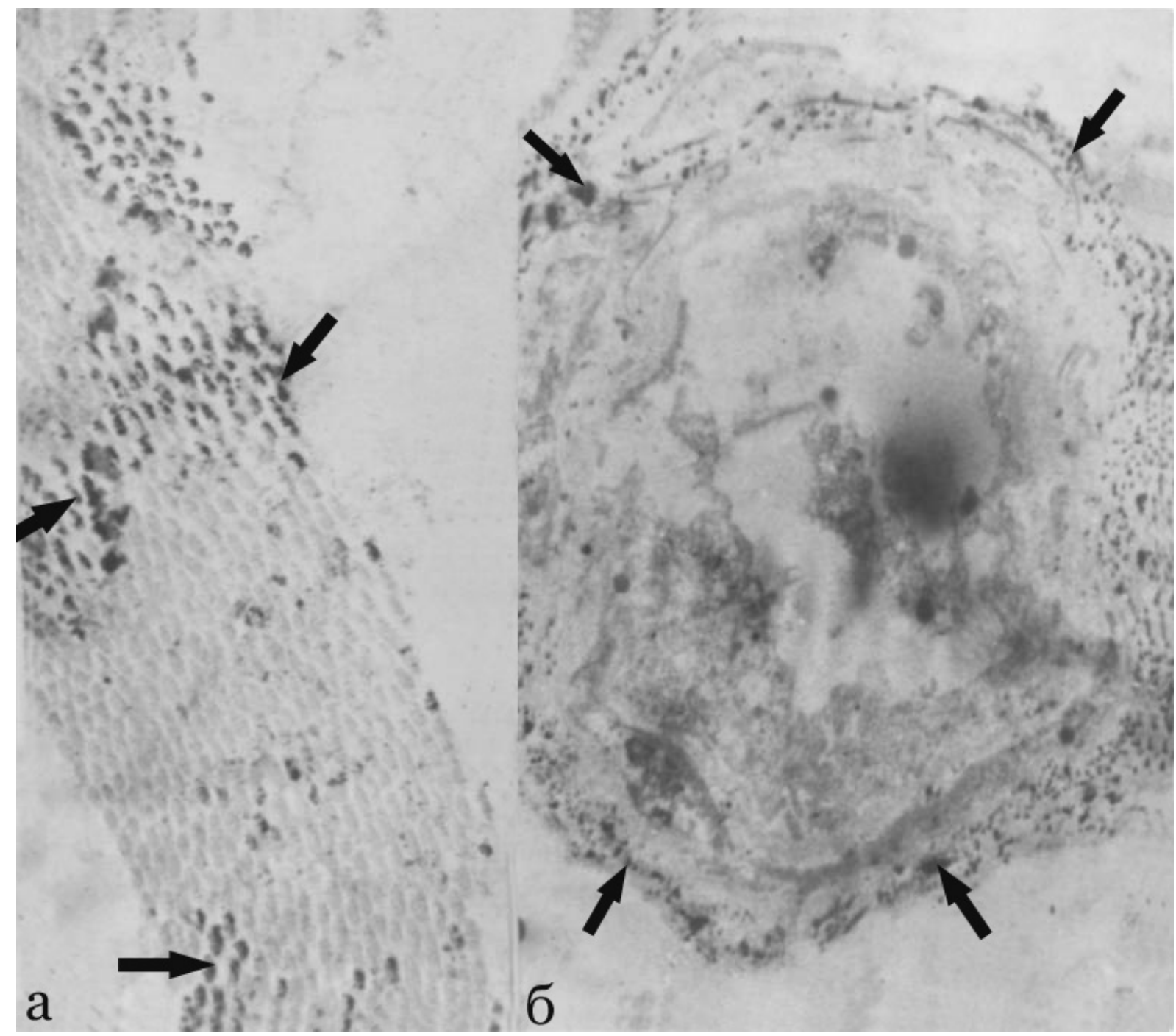

Рис. 24. Поражение антигенами M.leprae кольагеновых волокон дермы (a) и капимляров (б) в гранулеме больного мепрой. ×10000

В контроле пероксидаза в области колмагеновых волокон и оболочки микобактерий не выявАялась.

Учитывая факт нарушения ультраструктуры колмагеновых волокон дермы и перикапилмярной соединительной ткани в местах мокализации маркеров микобактериальных антигенов, можно предположить, что в Аанном случае выявились не только свободные антигены М. leprae, но и в большей мере фиксированные в тканях иммунные комплексы антиген-антитело, как известно, обладающие поврежАающим действием на структуру ткани [6].

Известно, что поражение кровеносных сосудов и колмагеновых волокон явАяется одним из главных факторов тканевой патологии при мепре [42].

Если в отношении Аругих микобактерий, растущих на искусственных питательных средах, в частности, микобактерий туберкулеза значение микрокапсулы как носителя специфического антигена относительно ясно [32], то роль микрокапсулы M.leprae была изучена недостаточно. Как показало исследование, мокализация в структуре микрокапсулы M. leprae микобактериального антигена определяет ее значение в аАаптационных взаимоотношениях клеток макро- и микроорганизма при мепре. Эти Аанные 
позволяют характеризовать микрокапсулу M.leprae как полифункциональный органоиА, осуществляющий не только функции связывания клеток межАу собой и возможность фиксации к поверхности, а также защиты от воздействий внешней среды, но и определяющий вирулентные и иммуногенные свойства возбудителя. Важным патогенетическим фактором следует считать наличие фиксированных иммунных комплексов в местах наибольшего повреждения ткани (соединительнотканный каркас сосудов и коллагеновые волокна мепромы).

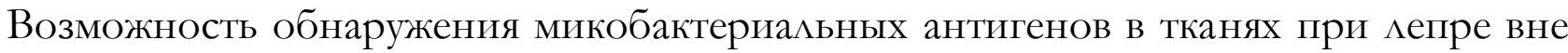
связи с мокализацией возбудителя предполагает перспективность использования иммуноцитохимических методов в Аиагностике малобактериальных форм мепры (недифференцированной, туберкулоилной) [55].

\section{2. ФЕРМЕНТНЫЙ СОСТАВ MYСОВАСТЕRIUM LEPRAE}

Определение ферментного состава M.leprae в значительной мере связано с методическими трудностями получения чистой суспензии микобактерий Аепры из инфицированных тканей и в некоторой степени с недостаточным количеством материала (выход очищенной суспензии невелик). Возможные изменения ферментного состава клеток M.leprae в процессе очистки накладывают свой отпечаток на результаты исследований. Тем не менее многие исследователи применяли протеолитические ферменты кибо хлороформ Аля экстракции M.leprae из тканей больных мепрой или экспериментально зараженных мепрой животных Аля изучения микроорганизмов биохимическими методами. Но при выделении M.leprae из тканей возможна адсорбция ферментов тканей на клетках M.leprae, и это подвергает сомнению точность полученных результатов.

В 1960 году B.M. Braganca, K. Prabhakaran [92], изучая суспензию М. leprae, очищенную от тканей по методу Dharmendra, обнаружили посреАством спектрофотометрического анализа наличие в клетках микобактерий мепры сукцинатдегидрогеназы, пируватоксидазы, цитохромоксидазы, цитохромредуктазы и мактатдегидрогеназы. В 1967 году К. Prabhakaran $[152,153]$ подтвердил наличие в клетках M.leprae цитохром-С-оксидазы и сукцинатдегидрогеназы. Активность обнаруженных ферментов, как отмечено в обеих работах, оказалась очень низкой. На слабую метаболическую активность M.leprae указывали также J.H. Hanks и C.T. Gray (1954). Авторы считали невозможным использование M.leprae экзогенных субстратов. L. Kato в 1973 году обнаружиц в клетках M. leprae высокую концентрацию рибулозо-дифосфат-карбоксилазы, являющейся катализатором углерода. Автор продемонстрировац низкую активность НААФ-оксидазы, отсутствие $\alpha$-кетоглютардегидрогеназы, что свидетельствует о нарушении цикла трикарбоновых кислот. Он предположиц, что $\mathrm{M} \Lambda$ - инертный «житель» клетки организма-хозяина, выживает и размножается, используя только неорганический материал, не заимствуя у клетки организма-хозяина существенных субстратов и не влияя на ферменты этой клетки. По сообщению Е. Matsuo, O.K. Skinsnes (1974), O.K. Skinsnes и Ар. (1975), M.leprae не способны использовать углеводные элементы, но хорошо утилизируют кислые мукополисахариды, в частности, гиалуроновую кислоту. 
K. Prabhakaran, W.F. Kirchheimer (1966), K. Prabhakaran (1967) сообщили об избирательном окислении диоксифенилоксидазы (АОФА-оксидазы) M.leprae, что позволяет Аифференцировать их от микобактерий мепры крыс. Этот фермент окислял как L-, так и D-АОФА-оксидазу и был активен в отношении аАреналина и нораАреналина. Предполагается, что АОФА-оксидаза M.leprae участвует в качестве переносчика эмектронов дыхательной цепи в клетках M.leprae, которые характеризуются низким уровнем активности цитохромной и флавопротеиАной систем. АОФА-оксидаза отсутствует у Аругих видов микобактерий, поэтому изучение АОФА-оксидазной активности вкАючено в комплекс тестов идентификации M.leprae [154]. А^я оценки специфичности и мест цокализации активности АОФА-оксидазы нами проведено электронно-цитохимическое исследование активности АОФА-оксидазы у разАичных видов микобактерий. Выявление АОФА-оксидазы проводили по методу Мисима [17]. В результате продемонстрирована мокализация активности D-АОФА-оксидазы в цитоплазме

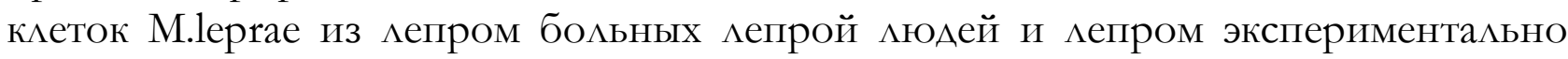
зараженных мепрой животных (мыши, броненосцы) в виде округлых электронноплотных образований продукта утилизации D-АОФА-оксидазы, преимущественно связанных с цитоплазматической мембраной. Срезы М. lерrae характеризовались усилением электронно-плотных слоев цитоплазматической мембраны и мезосом. Аналогичные признаки при изучении ультратонких срезов культивируемых микобактерий отсутствова^и. Активность L-АОФА-оксидазы и DL-АОФАоксидазы методами электронно-микроскопической цитохимии не определялась [51]. При использовании меченого АОФА было показано, что связывание Аиоксифенилаланина является специфическим Аля M.leprae ферментативным процессом [155]. L. Kato et. al. (1975) путем спектрофотометрии обнаружили в клетках M. leprae, полученных от броненосца, наличие цитохромов типа С, в, а $+\mathrm{a}_{3}$. У M.leprae выявлена активность $\beta$-глюкуронилазы [156], супероксидлисмутазы [134]. K. Prabhakaran в 1967 году обнаружил низкую активность каталазы и высокую активность пероксилазы в M.leprae. Супероксилдисмутаза осуществляет Аисмутацию анионов $\left(\mathrm{O}^{2-}\right)$ с образованием кислорода и перекиси водорода, а каталаза разлагает перекись водорода на кислород и воду. Пероксидаза участвует в Аыхательных процессах клетки. Активность пероксидазы и цитохромоксидазы, определенная методами электронной цитохимии, цокализовалась в мембранных структурах M.leprae, преимущественно в мезосомах [51]. 


\section{3. АИЗОСОМААЬНЫЕ ФЕРМЕНТЫ МАКРОФАГОВ ПРИ АЕПРЕ}

На ультратонких срезах мепрозных макрофагов гранулем активность кислой фосфатазы (КФ) выявлялась в образованиях округлой или овальной формы, умеренной электронно-оптической плотности размером от 0,4 Ао 1 мкм, илентифицированных как мизосомы, в фаголизосомах преимущественно вокруг фагоцитированных М. lepraе в виле отдельных гранул диаметром 8-100 нм, а также непосредственно в цитоплазме фагоцитов. В процессе фагоцитоза содержимое отАельных $и$ иосом, сливаясь, образует крупные скопления вокруг внутриклеточно расположенных М. leprae. Обнаружено несколько типов Аизосом, различающихся по содержанию маркера на КФ. При высоком содержании гранул маркера, располагающихся непосредственно вокруг M.leprae, наблюдалось выраженное переваривание возбудителя мепры, проявляющееся Аезинтеграцией цитоплазматической мембраны и внутрицитоплазматических структур бактериальных клеток с сохранением их клеточных стенок (рис. 19). Наряду с мизосомами, прояв яющими высокую активность КФ, в цитоплазме мепрозных макрофагов обнаруживались округлые образования умеренной электроннооптической плотности, маркеры на КФ в которых отсутствоваци. В этом случае заключенные в них M.leprae были интактны (рис. 20). Известно, что в процессе препарирования материала Аля электронно-микроскопических исслеАований в

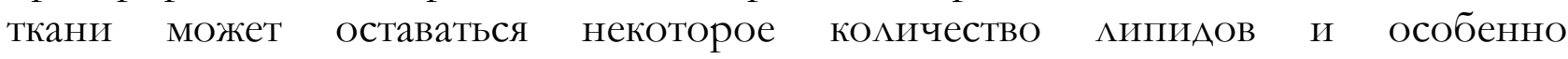
фосфолипилов, контрастирующихся четырехокисью осмия. Аля Аифференцирования Аипидов от Аизосом нами была проведена экстракция Аипилов из биологического материала. При этом обнаружено, что образования умеренной электронно-оптической плотности сохраняются в материале. Это позволило сделать вывоА, что образования умеренной электронно-оптической плотности, Аишенные маркеров на КФ, не яв яются Аипилами.

Активность $\beta$-глюкуронидазы на ультратонких срезах определялась электронно-плотными отложениями маркера в образованиях умеренной

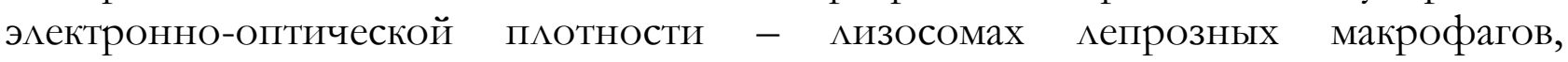
преимущественно вокруг фагоцитированных M.leprae, а также непосредственно в цитоплазме макрофага. Следует отметить, что активность $\beta$-глюкуронидазы определялась в лизосомах и цитоплазме лишь отлельных фагоцитов и преимущественно в структурах M.leprae (рис. 17, 18). В контроле отложения маркеров на кислую фосфатазу и $\beta$-глюкуронилазу отсутствовали [49].

Таким образом, одним из факторов, обусловливающих нарушение переваривающей функции макрофагов при мепре, является низкая активность КФ и $\beta$-глюкуронилазы мизосом фагоцитов. Наличие гилролаз непосредственно в цитоплазме фагоцитов указывает на нарушение структурной целостности мембран Аизосом и как следствие этого процесса - невозможность активного воздействия

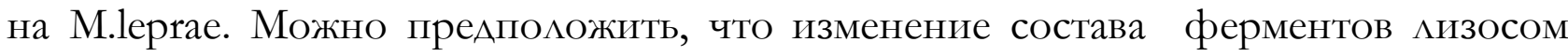
или деструкция их мембран происходит в период эндоцитобиоза M.leprae, поскольку мембраны мизосом чувствительны к аутоокислительным процессам, возникающим при взаимодействии фагоцита с возбудителем [88]. В этом случае 
терапевтическое действие сульфоновых препаратов при мепре может быть обусловлено их стабилизирующим влиянием на мембраны мизосом [49]. Факт нарушения структурной целостности мембран мизосом [140] и присутствие гилролаз в цитоплазме фагоцитов, а вследствие этого процесса возможность аутолиза компонентов клеток могут объяснить происхожАение описанных ранее [176] у больных мепрой мепроматозного типа аутоантигенов и антител и причину

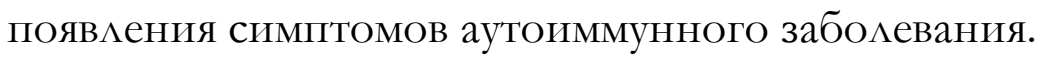

\section{4. ЗНАЧЕНИЕ МИЕАОПЕРОКСИААЗЫ ФАГОЦИТОВ}

Известно, что миелопероксидаза (МП) фагоцитов играет ключевую роль в процессах фагоцитоза патогенных микроорганизмов. Установлено, что различия в степени активности МП, содержащейся в макрофагах, существенно влияют на завершенность фагоцитоза M.leprae. Макрофаги с низкой активностью МП, прояв яяя низкую фагоцитарную способность, содержали в цитоплазме большое количество жизнеспособных M.leprae. И, напротив, макрофаги с высокой активностью МП прояв яяли способность к активному мизису возбудителя (рис. 22 а, б) [49]. Многолетние наблюдения эффективности противолепрозной терапии (учитывались скорость и стойкость регресса заболевания) в сопоставлении с уровнем активности МП макрофагов гранулем при поступлении больных в стационар показали, что высокий уровень активности МП макрофагов коррелировац с активным завершенным фагоцитозом M.leprae, быстрой элиминацией возбудителя из организма и наибольшей эффективностью терапии. Низкая активность МП фагоцитов гранулем служила показателем низких барьерных функций организма (частые обострения заболевания на фоне терапии). Эти больные были отнесены в группу повышенного риска возникновения обострения инфекционного процесса. Продемонстрирована возможность прогнозирования течения мепры и эффективности терапии [50].

Учитывая тот факт, что МП-система играет огромную роль в кимлинге патогенных микроорганизмов, в том числе, как доказано нами, и M.leprae, мы исследовали препараты пероксидазы (Аиофилизированная пероксилаза из корня хрена) на мышах, экспериментально зараженных M.leprae (модель Шепарда) [165]. При этом оказалось, что пероксидаза, наравне со специфическим противолепрозным средством - диаминодифенилсульфоном ( $\Lambda$ С) значительно подав яет размножение M.leprae (рис. 25 а, б, в) [46, 47].

Проведенные исследования дополняют существующие сведения о биологии M.leprae, раскрывают неясные вопросы патогенеза цепры и служат основанием Аля углубленного исследования с целью поиска возможностей клинического применения ферментотерапии пероксидазой. 


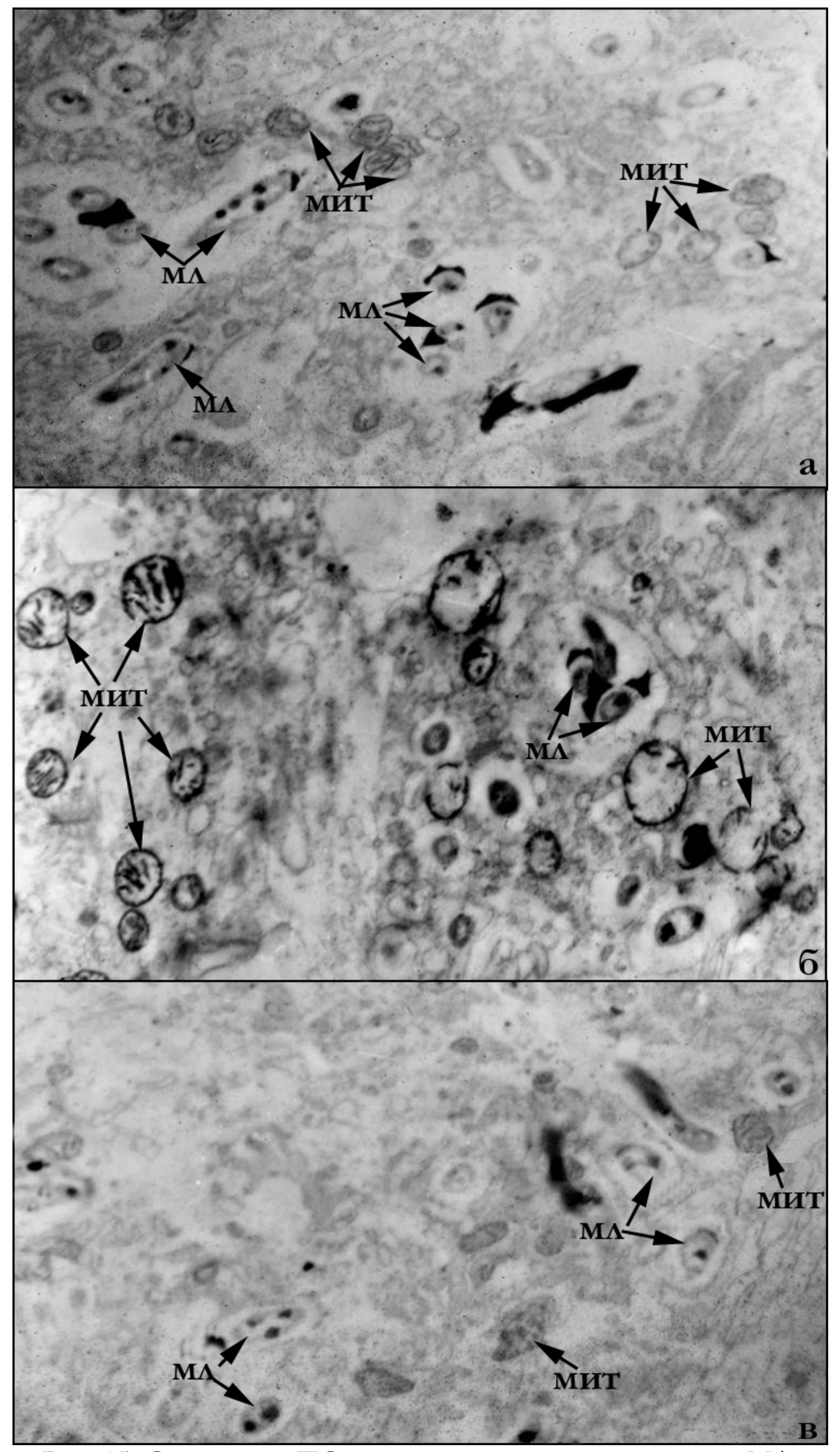

Рис. 25. Отложение ПО в электронно-прозрачной зоне М $\Lambda$. a - при использовании препаратов пероксилазы; б - при кечении $\Lambda$ С; в - контроль. $\times 20000$ 


\section{5. СОВЕРШЕНСТВОВАНИЕ МОАЕАИ ШЕПАРАА}

В экспериментальных исследованиях на животных было показано, что искусственное Аостоверное снижение активности МП перитонеацьных макрофагов мышей за счет подобранной концентрации перекиси водорода способствовало Алительной персистенции в их цитоплазме поглощенных патогенных микобактерий (туберкулеза и мепры). Исследование, раскрывая механизмы развития хронических инфекционных заболеваний, важно Аля изучения механизмов иммунитета и Аля нового подхода к терапии этих заболеваний [45].

Создание оптимальной модели мепры, а также выявление факторов, способствующих размножению M.leprae в организме больного, явцяются наиболее актуальными вопросами современной мепрологии. Нами была постав ена цель - усовершенствовать экспериментальную модель мепры Шепарда на мышах (при которой обеспечивалось цокальное интраплантарное размножение M.leprae) путем избирательного воздействия на активность основной бактерициАной миелопероксидазной системы фагоцитов. А^я истощения

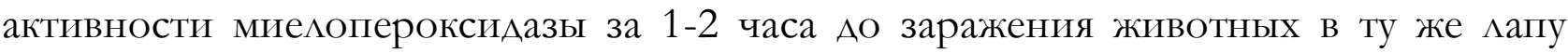
вводилось 0,03-0,05 мА 0,6\% раствора перекиси водорода (подобранная ранее эффективная концентрация, снижающая активность МП фагоцитов). К 5 мес. после заражения соотношение количества M.leprae в контрольных групп было максимальным (27,5:1 соответственно), к 7 мес. - 10:1, к 9 мес. - 9:1 и к 11 мес. - 6:1. Таким образом, количество М.leprae при истощении активности МП превалирова^о по сравнению с обычным способом заражения, и

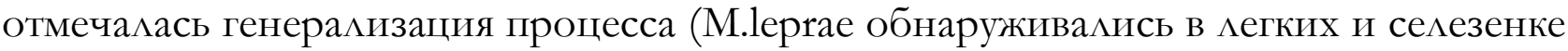
мышей). При электронно-микроскопическом исследовании на ультратонких срезах подушечек мап мышей в опытной и контрольной серии обнаруживались илентичные M.leprae. Обнаружена фрагментарная микрокапсула, полностью сохранившиеся слои клеточной стенки, трехслойная цитоплазматическая мембрана и ее производные - мезосомы, цитоплазма, в которой опредемялись рибосомы, нуклеоиА и включения (рис. 26а). На ультратонких срезах ткани мегкого и селезенки мышей в периол наибольшего развития процесса отмечались типичные M.leprae. Микобактерии имели хорошо заметную микрокапсулу, типичную клеточную стенку и плазматическую мембрану (рис. 26б). Из особенностей микобактерий, размножающихся во внутренних органах, следует отметить большое количество вкАючений с низкой электронно-оптической плотностью («гомогенные тельца») и большое количество включений волютина. В этих бактериальных клетках методом электронной цитохимии выявлена активность АОФА-оксидазы, что подтвержАает принаАлежность размножающихся во внутренних органах микобактерий к M.leprae (рис. 26в). Предложенная модификация модели мепры, связанная с истощением активности МП фагоцитарных клеток, приближает ее к иммунодефицитным состояниям у Аюдей, которые отмечены при Алительно текущих инфекционных и гранулематозных заболеваниях и, тем самым, к мепре [53]. 


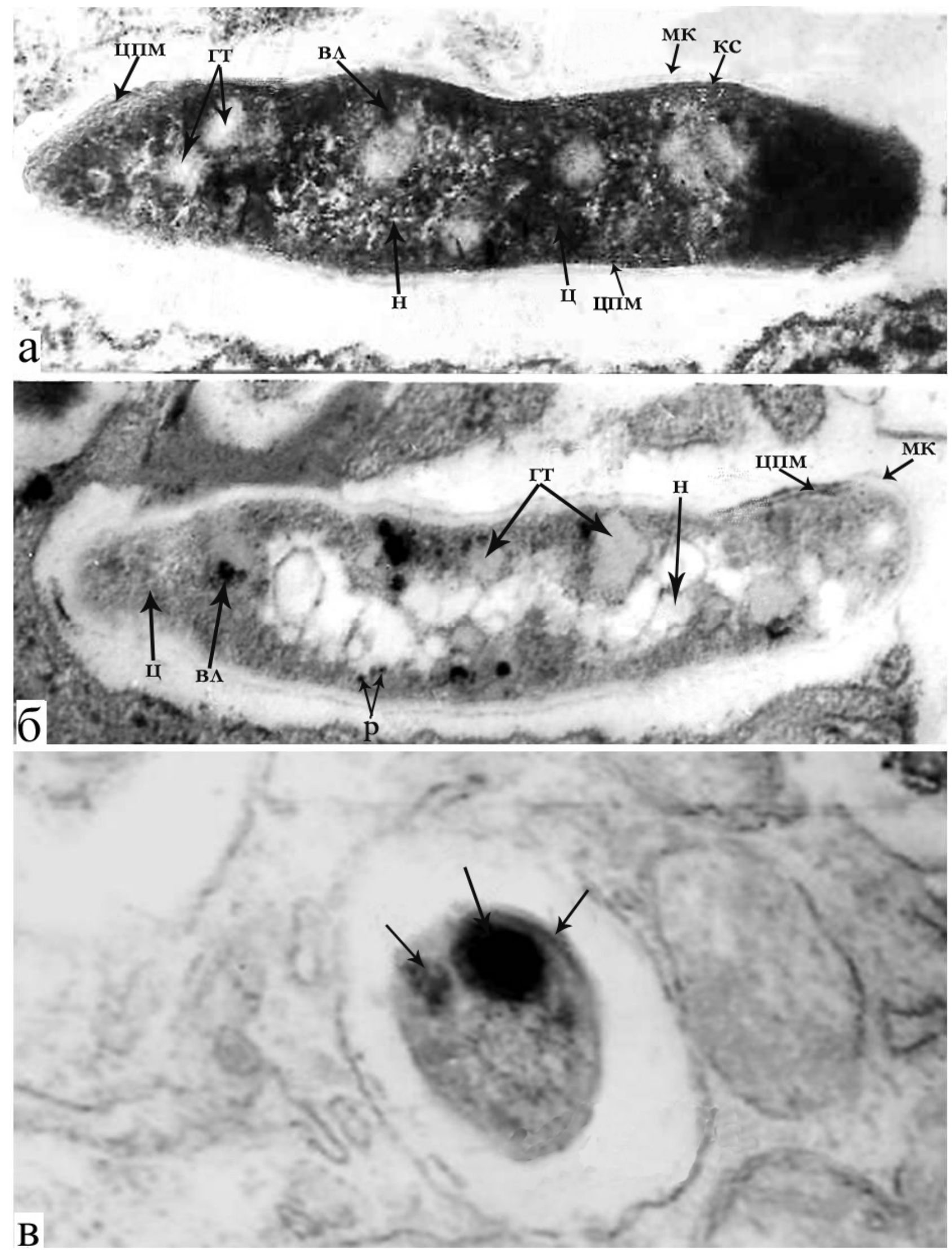

Рис. 26. M.leprae из подушечек мап мышей, зараженных интраплантарно (a). M.leprae на ультратонких срезах ткани селезенки (б). Активность АОФА-оксидазы в M.leprae, вылеленных из ткани мегкого и селезенки экспериментальных мышей (в). $\times 20000$ 


\section{4. ОЦЕНКА ФУНКЦИОНААЬНОГО СОСТОЯНИЯ АЕПРОЗНЫХ МАКРОФАГОВ}

Изучение функционального состояния мепрозных макрофагов, в цитоплазме которых выживает и размножается возбудитель мепры, позволяет уяснить причины эндоцитобиоза этих микроорганизмов, открывает возможность разработки в перспективе новых средств иммунотерапии.

УАьтраструктурные исследования лепрозных макрофрагов и их взаимоотношения с возбудителем мепры интенсивно проводились на рубеже 6070-х годов XX века. В это время опубликованы крупные обзорные работы [80, 85, 144], наиболее полно освещающие различные стороны ультраструктурной патологии при мепре. Развивавшиеся в последующие годы методы ультраструктурной цитохимии применялись к изучению мепрозных макрофагов Аишь в единичных случаях. Сведения о некоторых окислительновосстановительных и гилролитических ферментах, нуклеиновых кислотах и

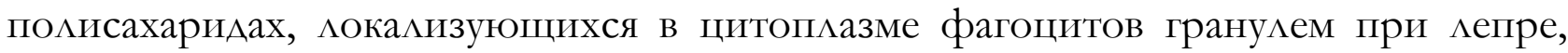
ограничивались только констатацией факта их наличия и степени активности [13, 26, 38]. Вопросы изучения внутриклеточной цокализации и распределения ферментов особенно важны и необходимы Аля выяснения роли энзимов в процессах дезинтеграции и полного мизиса возбудителя. Содержание основных метаболических веществ и активность ферментов в тканях позволяет судить о вариабельности уровня активности энзимов в зависимости от типа мепрозного процесса и стадии течения заболевания в связи с развитием регрессивных изменений и стойкости резидуальных проявлений Аля реабилитации больных [27].

Учитывая существенную роль кислородзависимой бактерициАной системы в обезвреживании патогенных бактерий [66, 164] и активность кАючевых окислительно-восстановительных ферментов в оценке функционального состояния фагоцитов, мы поставили целью исследовать ультраструктурную мокализацию миелопероксидазы (МП), сукцинатдегилрогеназы (САГ), цитохромоксилазы (ЦО) и НААН-Аиафоразы в мепрозных макрофагах гранулем

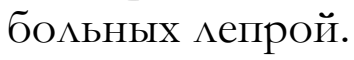

Изучали ультратонкие срезы мепрозных макрофагов в биоптатах пораженной кожи больных мепрой до начала мечения (8 человек) и больных с рециливом заболевания на фоне терапии (11 человек). Аиагноз у всех больных подтвержАался результатами кАинического обследования и гистологически. Биоптаты иссекали поА местной анестезией. Кусочки ткани или полученные на замораживающем микротоме толстые срезы сразу помещали в альдегидные фиксаторы или непосредственно в инкубационные среды. Аля электронноцитохимического исследования МП, САГ, ЦО и НААН-Аиафоразы использоваАи общепринятые методы [17]. УАьтратонкие срезы без Аополнительного контрастирования исследовали в электронном микроскопе «Tesla BS-540». 
На ультратонких срезах активность МП определялась в виде электронноплотного мелкогранулярного продукта полимеризации диаминобензидина (ААБ), Аокализующегося в мембранных структурах (цитоплазматической мембране и мезосомах) клеток микобактерий мепры (рис. 27 а, б, в, г) и в мембранах митохондрий мепрозных макрофагов.
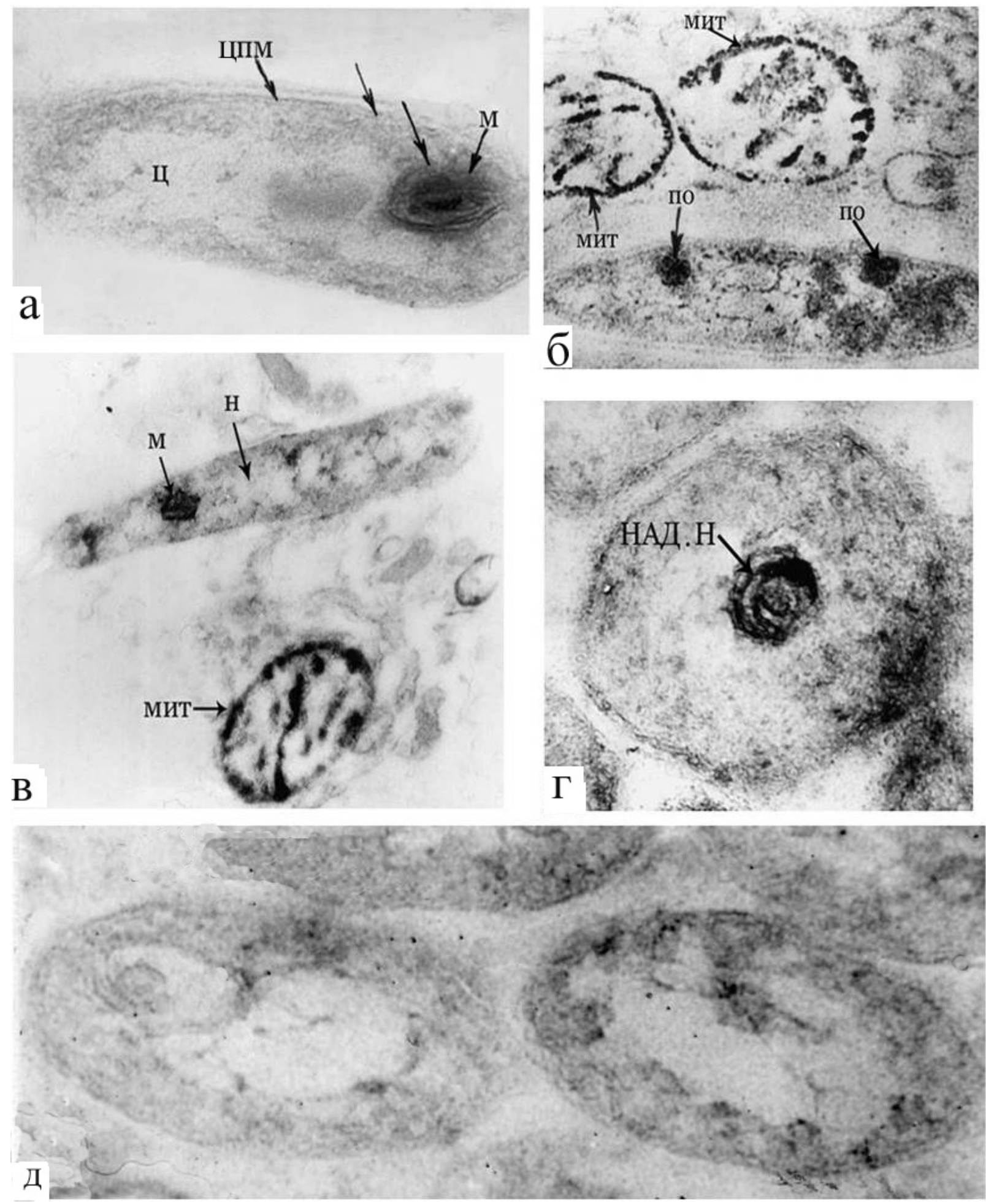

Рис. 27. Отложение $\triangle А Б$ (стрелки), маркирующие места активности сукцинатдегидрогеназа (а), ПО (б), цитохромоксидаза (в), НААН-диафораза (г) в мембранах Mусоbacterium leprae. Срезы клеток M.leprae, инкубированные в среде с цианидом и среде без ААБ $($ А $) \times 20000$ 
Отмечено Ава типа мепрозных макрофагов, разцичающихся по степени активности МП в цитоплазме. Макрофаги со слабой активностью МП характеризовались наличием Аишь единичных митохонАрий с отложениями ААБ, отсутствием активности МП на мембранах фагосом и электронно-прозрачной зоне, окружающей M.leprae. В цитоплазме таких фагоцитов встречались значительные скопления интактных M.leprae (рис. 22 б). В макрофрагах Аругого типа отмечалась высокая активность МП, что выражалось в увеличении числа митохонАрий с отложениями ААБ. В этом случае характерно наличие активности МП на мембранах фагосом и в электронно-прозрачной зоне (рис. 22 а, 28). Большое количество митохондрий с высокой активностью МП в сочетании с наличием осадка ААБ на мембране фагосомы и вокруг M.leprae коррелировало с активным Аизисом возбудителя, морфологически прояв яющемся в разрушении его цитоплазмы и сохранности Аишь ригилных клеточных стенок.

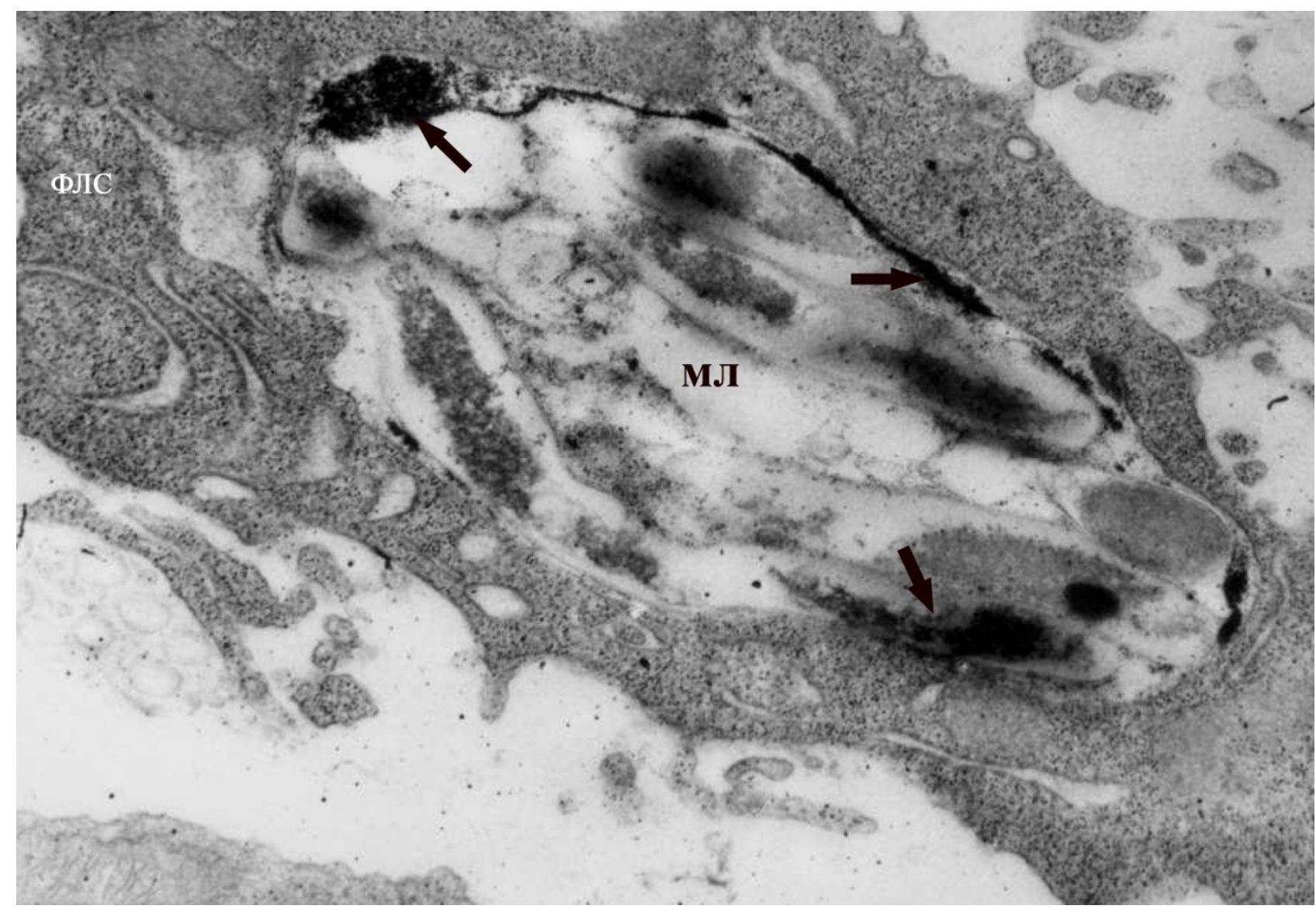

Рис. 28. Наличие активности пероксилазы на мембране фагосомы и в электроннопрозрачной зоне, вокруг M. leprae. × 20000

Активность САГ в фагоцитах гранулем нелеченых больных и больных с рециливом заболевания выявлялась преимущественно в мембранных структурах M.leprae и в мембранах мишь единичных митохондрий. Небольшие концентрации маркера на САГ определялись в электронно-прозрачной зоне, окружающей M.leprae. Вероятно, это фермент микробного происхожления. Сходные результаты 
получены и относительно мокализации активности НААН-диафоразы. Активность этого фермента выявлялась преимущественно в мембранных

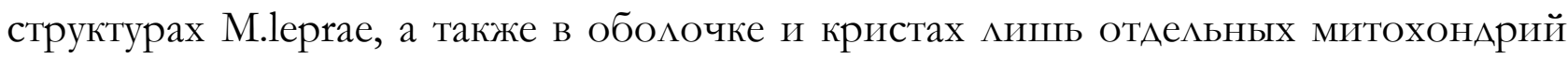
макрофагов (рис. 27в, г).

Известно, что бактерициАное Аействие МП фагоцитов обусловливается тем, что в присутствии перекиси водорода и галогенных соединений этот фермент приводит к повышению выработки токсичных продуктов [66]. Особенно важно присутствие МП внутри фагосом, содержащих патогенные микроорганизмы. В этом случае бактерицидное действие может усиливаться за счет не только фермента фагоцита, но и фермента самой бактериальной клетки. Если учитывать разницу в активности МП различных фагоцитов гранулемы больного, что может быть обусловлено и наследственными особенностями, то процентное соотношение фагоцитов активных и неактивных в отношении этого фермента может существенным образом влиять на характеристику гранулем и тип лепры.

У больных в активной стадии заболевания высокая активность ЦХО в мепрозных макрофагах, содержащих большое количество интактных M.leprae, явцяется показателем активной жизнедеятельности клеток, однако, вероятно, существенно не влияет на процессы дезинтеграции возбудителя мепры.

Наличие активности САГ в мембранных структурах M.leprae и низкая активность этого фермента в цитоплазме фагоцитов лепрозных гранулем позволяют предположить, что обнаруженная ранее гистохимическими методами

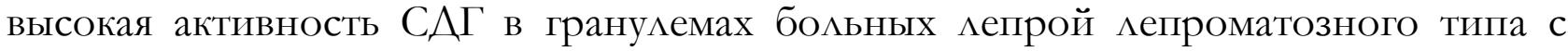
наличием большого количества M.leprae [26] обусловлена, в основном, ферментом, Аокализующемся в мембранных структурах возбудителя [49].

\section{5. ПОКОЯЩИЕСЯ ФОРМЫ M. LEPRAЕ}

Размножение возбудителя мепры (Mycobacterium leprae) в организме мабораторных животных и подлержание штаммов путем многократных пассажей на Аругом хозяине - важные этапы экспериментальной мепрологии ввиАу отсутствия надежных способов культивирования M.leprae in vitro. Известно, что возбудители инфекционных заболеваний при пассаже через организм различных видов животных быстро подвергаются фенотипической изменчивости $[8,11,41]$. Ранее показано, что пассаж на мышах и крысах M.leprae, вылеленных от больных мепрой, может приводить к изменению некоторых биологических свойств исходного штамма: обнаруживаются изменения в спектре высших жирных кислот и составе антигенов исходного штамма [22, 67]. ААаптация к новому хозяину в течение первых Авух пассажей сопровожАается повышением вирулентности возбудителя мепры, выражающееся в том, что начиная с третьего пассажа, сокращается инкубационный период экспериментальной мепры, нередки случаи генерализации инфекционного процесса [37, 62]. В комплексе биологических 
свойств M.leprae, размножающихся в организме мабораторных животных, важным яв яется характеристика ультраструктуры пассируемых штаммов.

Нами изучались M.leprae в биоптатах пораженной кожи больных мепрой (исходный штамм) и в инфицированных мапах мышей, зараженных интраплантарно по методу Шепарда (1-8 пассаж) [165]. Материал от животных был взят в следующие сроки с момента заражения: от мышей 1-2-го пассажей через 12-15 месяцев; 3-8-го пассажей - через 5 месяцев.

У ьтраструктура M.leprae, расположенных в макрофагах мепром больных мепрой (исходный штамм), в принципе сходна с таковой Аругих виАов микобактерий. Клетки палочковидной формы Алиной 3-8 мкм с Аиаметром поперечника 0,2-0,5 мкм. Оболочка M.leprae состоит из микрокапсулы, клеточной стенки и цитоплазматической мембраны. Мелкогранулярная цитоплазма заключает неярко выраженный нуклеоиА, рибосомы и различных размеров «гомогенные тельца» (гранулы с низкой электронно-оптической плотностью, природа которых до настоящего времени неизвестна) и зерна волюнина. Вокруг M. leprae, расположенных внутриклеточно, опрелеляется электронно-прозрачная зона («перибактериацьная зона»).

На ультратонких срезах подушечек мап мышей, зараженных суспензией M.leprae от больного человека (1-й пассаж), обнаруживались клетки системы мононуклеарных фагоцитов, солержащие M.leprae, ультраструктура которых отличалась от исходного штамма. Большая часть бактериальных клеток округлой или овацьной формы с диаметром поперечника 0,2-0,25 мкм. Электронно-плотная часть клеточной стенки утолщена (19-22 нм, против 3-10 нм у M.leprae исходного штамма). Эта часть клеточной стенки имела местами нечеткие контуры.

Электронно-прозрачная часть клеточной стенки не опрелелялась ввилу отсутствия микрокапсулы, в то время как у исходного штамма микрокапсула выявлялась обычными методами. У ряла клеток в цитоплазме определялись выраженные многослойные мембранные структуры - мезосомы. Характерным признаком M.leprae 1-го пассажа была выраженная электронно-оптическая плотность цитоплазмы. В цитоплазме отмечалось крайне малое количество рибосом, практически отсутствовали вкцючения и не обнаруживалось явно выраженного нукцеоида. Указанные признаки характерны Аля покоящихся форм бактериальных клеток. Вокруг микобактерий, расположенных в цитоплазме фагоцитов, так же как и у исходного штамма M.leprae, определялись «перибактериацьные зоны» (рис. 29 а).

У M.leprae 2-го пассажа (от мыши к мыши) наблюдалась фрагментарная (бахромчатая) микрокапсула и клеточная стенка общей толщиной 14-20 нм. К ней тесно прилегала трехслойная извитая цитоплазматическая мембрана толщиной 6-7,5 нм. Цитоплазма умеренной электронно-оптической плотности, мелкозернистая солержала немногочисленные рибосомы и полисомы, рассеянные Аиффузно, и включения типа «гомогенных телец». В центре клеток определялась ярко выраженная зона нуклеоида, содержащая нити и конгломераты АНК. В цитоплазме определялись многочисленные мембранные структуры (мезосомы) пластинчатого и гроздевиАного характера. 


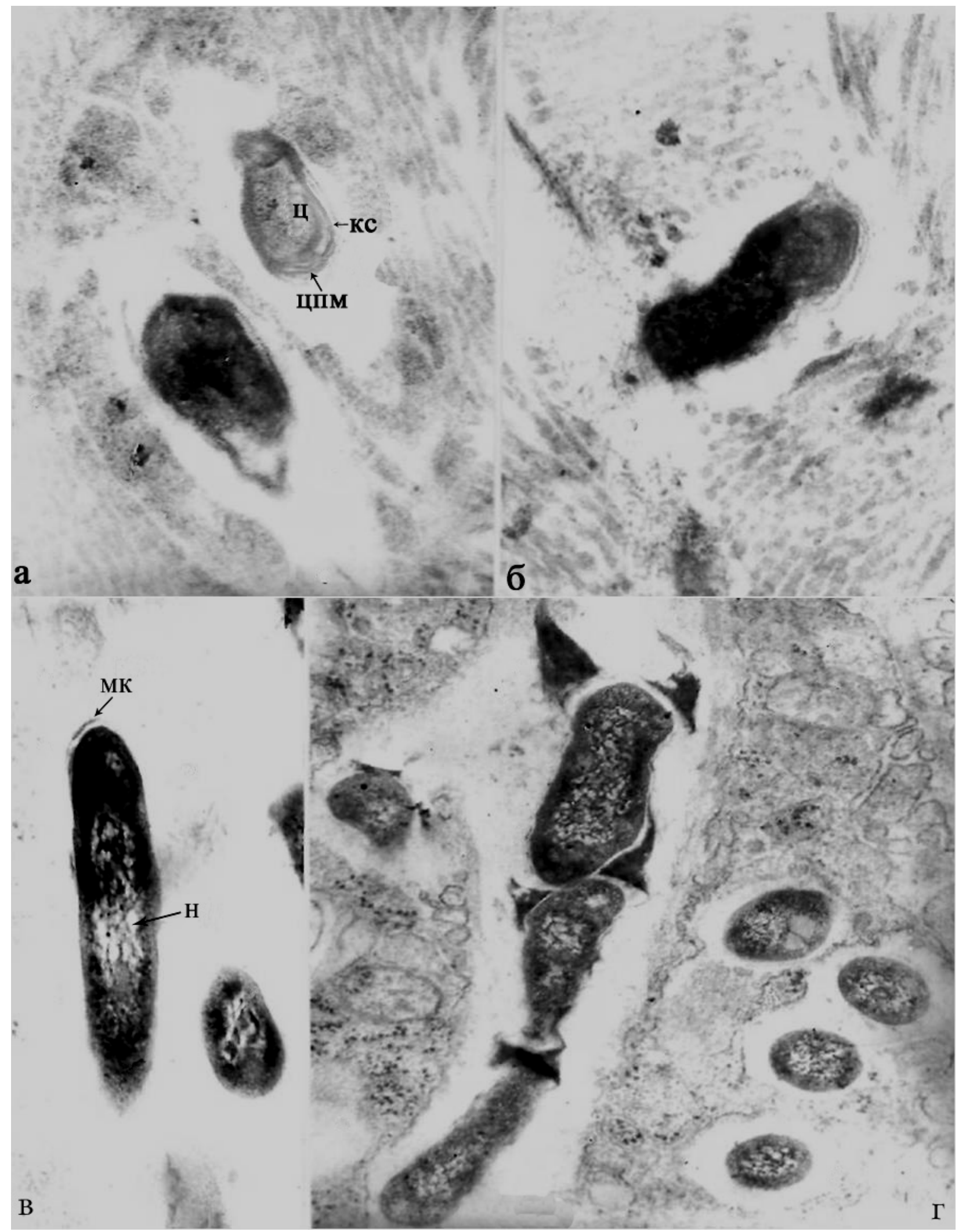

Рис. 29. Покоящиеся формы микобактерий мепры

I пассаж (а, б), II пассаж (в), III пассаж (г). ×20000

Надо также отметить, что в цитоплазме M.leprae 1-го и 2-го пассажей не определялись зерна волютина, характерные Аля исходного штамма. Обнаружено много Аелящихся киеток, причем деление M.leprae 2-го пассажа осуществлялось Авумя способами: путем образования поперечной перегородки, в образовании 
которой принимают участие Аибо только цитоплазматическая мембрана, Аибо одновременно клеточная стенка и цитоплазматическая мембрана, в то время как деление исходного штамма M. leprae происходило путем врастания только цитоплазматической мембраны, не затрагивая клеточную стенку, которая синтезировацась в процессе деления (рис. 29 б).

А^я штаммов M.leprae 3-го пассажа, как и Аля штаммов 2-го пассажа, характерны те же структурные элементы: микрокапсула, клеточная стенка, цитоплазматическая мембрана, выраженный нуклеоил и наличие «гомогенных телец〉 в цитоплазме. ОАнако в отличие от M.leprae 2-го пассажа отмечается значительное количество «гомогенных телец», а также появцяются внутрицитоплазматические гранулы различных размеров высокой электроннооптической плотности - зерна волютина. Обнаружено много Аелящихся клеток. Аеление так же, как и при 2-м пассаже осуществлялось Авумя способами: путем образования перегородки с врастанием как цитоплазматической мембраны, так и всей оболочки (рис. 29 в).

C 3-го пассажа ультраструктура M.leprae стабилизируется и в пределах 8-ми пассажей (срок наблюдения) изменений не отмечено, что, вероятно, может свидетельствовать о «завершении» процесса аАаптации (рис. 29 г).

Таким образом, проведенное исследование показало, что в процессе интраплантарного пассирования M.leprae от человека на мышах (модель Шепарда) происходят изменения в ультратонком строении M.leprae, которые прослеживаются в пределах 3-х пассажей. M.leprae, проходя фазу покоящихся клеток (1-й пассаж), к 3-му пассажу окончательно адаптируются к новому хозяину, о чем свидетельствует отсутствие различий в ультратонком строении бактериальных клеток 3-8 пассажей M.leprae [136].

Из Аанных митературы известно, что при первом пассаже M.leprae интраплантарно на мышах со временем отмечалось уменьшение их количества в мапе и ко 2-му мес. с момента заражения M.leprae в подушечках мап не определялись [101]. Можно предположить, что M.leprae трансформируются в покоящиеся формы и методом Циля-Нельсена не определяются.

Электронно-микроскопические исследования покоящихся форм Аругих микроорганизмов (в частности иерсиний) выявили сходство их ультраструктуры с обнаруженными нами покоящимися формами M.leprae. В экспериментах продемонстрирована реверсия покоящихся форм в вегетативные [70]. Можно предполагать, что переход в покоящееся состояние - один из механизмов, обеспечивающих приспособление M.leprae к резким изменениям условий внешней среды.

Важным признаком адаптации M.leprae к новому хозяину может служить появ ение в клетках зерен волютина. Эти вкцючения не обнаруживались нами в M.leprae 1-2 пассажей на мышах. По мнению исследователей [178], появление волютина или увеличение его количества в бактериальных клетках является показателем аАаптационных возможностей организмов переживать неблагоприятные условия окружающей среды.

Вопрос об изменении биологических свойств M.leprae при пассировании на мабораторных животных важен как с точки зрения их таксономии и систематики, так и возможности использования аАаптированных штаммов M.leprae в качестве 
источника Аля получения специфических биопрепаратов. Возможность фенотипической изменчивости штаммов M.leprae при пассировании in vivo необходимо учитывать при экспериментальном моделировании, а также при скрининге противолепрозных препаратов на модели Шепарда.

\section{6. ПОРАЖЕНИЯ СОСУАОВ ПРИ АЕПРЕ}

Как известно, ведущим фактором тканевых нарушений при Аепре является, в частности, поражения сосудов и колцагеновых волокон соединительной ткани, что играет важную роль в развитии мепрозного процесса [42]. В результате электронно-микроскопического исследования биоптатов пораженной кожи

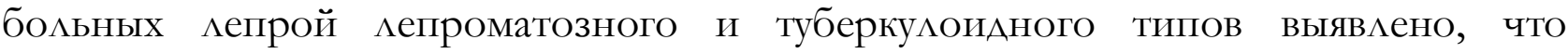
энАотелий капицАяров находится в состоянии относительного покоя. Отмечено некоторое сужение просвета капицляра и утолщение базальной мембраны.

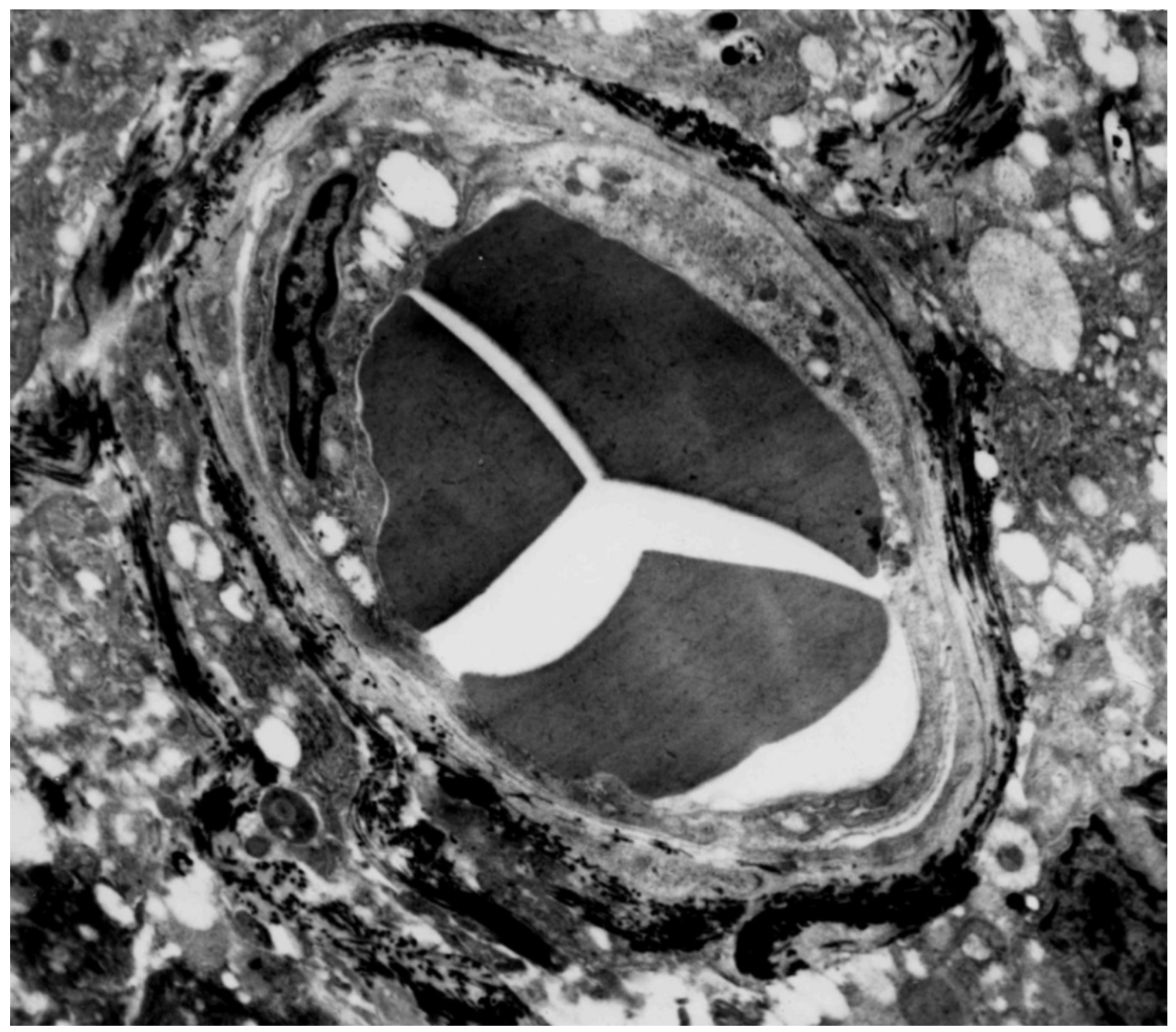

Рис. 30. Эндотелиальные клетки капицляров в состоянии относите $ь$ ього покоя. $\times 10000$

В пораженных тканях больных мепрой мепроматозного типа в активной стадии болезни, в основном, большая часть эндотелиальных клеток сосудов поражена, и клетки в состоянии относительного покоя встречаются крайне реАко. 
Эндотелиальные клетки в состоянии относительного покоя вытянуты в Алину и имеют изрезанные границы. Хроматин распределен равномерно. ЯАерная часть клетки выступает в просвет сосуда. Цитоплазматическая мембрана извитая. Цитоплазма эндотелия содержит большое число пиноцитозных пузырьков. МитохонАрии имеют немного коротких крист.

Значительная часть эндотелиальных клеток пораженных участков кожи находится в состоянии набухания и характеризуется просветлением цитоплазмы. Сохраняется вытянутая форма ядра и изрезанность границ. Наблюдаются глубокие изменения митохондрий (набухание, просветление матрикса, деструкция крист). Гранулярный ретикулум функционально более выражен. Резко возрастает число пиноцитозных пузырьков (рис. 30).

Эндотелиальные клетки часто содержат микобактерии мепры.

Сильно набухший эндотелий может облитерировать просвет капиццяра и полностью тромбировать его (рис. 31 а, б).

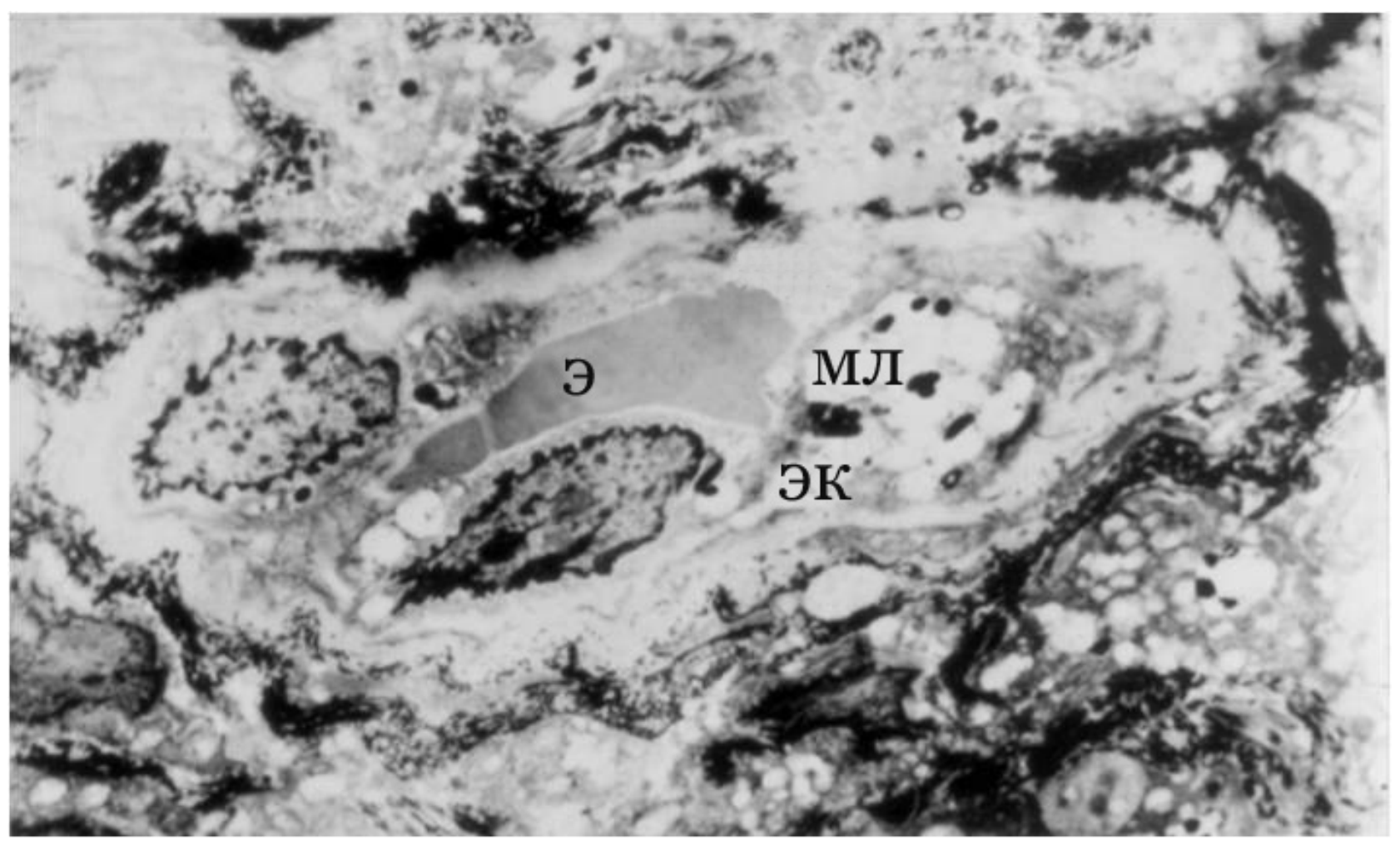

Рис. 31 а. Эндотелиальные клетки содержат M.leprae $\times 6000$ 


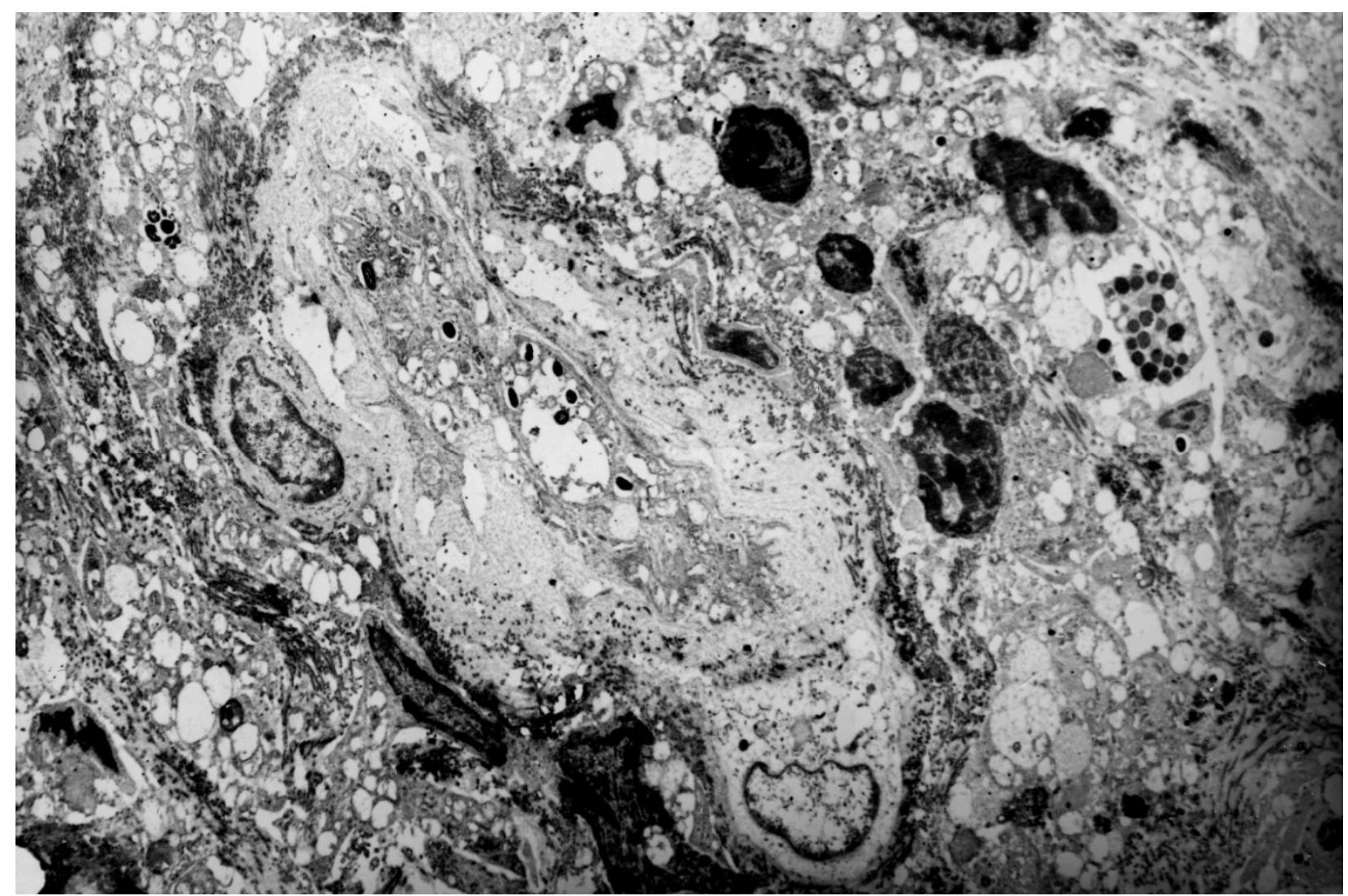

Рис. 31 б. Симьно набухший эндотелий облитерирует просвет капимцяров и полностью тромбирует его. $\times 5000$

Аеструктивные изменения в эндотелиальных клетках, нарастающие под Аействием патогенных факторов, персистенции в эндотелии M.leprae, в конечном итоге приводят к их распаду. Происходит разрыв цитоплазматической мембраны, в результате чего M.leprae вместе с обломками клеток попаАают в просвет сосуда и разносятся током крови (рис. 32 ).

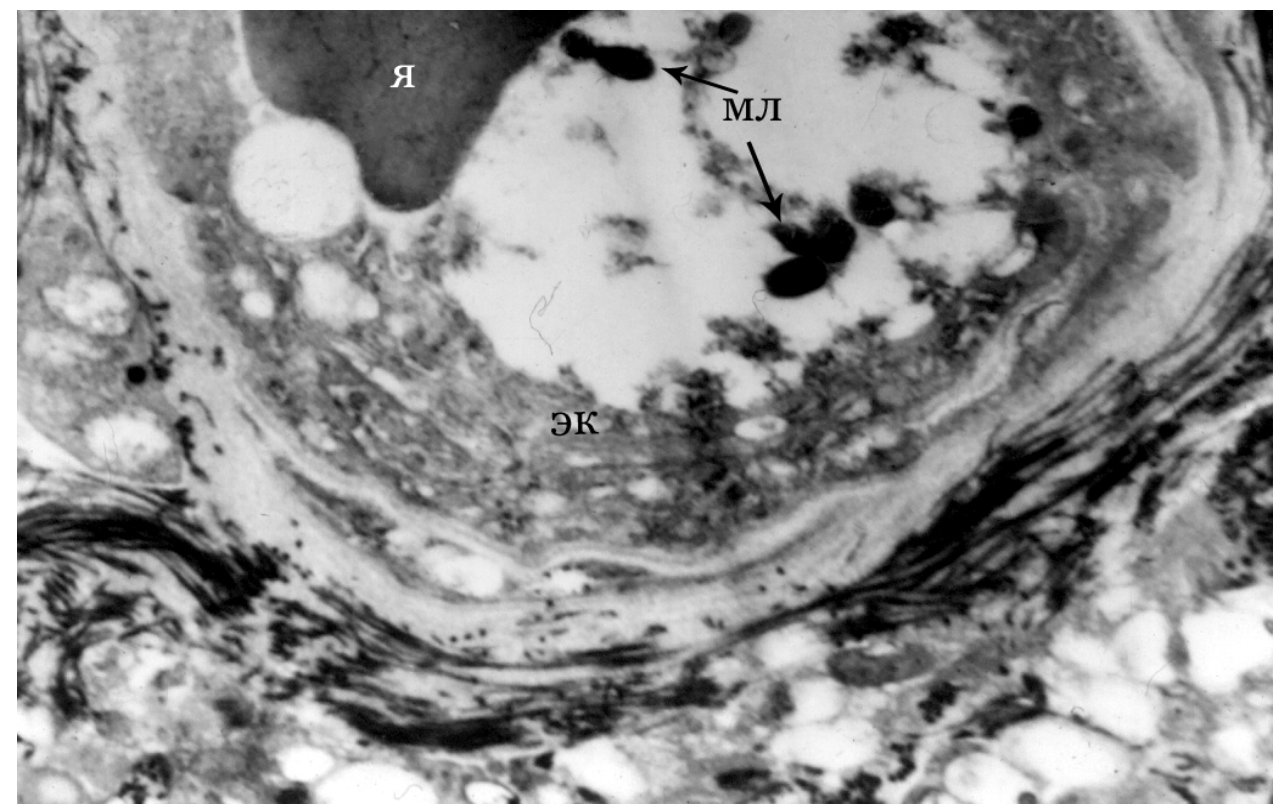

Рис. 32. Распал эндотелиальных клеток с выходом M.leprae в просвет сосуда. $\times 10000$ 
При массовом распале пораженных эндотелиальных клеток может возникнуть явление бактериемии. В этом случае не исключается роль кровососущих насекомых в распространении инфекции (рис. 33) [52].

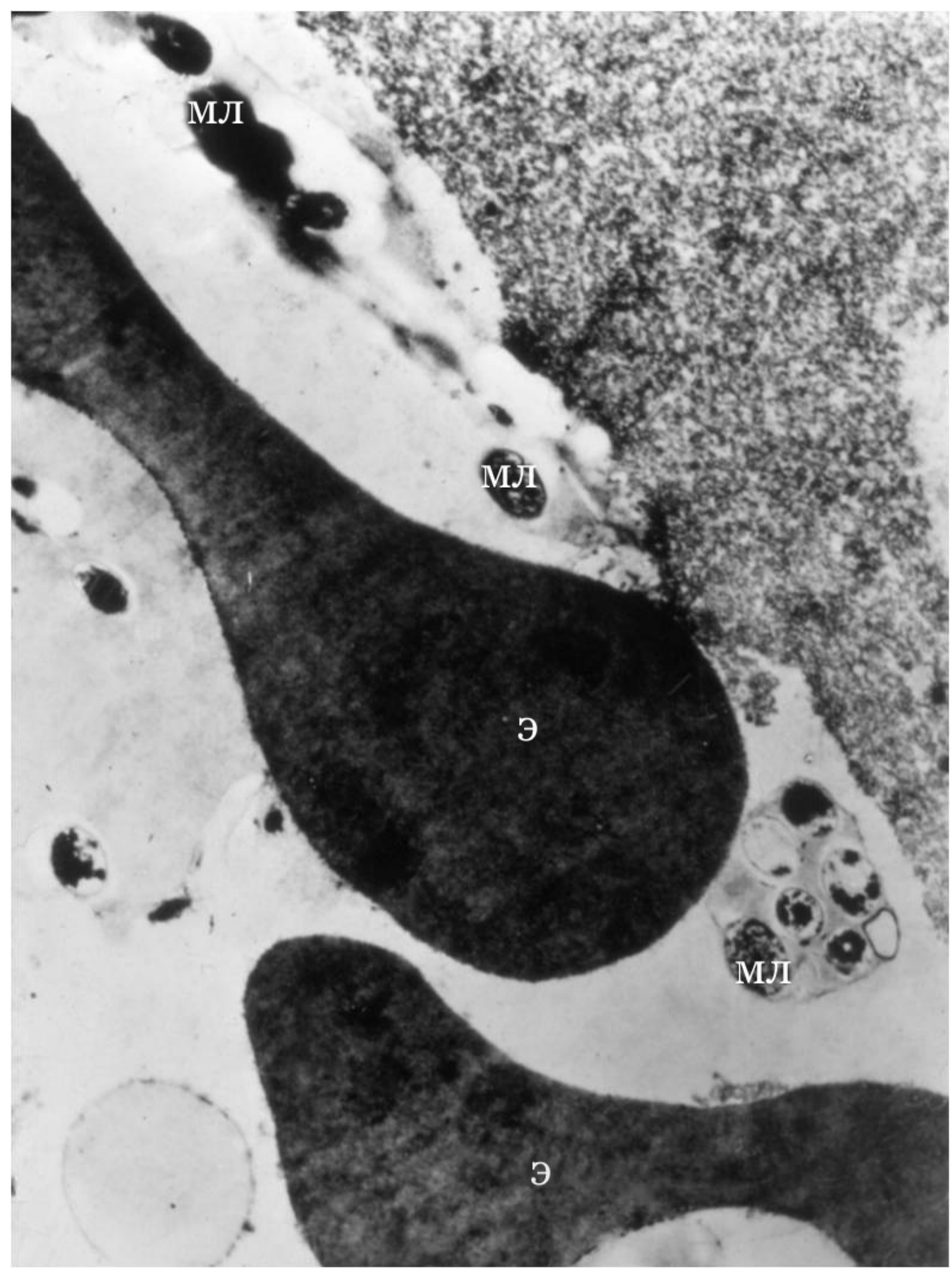

Рис. 33. M.leprae в просвете сосуда. $\times 15000$ 


\section{Б. Mycobacterium tuberculosis}

Аоказательства существования туберкулеза были обнаружены еще при раскопках у человека, жившего за 5 т.л. Ао н.э. в виде Аеформаций грудных позвонков. Аревние врачи описывали в своих работах это заболевание как «чахотка» (в очерках Аристотеля и Гиппократа). В художественной митературе также есть несколько упоминаний на туберкулёзную тематику: Аюма «Аама с камелиями», Чехов «Цветы запоздалые», Короленко «Аети подземелья». Несмотря на научный прогресс, ежегодно в мире туберкулёзом заболевает около 9,5 млн. человек, что составляет 137 на 100 тыс. населения [106]. Туберкулёз остаётся одной из Аоминирующих социально опасных инфекций, склонных к скорейшим генетическим изменениям и возникновению новых форм возбудителей, что ведет к множественной мекарственной устойчивости и возникновению вспышек заболеваемости [161].

\section{1. МОРФОАОГИЯ, ФЕРМЕНТНЫЕ И КУ ЬТУРААЬНЫЕ CВOЙСТВА MYСOВАСТЕRIUM TUBERCULOSIS}

\section{2.}

Mycobacterium tuberculosis, палочка Коха - вил микобактерий, описан 24 марта 1882 года Робертом Кохом (24 марта объявлено ВОЗ Всемирным днем борьбы с туберкулёзом). Мусobacterium tuberculosis входит в группу

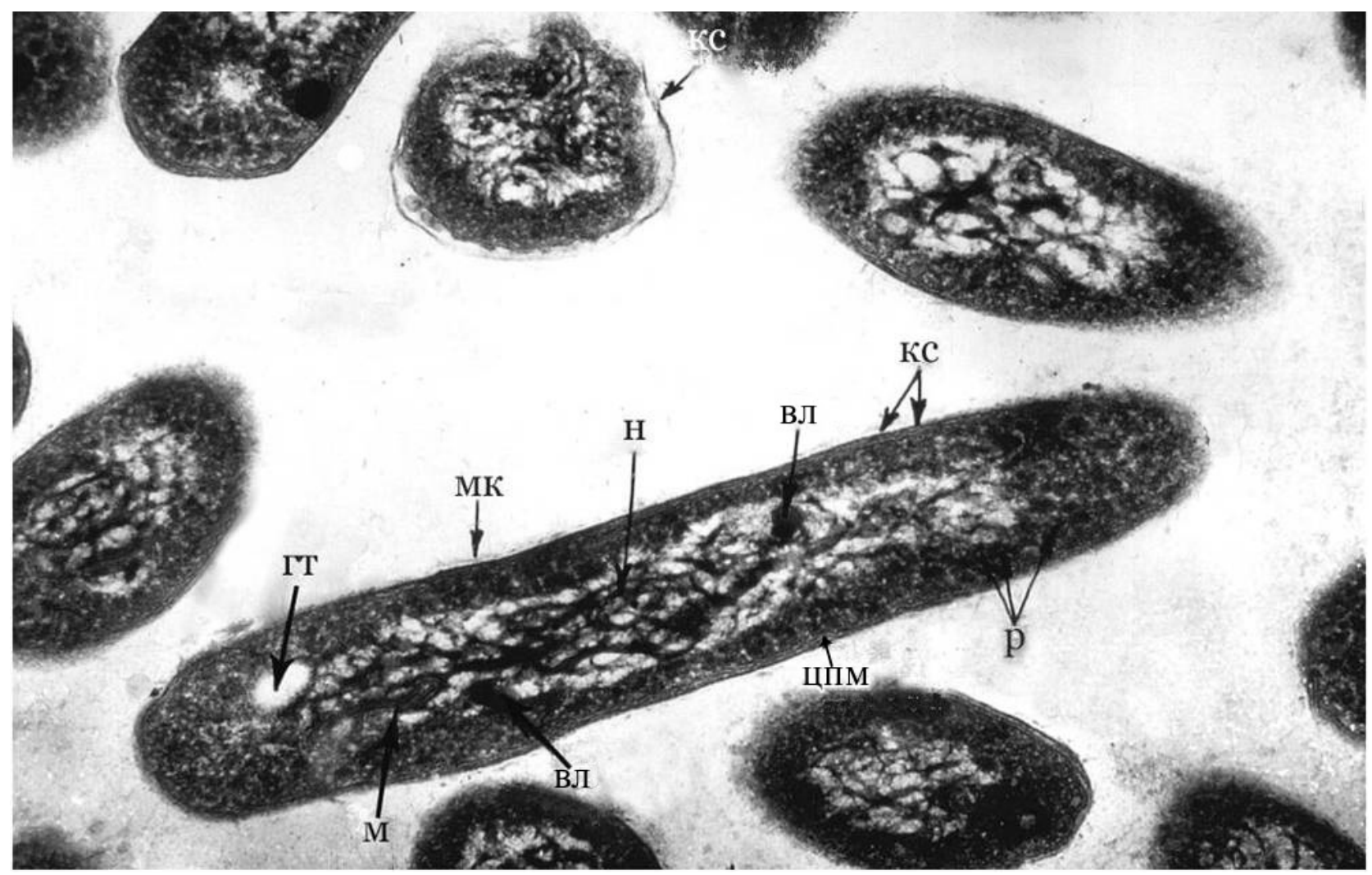

Рис. 34. M.tuberculosis. Общий вид бактерии. × 20000 
близкородственных видов МТВС (Микобактерии туберкулёзного комплекса) (англ. Mycobacterium tuberculosis complex), представители комплекса (M.tuberculosis, M.bovis, M.bovis BCG, M.africanum, M.canettii, M.microti, M.pinnipedii и M.caprae) патогенны Аля человека и животных и вызывают заболевание туберкулёзом у человека и некоторых животных [28]. Наиболее изученным вилом из этого комплекса является Mycobacterium tuberculosis.

Mycobacterium tuberculosis - прямая или слегка изогнутая палочка Алиной от 1 до 5-10 мкм и диаметром поперечника - 0,3-0,6 мкм, характеризующаяся полиморфизмом. В митературе описаны зернистые, гомогенные, булавовидные, нитевидные и ветвящиеся формы с булавовидными утолщениями на концах, Алинные формы в виде грибов (рис. 34) [115]. Форма микобактерий не является постоянной и изменяется под вАиянием внешней среды. Концы клеток микобактерий закруглены. Методом негативного контрастирования показано, что клетки МТ не имеют на своей поверхности каких-цибо выростов, жгутиков или пикей (рис. 35).

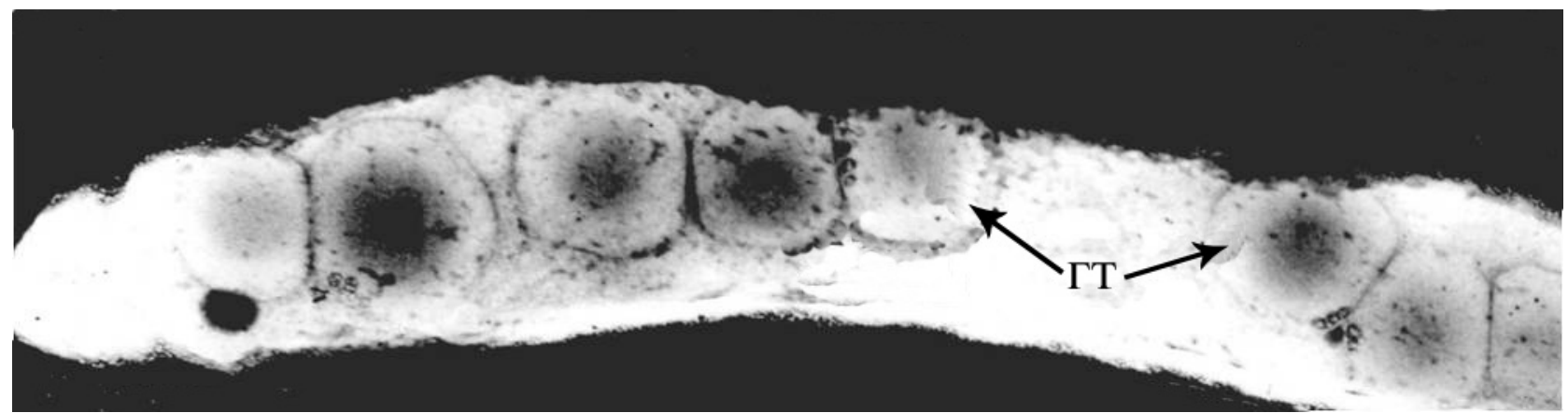

Рис. 35. Негативное контрастирование M.tuberculosis. × 15000

При помощи световой микроскопии в цитоплазме микобактерий туберкулеза обнаружены гранулы больших и малых размеров, имеющие темную окраску. Тинкториально - слабо грамположительные. Аля дифференцирования окрашивают по Цилю-Нельсену или используют окраску флюорохромами. Клетки с характерным свойством кислото- и спиртоустойчивой (на оАной из стаАий роста) окраски явцяются аэрофилами и мезофилами (Аиапазон температур $37-42^{\circ} \mathrm{C}$ ), однако в процессе жизнедеятельности в неблагоприятных условиях метаболизм может измениться, а клетки трансформироваться в микроаэрофилы и даже становиться анаэробами, что предполагает существование у них сложного жизненного цикла [173]. По потреблению кислорода и развитости оксидазных систем микобактерии схожи с истинными грибами. В митературе описаны фильтрующиеся и L-формы микобактерий. Очень мелкие фильтрующиеся формы вылеляются у больных, Алительно принимавших противотуберкулёзные препараты. L-формы имеют сниженный уровень метаболизма и ослабленную вирулентность. Они могут Алительное время персистировать в организме и индуцировать противотуберкулёзный иммунитет [39, 133]. Микобактерии туберкулеза размножаются путем поперечного деления. Растут они Аовольно медленно (одно деление за 14 часов) при температуре $37-42^{\circ} \mathrm{C}$ на искусственных и полусинтетических питательных средах (глицериновых, картофельных, яичных, овощных). Известно, что микобактерии туберкулеза нестрогие аэробы. Они могут 
Аавать рост и поА пленкой масла. В качестве связующего звена межАу НААНАегидрогеназой и цитохромом b в переносящей системе рода Mycobacterium служит витамин В9. Эта система цитохромов напоминает митохондриальную эукариотов. Она чувствительна к Аинитрофенолу, так же как и у высших организмов. Описанный тип дыхания - не единственный источник образования АТФ. Кроме $\mathrm{O}_{2}$-терминальной, микобактерии могут использовать дыхательные цепи, переносящие электроны и оканчивающиеся нитратами $\left(\mathrm{NO}_{3}{ }^{-}\right)$. Резервом Аыхательной системы микобактерий является ещё и глиоксилатный цикл. Бескислородное (эндогенное) Аыхание, проявляющееся в атмосфере с концентрацией кислорода менее 1\%, стимулирует азидные соединения, которые уменьшают окисление пирувата или трегалозы. Но снижение содержания кислорода ведет к замедлению роста. Углекислота в больших количествах отрицательно влияет на рост микобактерий туберкулеза. Микобактерии содержат никотиновую кислоту. Из ферментов - цитохромоксидазу, дегилрогеназу, катацазу, пероксидазу, никотинаминазу, пираминаминазу, нитратредуктазу, арилсульфатазу, эстеразу, мипазу, фосфатазу, $\beta$-галактозилазу, редуктазу. Причем, различные штаммы микобактерий туберкулеза характеризовались неодинаковым энзиматическим спектром [12, 20, 31, 58, 119].

\section{3. УАЬTРАСТРУКТУРА MYCOBACTERIUM TUBERCULOSIS}

Первое электронно-микроскопическое изучение микобактерий туберкулеза было проведено в нашей стране А.И. Каграмановым в 1948 году. Автором изучалась величина и форма целых клеток. Из Аеталей внутреннего строения

отмечены зерна в цитоплазме. F. Basserman (1958) обнаружил в клетках микобактерий туберкулеза полярные электронно-плотные образования, которые трактовац как зерна метафосфата. В цитоплазме микобактерий туберкулеза им обнаружены вакуоли, соответствующие, по его мнению, ядрам. Исслелования отечественных авторов: Э.И. Чертковой и Н.И. Буйнова (1953), Г.Т. Павловского и Н.М. Соколовой (1955), И.С. Покотинского и Ар. (1960), И.К. Цемлариуса (1963), Т.Н. Чайкиной и Г.А. Красникова (1966), Г.Г. Цимбалару (1967) выполнялись на целых клетках. Эти исследования дают мишь общее представление о форме и размерах бактериальных клеток. Более позАние исслелования, выполненные с применением метода ультратонких срезов, показали сложность внутреннего строения клеток микобактерий туберкулеза (рис. 36). На поверхности клеток определяется умеренно электронно-плотный слой, имеющий бахромчатое строение, названный В.В. Ерохиным и Ар. (1972) как «аморфныгй осмиофильныци материал», а А.Н. Кац и др. (1972) - «микрокапсула». Этот слой, по мнению А.Н. Кац с соавторами (1972), возможно, содержит корА-фактор (вещество, определяющее специфические свойства микобактерий). Микрокапсула бывает весьма вариабельной по толщине и по виду, что зависит от содержания определенных веществ. Окрашивание данного слоя рутением красным оказывает на присутствие в нем полисахаридов (рис. 37). 


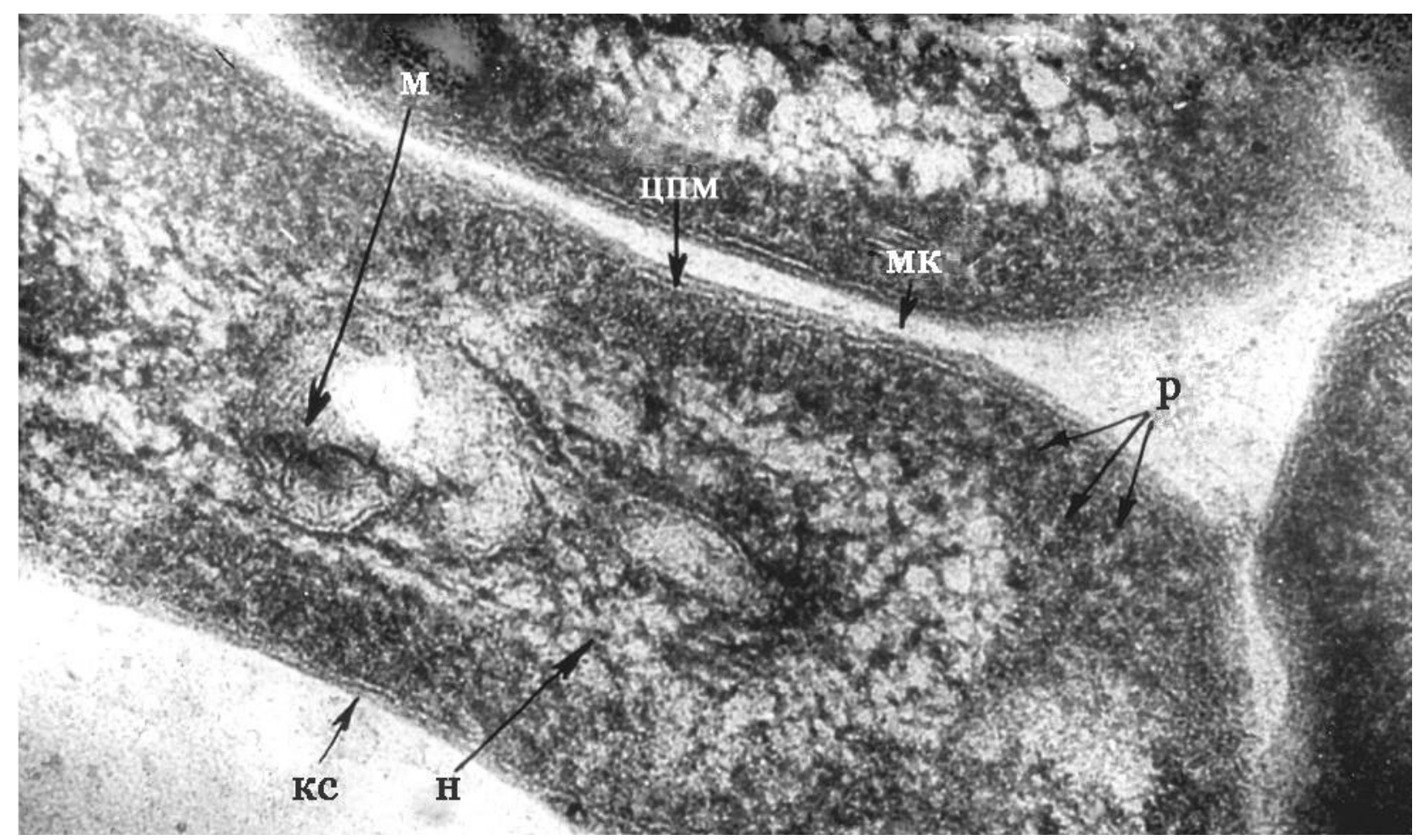

Рис. 36. Строение M.tuberculosis. $\times 20000$

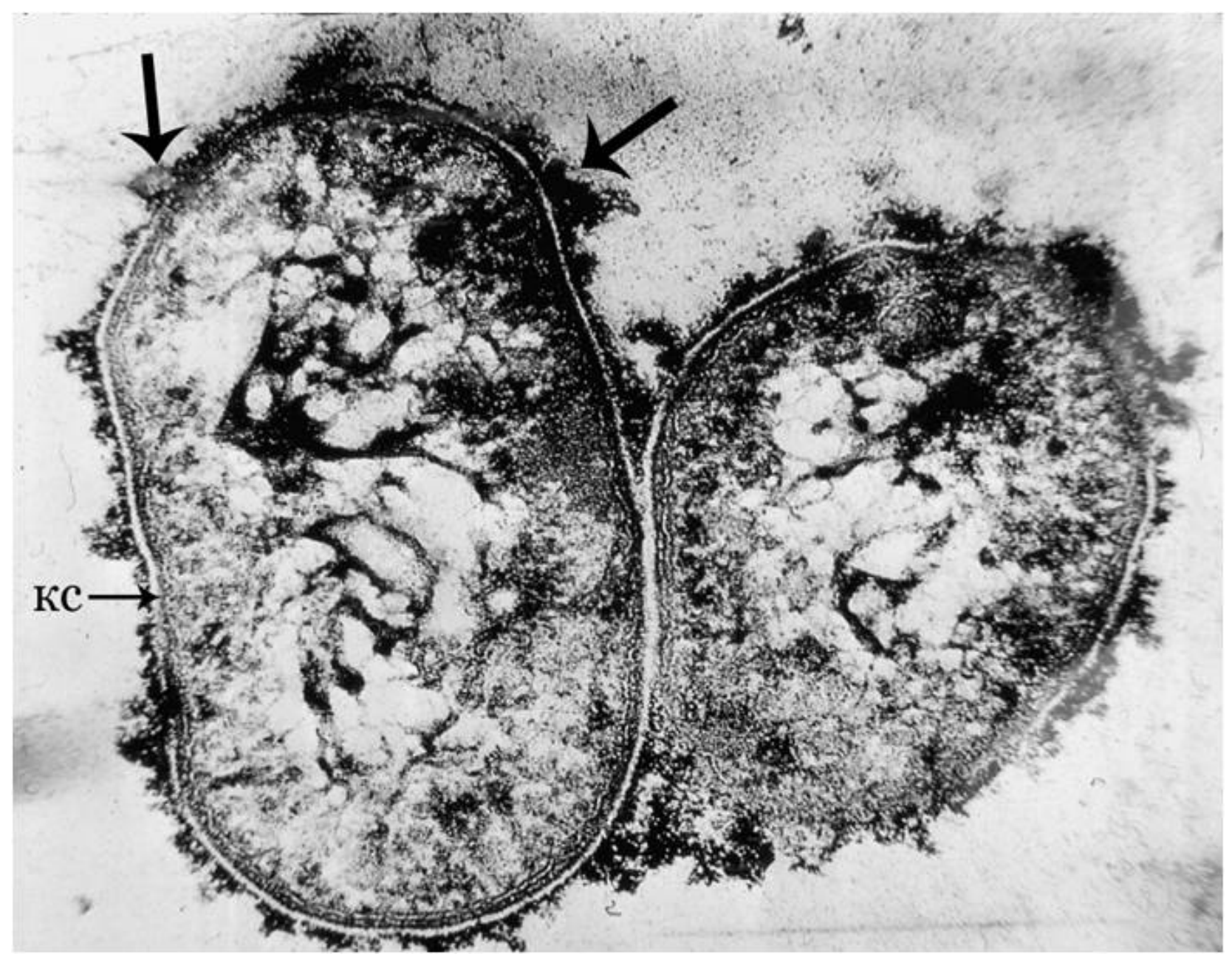

Рис. 37. Отложение рутениевого красного в микрокапсуле M.tuberculosis $\times 20000$ 
Под микрокапсулой находится электронно-прозрачный слой клеточной стенки $[2,32]$. Этот слой более широкий и образован арабиногалактан-миколатоммипополисахаридом, формирующим наиболее значительную часть стенок микобактерий [10]. Его прозрачность Аля электронов, скорее всего, объясняется высокой гидрофобностью этого вещества, а также недостаточным содержанием реактивных химических групп, способных связывать красители (рис. 37)

Электронно-плотная часть клеточной стенки выявлялась в виле оАноконтурного электронно-плотного образования, тесно прицегающего к наружному слою цитоплазматической мембраны. Биохимическими и электронномикроскопическими методами Аоказано, что видимая однослойная электронноплотная часть клеточной стенки фактически состоит из двух слоев, неодинаковых по химическому составу. Наружный слой имеет мипополисахариАо-липиАопротеиновую природу. Полисахариды в этом слое преАставлены маннозой, гАюкозой, галактозой и арабинозой. Внутренний слой содержит мипополисахаридо-мукопептидный комплекс [122]. По мнению П.Аж. Бреннана и Ф. Арепера, пептидогликан-арабиногалактан миколат формирует так называемый скелет клеточной стенки [10]. С ним связано большое число разАичных АипиАов, гАиколипидов и протеинов. Их состав существенно отАичается у разАичных виАов микобактерий, но анатомическую структуру M.tuberculosis не изменяет, и вАияние его на ультраструктуру остается неясным.

К^еточная стенка защищает микобактерию от воздействия внешней среды, обладает антигенными свойствами и проявляет серологическую активность; ограничивает микобактерию снаружи, обеспечивает стабильность размеров и формы клетки, механическую, осмотическую и химическую защиту, включает факторы вирулентности - липополисахариАы, с фосфатиАной фракцией которых связывают вирулентность микобактерий.

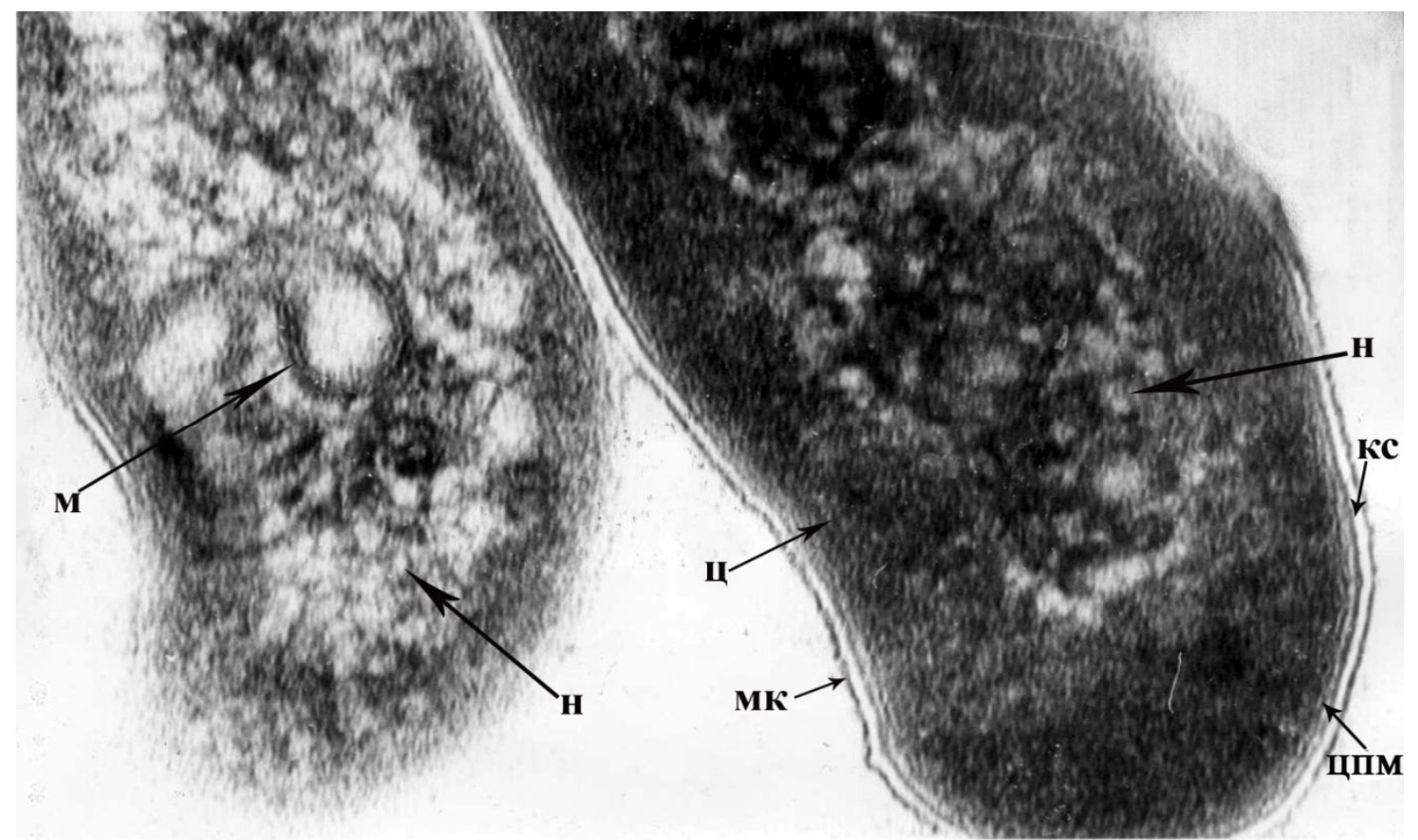

Рис. 38. Цитоплазматическая мембрана M.tuberculosis. × 20000 
Цитоплазматическая мембрана состоит из Авух электронно-плотных слоев, разделенных электронно-прозрачным слоем. Общая толщина ее 7,5-8 нм (рис. 36, 38) $[24,25,32]$.

Хроматиновые структуры (АНК), выявляющиеся на ультратонких срезах в виде нитей, выполняют функции ялра. Электронно-прозрачная зона, заключающая хроматиновые структуры (нуклеоил), не ограничена мембраной от окружающей цитоплазмы [57]. Аиаметр нити нуклеоила составил приблизительно 3 нм. Цитоплазма клеток микобактерий туберкулеза содержит рибосомы и включения: различных размеров сферические гранулы, непроницаемые Аля электронов (зерна метафосфата); электронно-прозрачные вакуоли, ограниченные мембраной (включения мипидов, экстрагированных из клетки в процессе препарирования), и гранулы с умеренной электронной плотностью («гомогенные тельца») (рис.39) [24, 25, 127, 132].

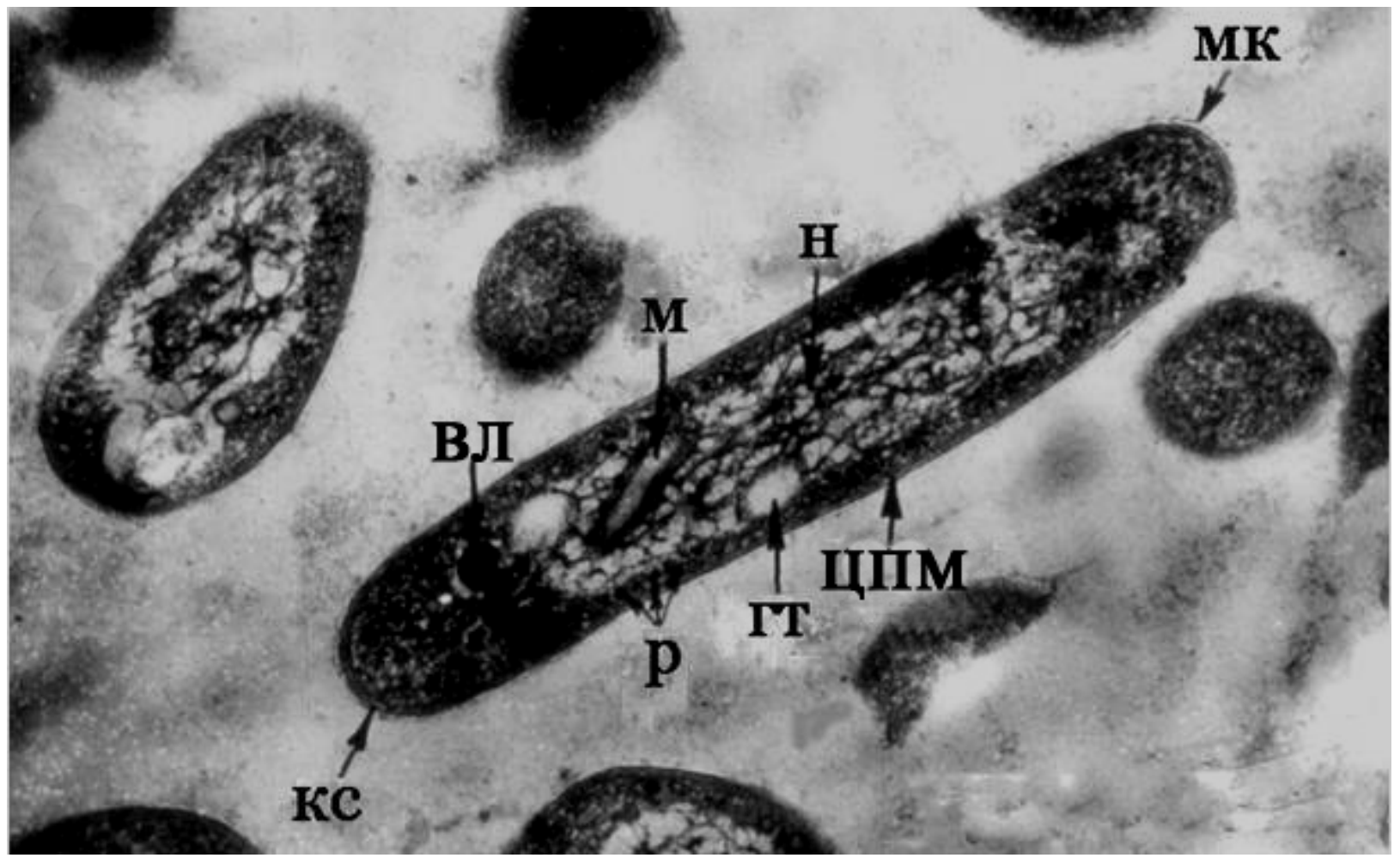

Рис. 39. ГТ M.tuberculosis. × 15000

Цитоплазматическая мембрана вкАючает мипопротеиновые комплексы, ферментные системы, формирует внутрицитоплазматическую мембранную систему (мезосому). Мезосома имеет мамелярное, везикулярное или трубчатовезикулярное строение (рис. 36, 39, 40) [2]. Мезосомы часто обнаруживаются около перегородки деления бактерии и часто связаны с ней и нуклеоилом [24, 33, 158]. Аеление микобактерий туберкулеза осуществляется путем врастания поперечной перегородки от периферии к центру клетки (рис. 41) [24, 25, 32]. Кроме того, Аеление микобактерий туберкулеза может осуществляться путем перетяжки [2, 32]. Как сообщали А.А. Авакян с соавторами (1972), деление микобактерий туберкулеза может происходить путем «растрескивания» цитоплазмы в центре бактериальной клетки, и в Аальнейшем формирование 
перегородки происходит от центра к периферии. Цикл деления - 14-18 часов. Иногда размножение происходит почкованием, редко ветвлением.

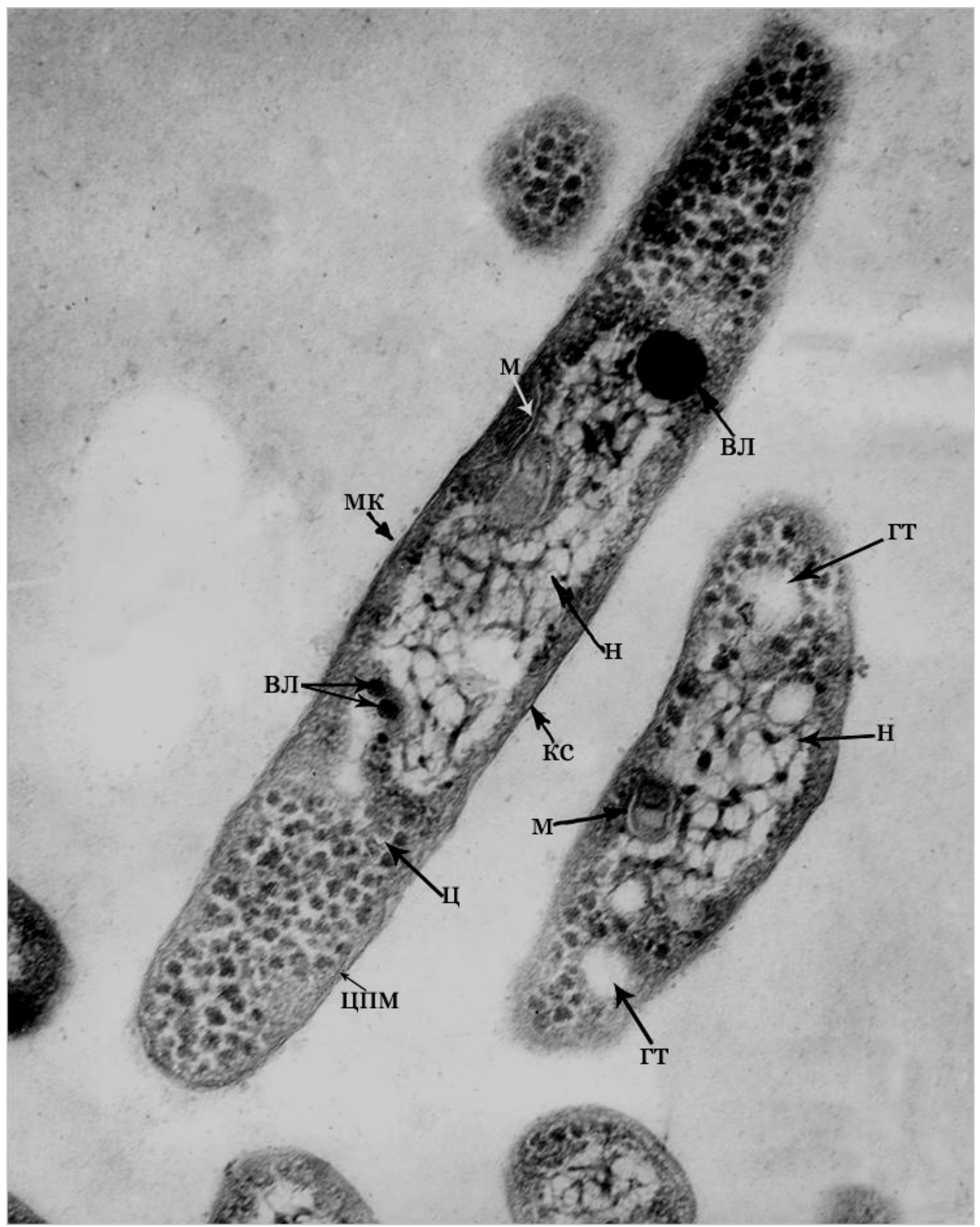

Рис. 40. Мезосома M.tuberculosis. $\times 15000$ 


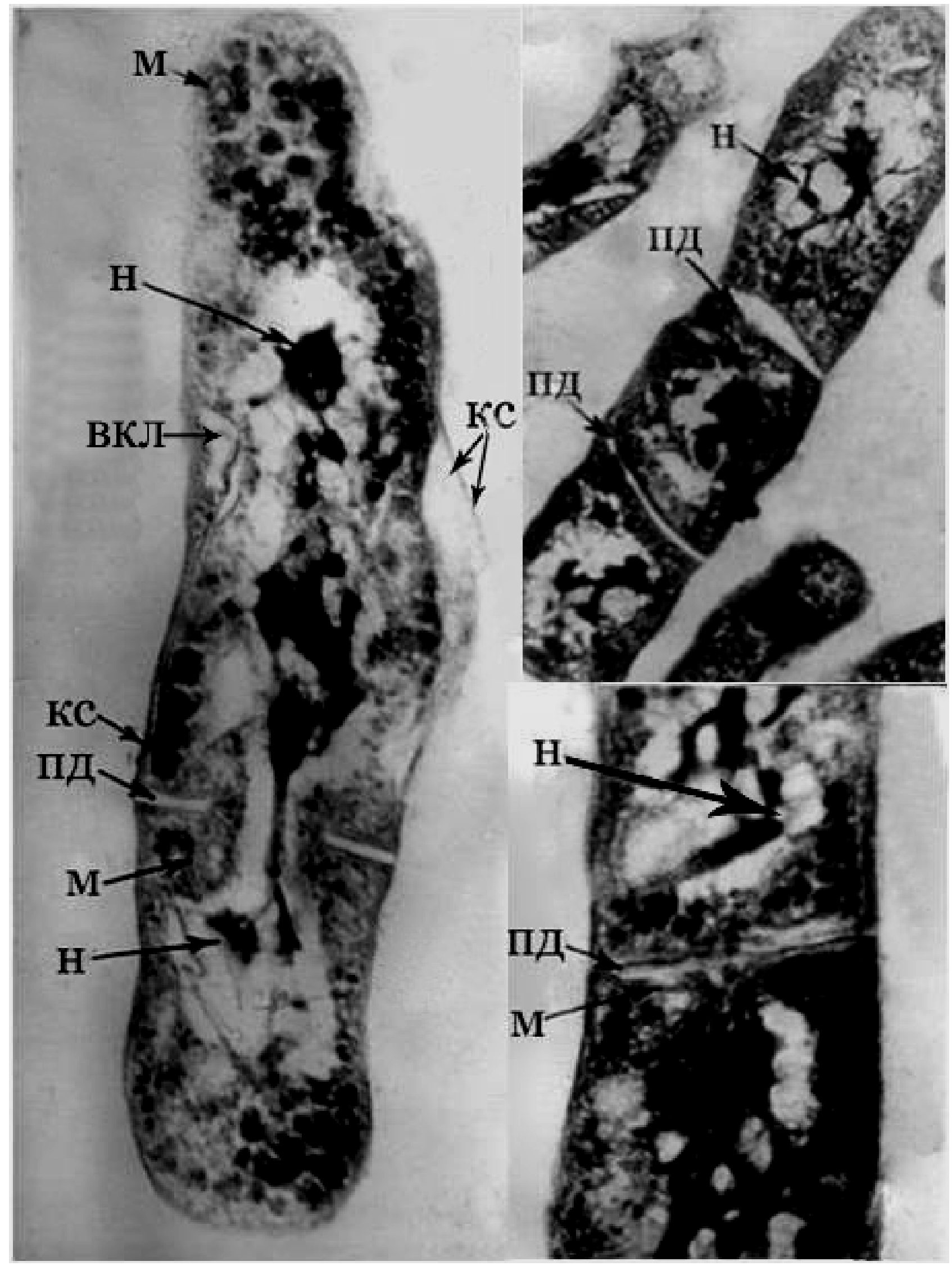

Рис. 41. Аеление M.tuberculosis. × 15000 


\section{4. ЭАЕКТРОННО-ЦИТОХИМИЧЕСКОЕ ИЗУЧЕНИЕ MYCOBACTERIUM TUBERCULOSIS}

В клетках М' кислые мукополисахариды (гликозаминогликаны) маркируются отложениями рутениевого красного, выяв яются, в основном, в области микрокапсулы и имеют фибриццярный виА (Рис. 37). Толщина слоя варьировала от 10 до 45 нм. Рутениевый красный отклалывается в электронноплотных слоях клеточной стенки, наружном слое цитоплазматической мембраны и внутреннем слое мезосом, а также в виле отдельных гранул в цитоплазме бактериальных клеток (рис. 42 б). Методом Т. Kobayasi, Y.Asboe-Hansen (1971) подтвержАено отложение рутениевого красного в области клеточной стенки, цитоплазматической мембраны и цитоплазме (рис. 42 в), что согласуется с мнениями о синтезе материала клеточной стенки мезосомами бактерий.

Контрольные опыты с предварительной обработкой материала гиалуронидазой показали значительное снижение интенсивности отложения рутениевого красного, что предполагает основное содержание в выявленном слое гиалуроновой кислоты (рис. 42 г). В качестве контроля использовался также материал, не обработанный рутениевым красным (рис. 42 а).

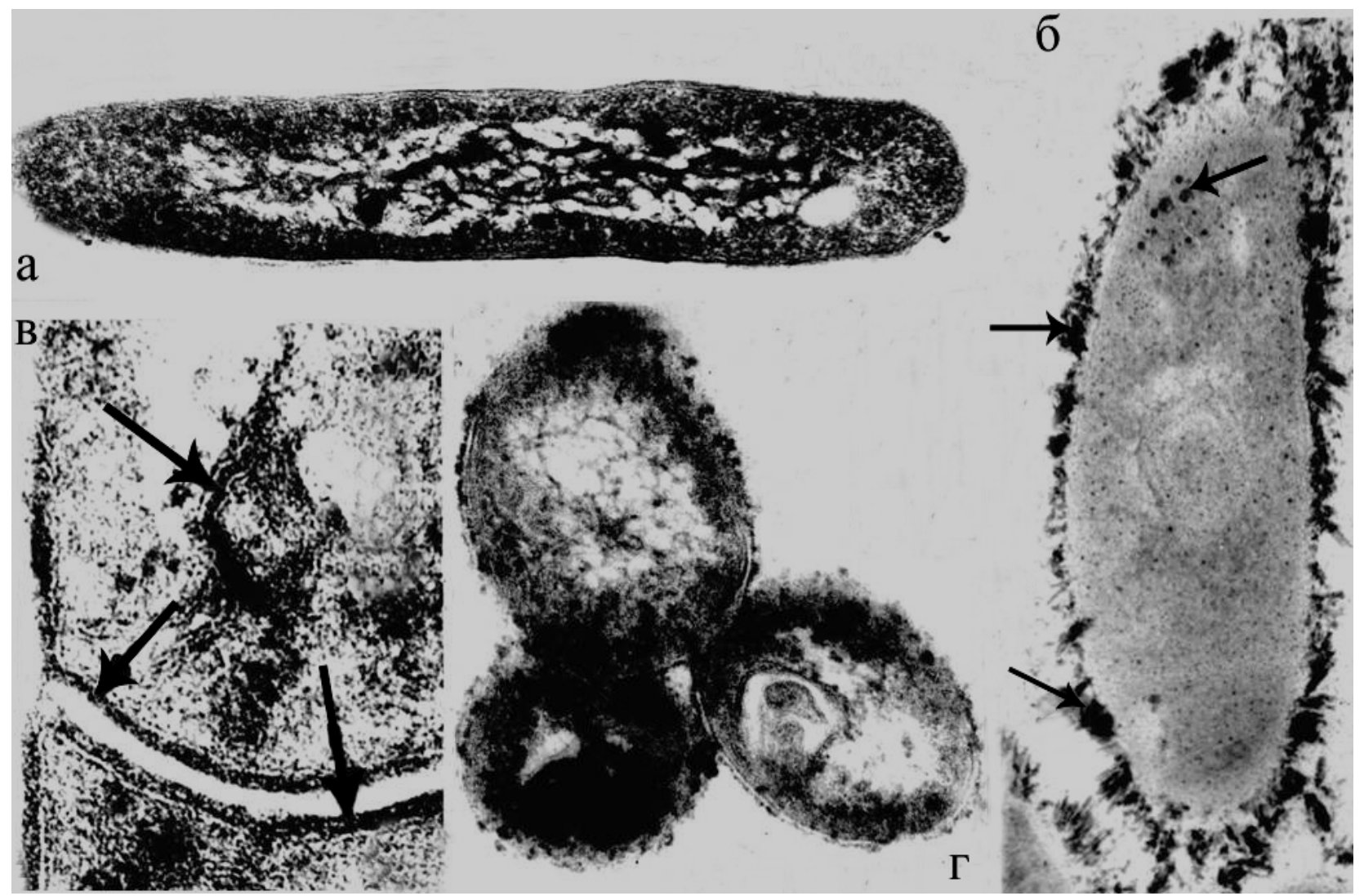

Рис. 42. Срез клетки M.tuberculosis, не обработанный рутениевым красным (a).

Отложение рутениевого красного (стрелки) в цитоплазме (б), в мезосомах, цитоплазматической мембране и клеточной стенке M.tuberculosis (в). КАетки

M.tuberculosis, предварительно обработанные гиалуронидазой (г). × 20000 
Цитоплазма клеток M.tuberculosis плотно заполнена гранулярным компонентом. Содержит «гомогенные тельца» - округлые гранулы, умеренной электронной плотности (рис. 39, 40). Методами электронной цитохимии показано присутствие в них АТФ-азы, что может служить доказательством, что эти образования явАяются запасными питательными веществами микобактерий.

У МТ продукт полимеризации окислительного ААБ, маркирующий места активности цитохромоксидазы, пероксидазы, НААН-диафоразы и сукцинатдегиАрогеназы, выяв ялся в виле электронно-плотного вещества, располагающегося в области наружного слоя ЦПМ, а в области М во внутреннем слое, являющимся продолжением наружного слоя ЦПМ (рис. 43, 44, 45). Интенсивность реакции на М оказалась более выраженной. Следует отметить, что интенсивность отложений диаминобензилина (ААБ), а следовательно и активность цитохромоксидазы, пероксилазы, НААН-диафоразы и сукцинатдегидрогеназы у M.tuberculosis выше, чем у M.leprae (рис. 15).

Контрольные опыты с инкубацией материала в средах с добавлением цианида натрия и без ААБ (рис. 43 б, 44 б) показали отсутствие электронноплотных отложений в области цитоплазматической мембраны и мезосом микобактерий, что свидетельствует о специфичности реакции.

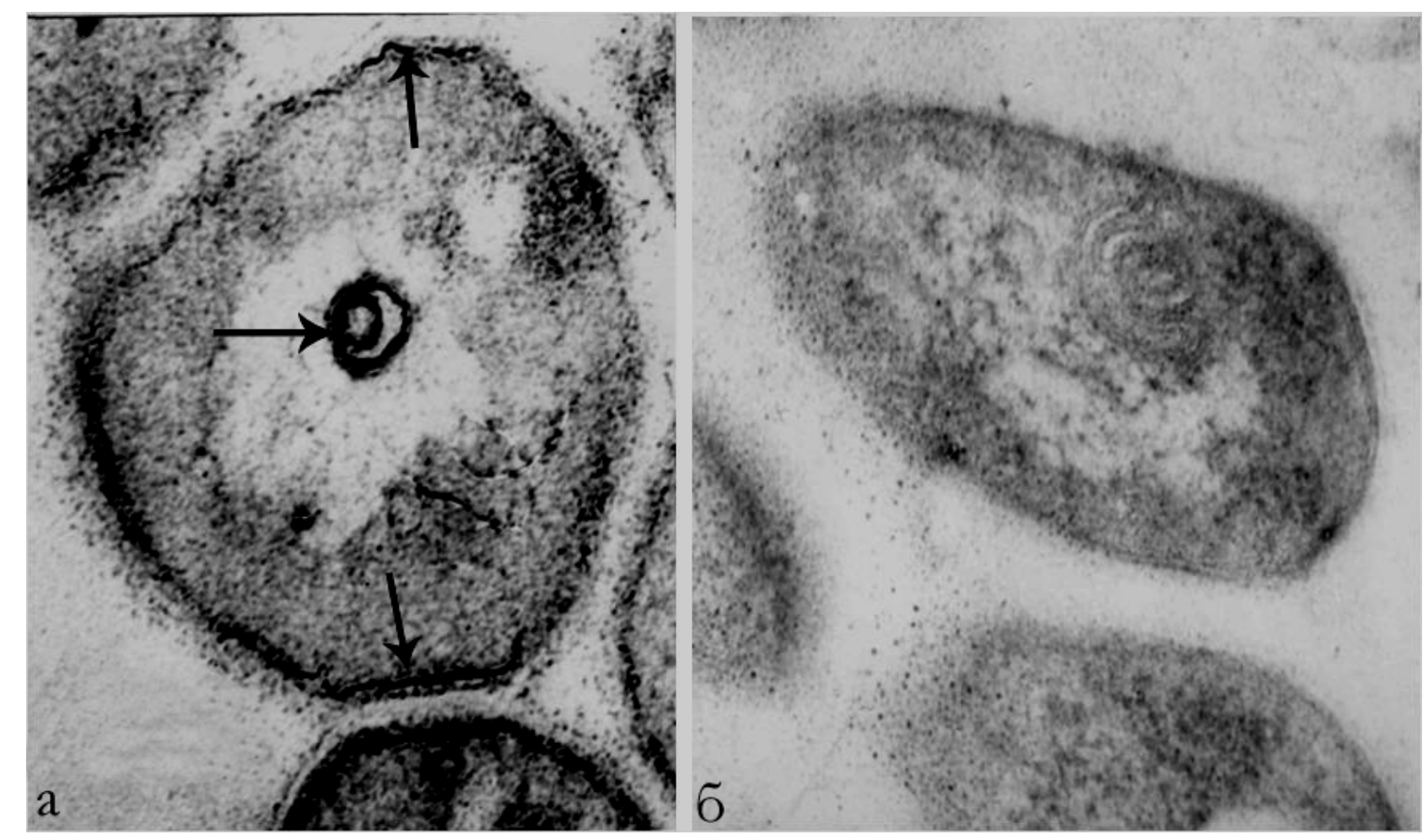

Рис. 43. Отложение ААБ (стрелки), маркирующие места активности цитохромоксидазы в клетках M.tuberculosis (a). Срезы клеток M.tuberculosis, инкубированные в среде с цианилом и среде без ААБ (б) $\times 20000$ 


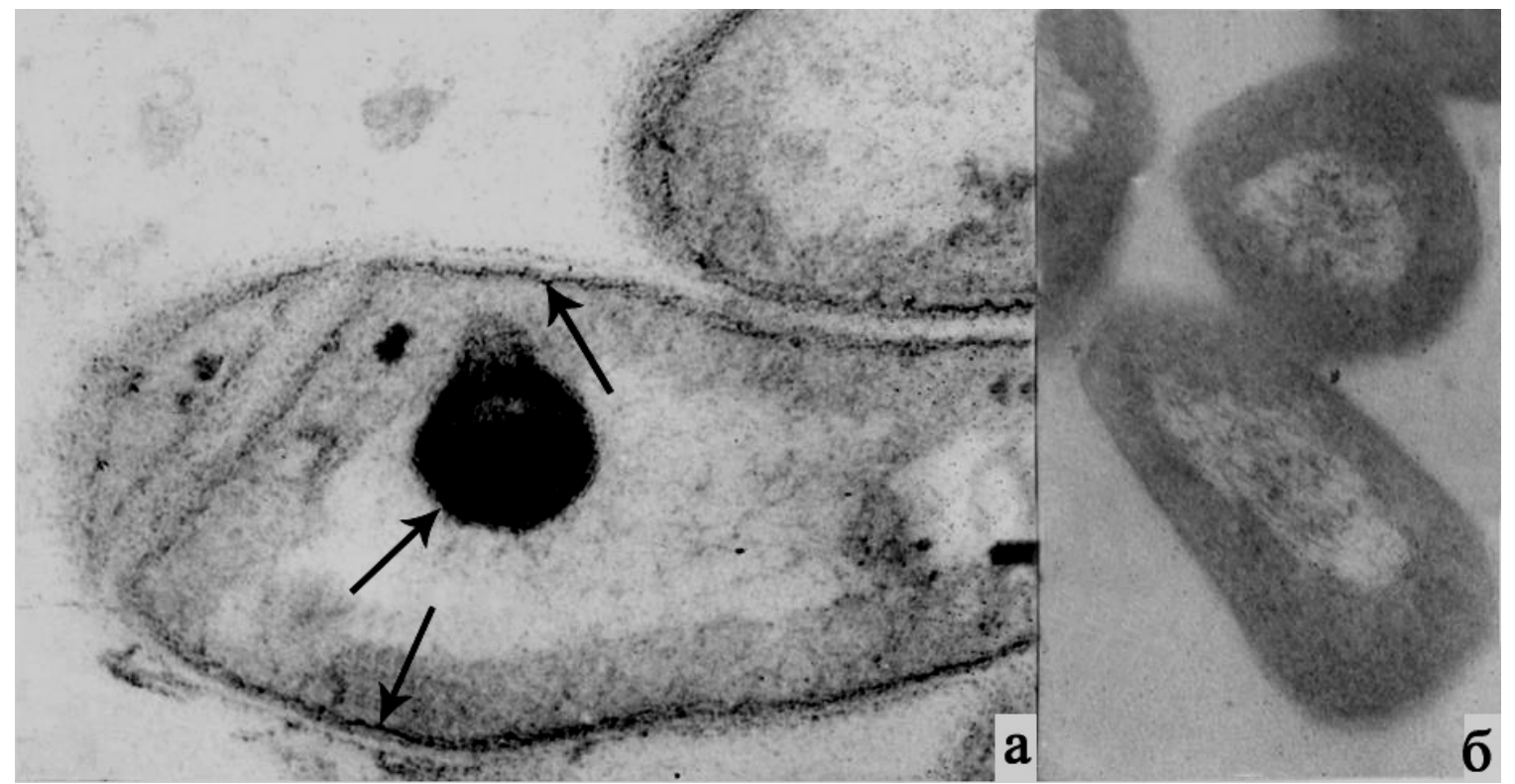

Рис. 44. Отложение ААБ (стрелки), маркирующие места активности пероксидазы в клетках M.tuberculosis (a). Срезы клеток M.tuberculosis, инкубированные в среде с цианидом и среде без ААБ (б) $\times 20000$
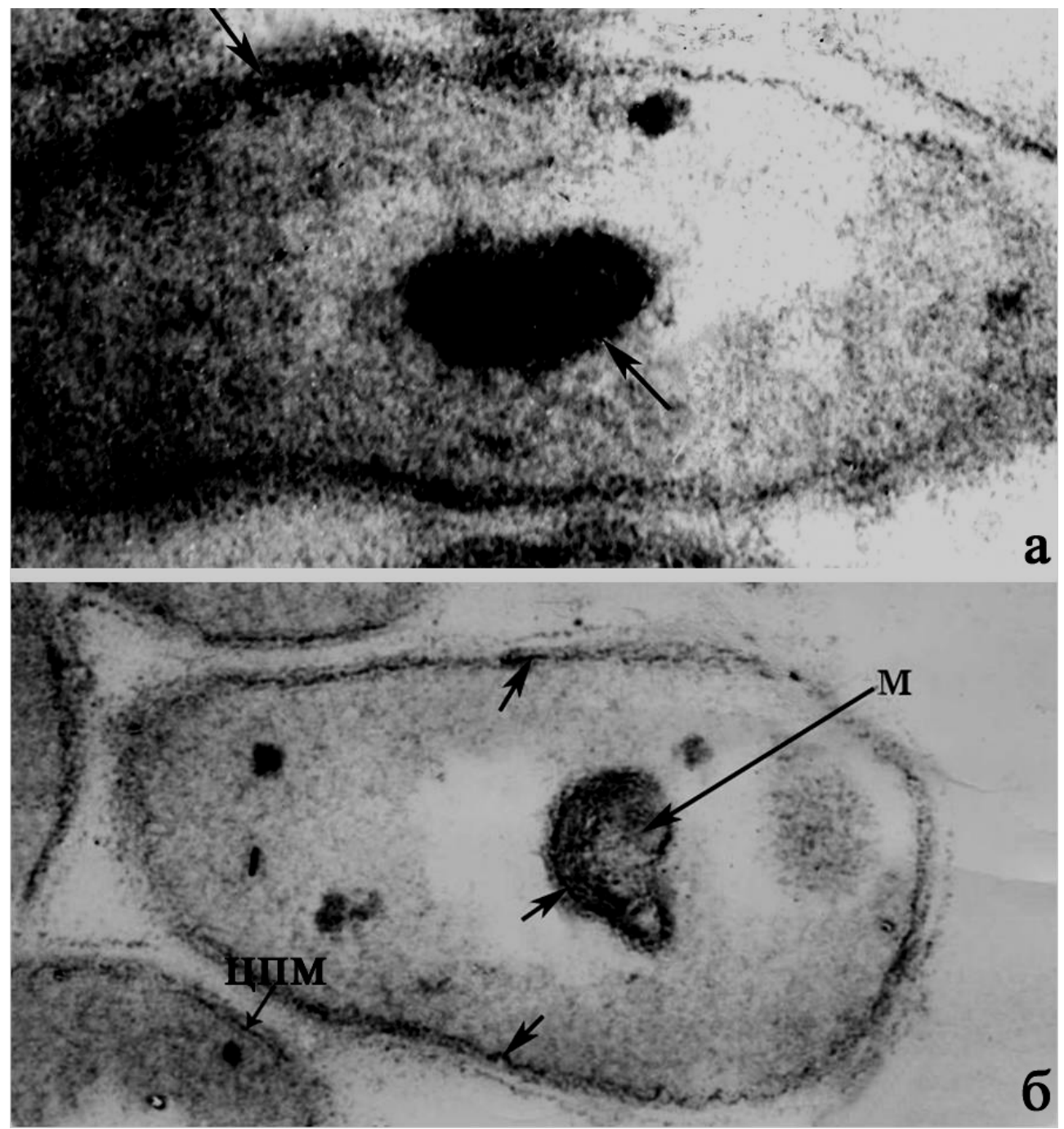

Рис. 45. Отложение ААБ (стрелки), маркирующие места активности НААНАиафоразы (а) и сукцинатдегилрогеназы (б) в клетках M.tuberculosis. × 20000 
У M. tuberculosis активность ДОФА-оксидазы отсутствовала.

Вследствие неблагоприятных воздействий на некоторые культуры микобактерий туберкулеза возникают некислотоустойчивые микроорганизмы, стойко сохраняющие свои свойства при пересевах и, следовательно, являющиеся результатом генетических изменений.

Реверсия некислотоустойчивых форм в кислотоустойчивые происходит так же редко, как возникновение самих форм. Иногда реверсия приводит к появлению типичных, вирулентных туберкулезных микобактерий, а иногАа - нетуберкулезных микобактерий (атипичных), не вирулентных Аля морских свинок [12]. 


\section{B. Mycobacterium kansasii, Mycobacterium marinum, Mycobacterium skrofulaseum, Mycobacterium avium, Mycobacterium intracellulare, Mycobacterium smegmatis}

Актуальность участия нетуберкулезных микобактерий (НТМБ) в развитии воспаления до недавнего времени не обсужАалось: до начала прошлого века НТМБ рассматривали как микробы, колонизирующие организм человека. С 1990-х гг. ХХ в. во многих странах отмечен рост вызванных НТМБ заболеваний - микобактериозов (МБ), что связывают с нарастанием количества случаев ВИЧинфекций $[98,109,174]$. Рост МБ мегких во многих странах сопровожАается снижением заболеваемости туберкулезом [84]. Обусловлено это сходством антигенной структуры МТ и НТМБ, генетической «преАрасположенностью» к туберкулезу и МБ; снижение темпов распространения туберкулеза увеличивает «нишу» ААя МБ.

КАиническое распознание МБ связано с трудностями видовой иАентификации НТМБ, сходной с туберкулезом кАинической, рентгенологической, морфологической картиной вызываемых ими заболевания $[110$, 169]. Часть больных МБ причисляют к больным туберкулезом с множественной мекарственной устойчивостью (М $\Lambda$ ) [137] возбудителя, а часть больных находится под наблюдением по поводу неспецифических воспалительных заболеваний мегких, не получая Аолжного Аечения.

\section{1. МОРФОАОГИЯ, ФЕРМЕНТНЫЕ И КУ АЬТУРА ЬНЫЕ СВОЙСТВА ПРЕАСТАВИТЕ АЕЙ НЕТУБЕРКУ АЕЗНЫХ МИКОБАКТЕРИЙ}

К настоящему времени на основании анализа нуклеиновых кислот, количественной таксономии и серологических методов исследования установлено, что НТМБ являются самостоятельными видами, а не результатом изменчивости МТ [65].

Согласно классификации E.N. Ranyon (1959) на основе культуральных разАичий и продукции пигмента колониями вылемяют 4 группы микобактерий:

Фотохромогенные (Группа I). Эти микроорганизмы характеризуются медленным ростом, не пигментированные при выращивании в темноте, но приобретающие ярко-жёлтую или жёлто-оранжевую пигментацию после вылерживания или реинкубации на свету. К этой группе относятся M.kansasii, M.marinum, M.simiae, M.asiaticum и некоторые Аругие менее патогенные Аля человека.

Скотохромогенные (Группа II). К этой группе относят микобактерии, образующие пигмент как в темноте, так и на свету. На свету цвет колоний более выражен. Микроорганизмы медленно растут на питательных средах (30-60 Аней). Ко II группе принадлежат M. scrofulaceum, M. gordonae, M. xenopi, M. szulgai. 
Нефотохромогенные микобактерии (Группа III). К этой группе относят микобактерии, не образующие пигмент или имеющие бледно-жёлтую окраску, которая не усиливается на свету. Растут в течение 2-3 или 5-6 неА. Потенциально патогенными в этой группе явАяются M.avium, M.intracellulare, M.ulcerans, M.malmoense и Ар.

Быстрорастущие микобактерии (Группа IV). Микобактерии, относящиеся к этой группе, характеризуются быстрым ростом (Ао 7-10 Аней) в виде пигментных или беспигментных колоний, чаще R-формы. K 4 группе, по Ranyon, относятся M.phlei, M.smegmatis, M.fortuitum, M.abscessus и др.

Все они представляют собой палочки с закругленными концами, отличающиеся полиморфизмом, и окрашиваются по методу Циля-Нельсена в красный цвет. Микобактерии аэробны и неподвижны (исключая виА Mycobacterium marinum, который демонстрирует подвижность вне макрофагов) и характеризуются кислото- и спиртоустойчивостью [9]. Микобактерии не содержат спор и капсул, и их принято считать грамположительными бактериями. Микобактерии не явАяются грамположительными бактериями с эмпирической точки зрения, но они классифицируются как кислотоустойчивые грамположительные бактерии. В ходе эволюции микобактерии выработали разАичные механизмы преодоления или инактивации неблагоприятных факторов внешней среды. Во-первых, это особая клеточная стенка. Во-вторых, это обширные метаболические возможности. Они способны инактивировать многие клеточные токсины и вещества (различные перекиси, альдегилы и Аругие), разрушающие клеточную оболочку. В-третьих, это морфологическая пластичность, заключающаяся в трансформации микобактерий (образование Lформ, Аормантных клеток). По своей устойчивости, после спорообразующих бактерий, они занимают мидирующее место в царстве прокариот. Клетки сохраняют свою жизнеспособность в сухом состоянии до 3 мет. При нагревании некоторые виды микобактерий могут выдерживать температуру существенно выше $80^{\circ}$ С. Микобактерии проявцяют устойчивость к возАействию спиртов и ацетона. Отмечено, что средства на основе четвертичного аммония не проявцяют антимикобактериальной активности. В опреАелённых условиях концентрации радикацов хлора и кислорода Ао 0,5% также не оказывают губительного Аействия на микобактерии.

M.kansasii - кислотоустойчивые палочки, растущие на плотных питательных средах при температуре $37^{\circ} \mathrm{C}$. Образуют колонии R и S формы.

Впервые информация об этой группе бактерий была опубликована в 1955 году американскими учёными A.Pollak и V.B.Buhler (цит. по Ю.К. Вейсфейлеру), они называли эти бактерии yellowbacilli — «жёлтыми бацицмами» [12]. M. kansasii слабо патогенны Аля морских свинок, но вызывают поражения мегких и Аругих органов у мышей при внутривенном заражении, явАяются причиной заболеваний у Аюдей, вызывают мимфадениты подчелюстных узАов. Чаще всего прояв яется поражением дыхательной системы человека с вовлечением верхних Аолей и Аеструкцией мегочной ткани. В 1980-е годы заболевания мегких, вызванные Аанным видом микобактерий, были наиболее частыми среди НТМБ-инфекции в США. В настоящее время число заболеваний, вызванных этим возбудителем, 
значительно уменьшилось. Согласно таблице Р.T. Davidson, роль Mycobacterium kansasii в заболеваемости микобактериозом человека оценивается в 6 балмов по 10 бам ьной шкале [99].

Большинство штаммов чувствительны к рифампицину, однако могут прояв Аять устойчивость к изониазиАу, этамбутолу, стрептомицину [60].

M. marinum яв яяются условно-патогенными микобактериями, растут на плотных питательных средах при температуре $32-33^{\circ} \mathrm{C}$ в виле колоний R-, а чаще S-формы. Впервые вылелены J.D.Aronson (1926) из организма больных рыб, а Norden и Idnell (1954), L.Zettergen и B.Zetterberg (1956) - из воды купальных бассейнов и материала кожных язв человека (цит. по Ю.К. Вейсфейлеру) [12]. Патогенны Аля холоднокровных. При определенных условиях вызывают ограниченные поражения кожи рук и ног у человека.

Согласно недавнему исследованию была показана возможность спорообразования у представителей Мусоbacterium marinum [123]. ОАнако Аанная работа быма признана спорной [172].

M.scrofulaceum - кислотоустойчивые палочки. Растут на плотных питательных средах при температуре $37^{\circ} \mathrm{C}$. Колонии обычно S-формы. Впервые вылелены и изучены F.H.Prissik и F.M.Masson в 1957 году из гнойного материала при мимфаденитах (цит. по. Вейсфейлеру Ю.К.) [12]. Могут размножаться в воде и почве. Вызывают массивную экспериментальную инфекцию у мышей. При благоприятных условиях могут вызывать поражение кожи у человека и шейные Аимфадениты у детей.

Mycobacterium scrofulaceum иногда относят к группе «M. avium-complex», вкАючающую Мусоbacterium avium и Mусоbacterium intracellulare [64], оАнако исследования на молекулярном уровне показали, что скотохромогенные Mycobacterium scrofulaceum не имеют родства с обозначенными видами группы MAIS и не могут быть отнесены в оАин комплекс [123].

M.avium и M.intracellulare - кислотоустойчивые палочки. В культурах пигмента не образуют. Растут на плотных питательных средах при температуре $37^{\circ} \mathrm{C}$ с образованием колоний S-формы. Эти микобактерии имеют общие с микобактериями антигены. Как M.avium, так и M.intracellulare нередко обнаруживается в почве, причем M.avium способны Алительное время сохраняться в ней. Свойства M.intracellulare во многом совпадают со свойствами M.avium. Входят в группу видов M.avium-complex, способных вызывать МБ. ОАнако в отличие от последних M.intracellulare не патогенны Аля птиц и сельскохозяйственных животных. При попадании в организм человека могут явиться причиной заболевания. Прояв яется чаще всего поражением дыхательной системы человека с Аеструкцией легочной ткани, мимфадениты у Аетей, Аиссеминированные процессы у миц с поражением иммунной системы. За последние 10 мет повсеместно отмечается рост числа заболеваний, вызываемых M. avium-complex: в США, Японии, России и ряде стран Европы. M.aviumcomplex считается наиболее частым возбудителем заболеваний человека [60]. Согласно таблице Р. T. Davidson (1989) роль M.avium-complex в заболеваемости МБ человека оценивается в 5 балцов по 10-бальной шкале. 
Большинство культур M.avium-complex обладают естественной резистентностью к антибактериальным и часто к противотуберкулезным препаратам [60].

M.smegmatis - сапрофиты. Найдены на половых органах, особенно в смегме. Аают рост колоний через 2-3 суток после посева. Растут при температуре $37^{\circ} \mathrm{C}$.

Биохимические свойства НТМБ и, в частности, определение их энзиматической активности представляется с точки зрения некоторых исследователей перспективным Аля их классификации. Способность микобактерий разлагать сахара, содержание у них каталазы, пероксидазы, амидаз, липазы, фосфатазы и Аругих энзимов позволяет проводить идентификацию нетуберкулезных микобактерий с уже известными штаммами [89].

\section{2. УАЬТРАСТРУКТУРА ПРЕАСТАВИТЕАЕЙ НЕТУБЕРКУАЕЗНЫХ МИКОБАКТЕРИЙ}

ОАними из первых электронно-микроскопические изучения культивируемых микобактерий проводили С. Shinohara $(1957,1959)$, Т. Toda et al. (1960), А.М. Glauert и D.А. Howood (1960), М. Koike et al. (1961), А.А. Шахбанов и И.А. Гришаев (1971), R. Radanov et al., (1973). Авторы, изучавшие ультратонкое строение микобактерий, заключили, что их строение сходно со строением микобактерий Аругих видов.

Микрокапсула выявлялась на поверхности изученных клеток микобактерий. По сравнению с микрокапсулой $\mathrm{M} \Lambda$ на срезах клеток культивируемых микобактерий этот слой определялся более ясно (рис. 46, 47, 48 ,49, 50 ,51). ОчевиАно, ввиАу кучшего контрастирования культуры бактериальных клеток, нежели внутриклеточно расположенных микобактерий. В культуре клеток микобактерий микрокапсула выявлялась как по всему периметру среза микобактериальной клетки, если клетка межала обособленно, так и окружала группу клеток при тесном их соприкосновении, как бы связывая кАетки межАу собой.

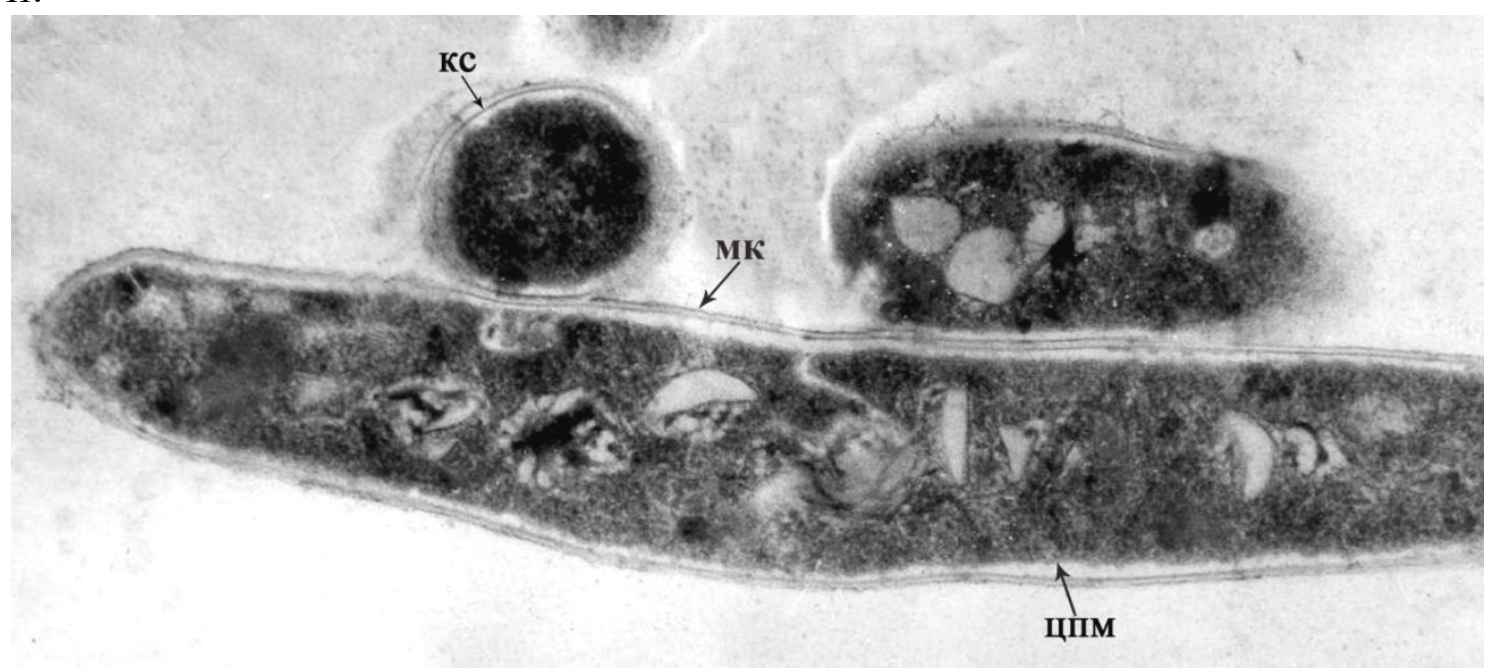

Рис. 46. УАьтраструктура Mycobacterium kansasii. $\times 20000$ 


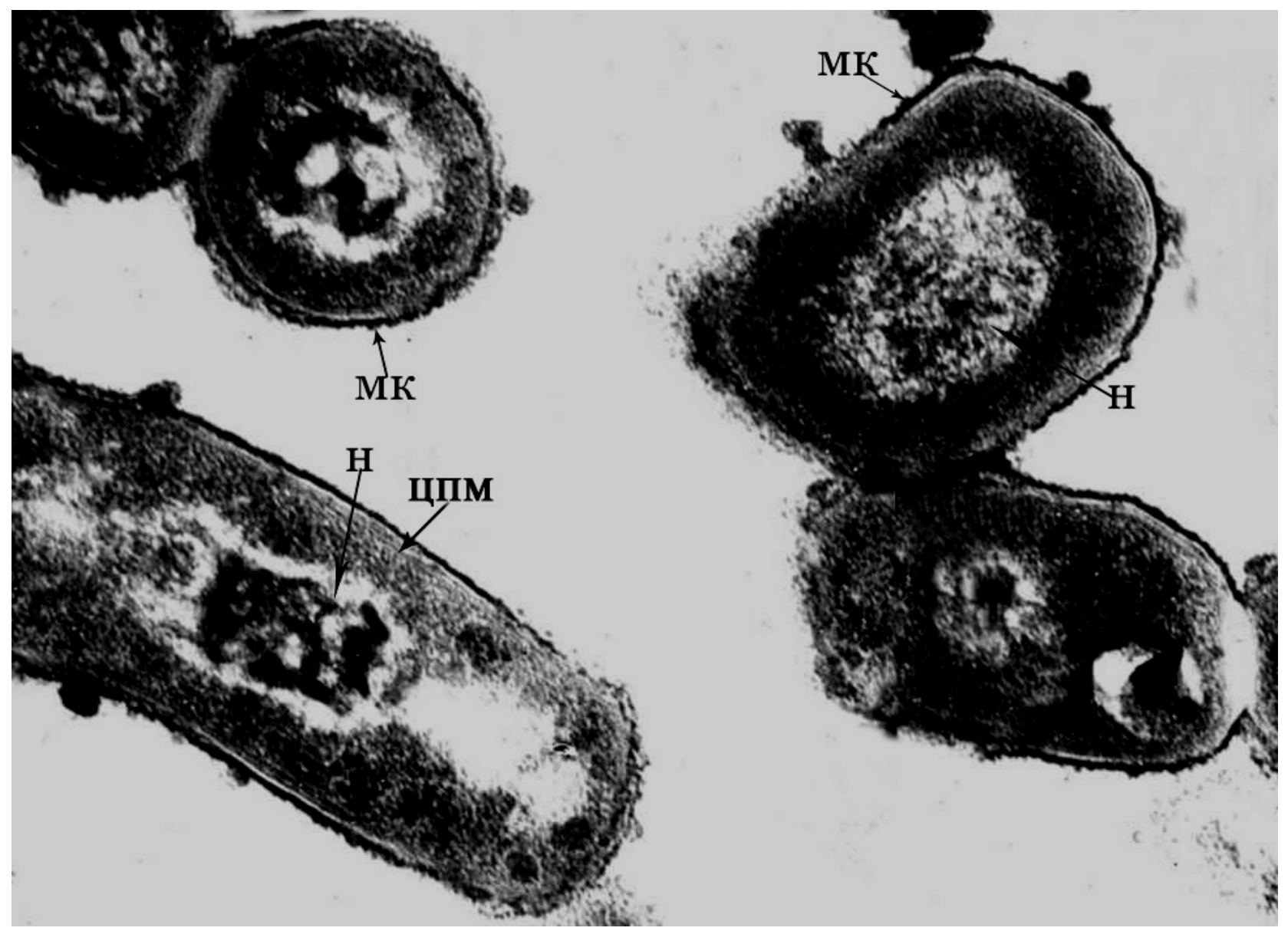

Рис. 47. УАьтраструктура Mycobacterium marinum. $× 20000$

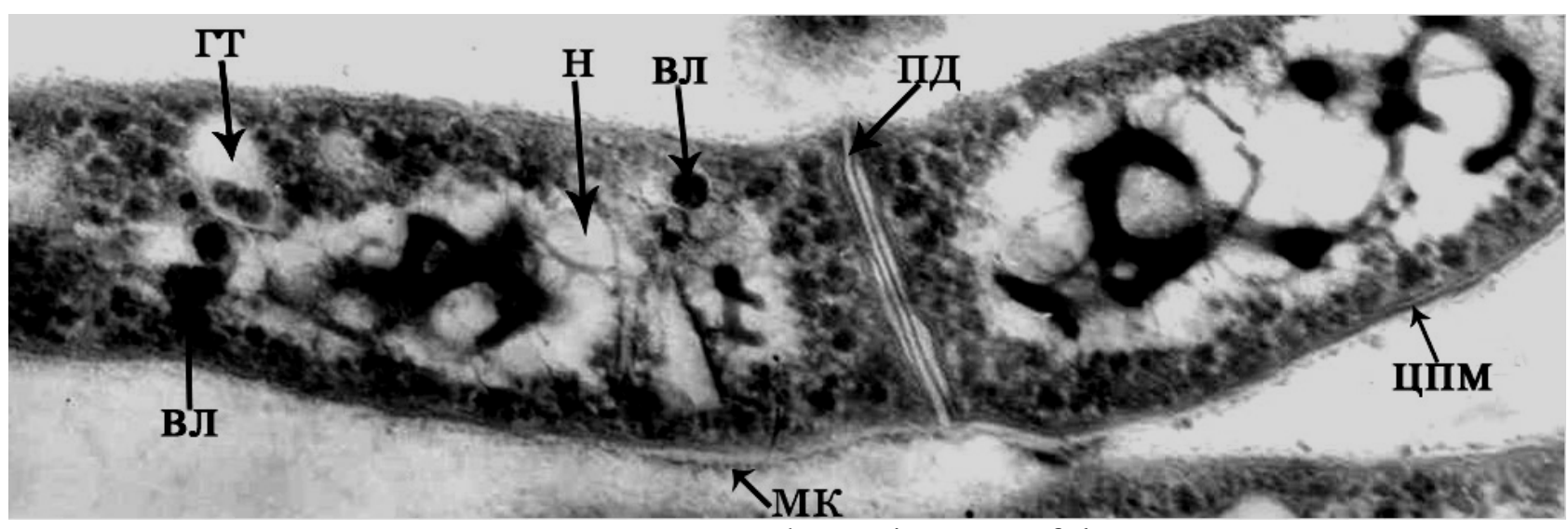

Рис. 48. УАьтраструктура Mycobacterium scrofulaceum. ×20000 


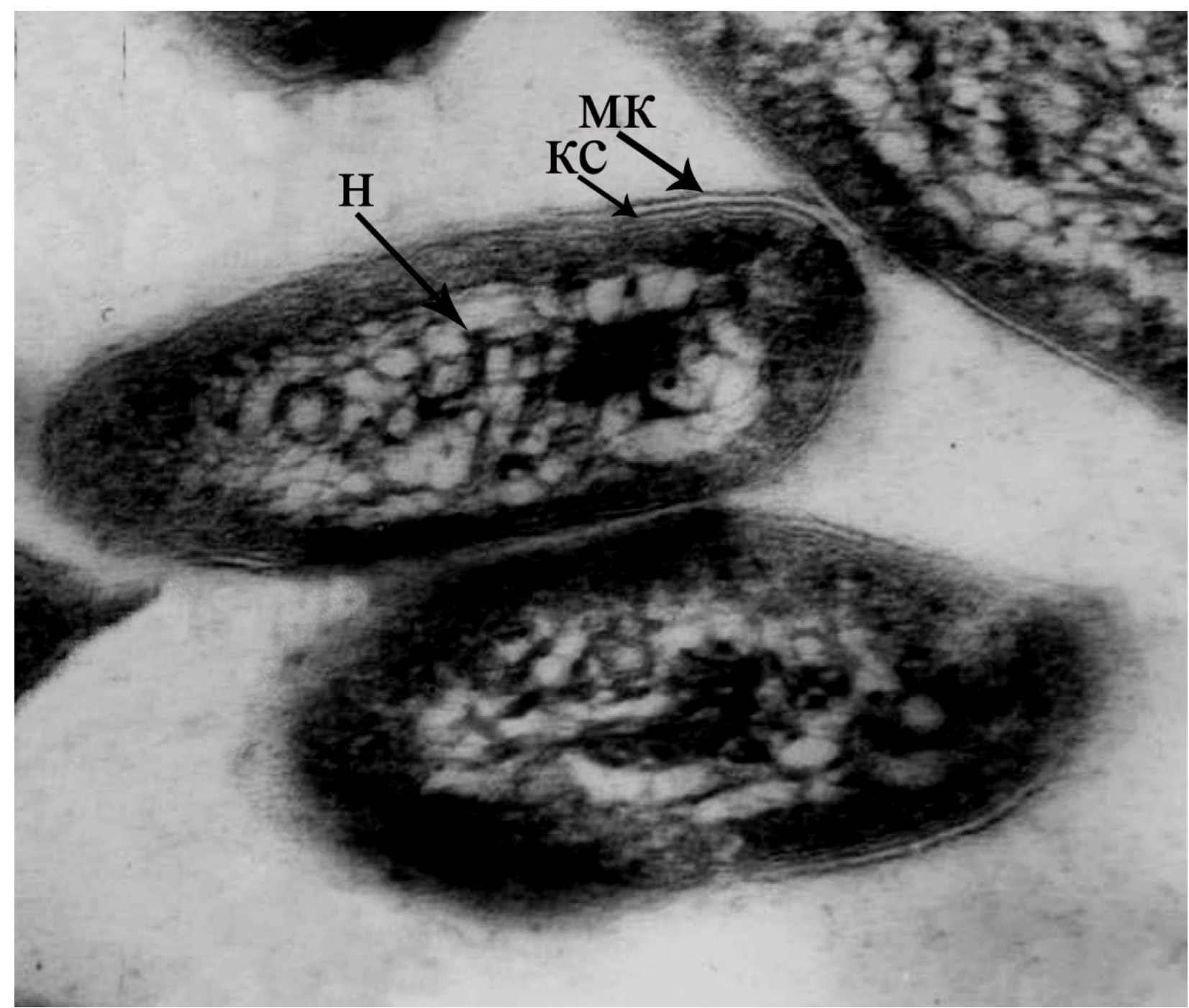

Рис. 50. У Аьтраструктура Mycobacterium intracellulare. $\times 20000$

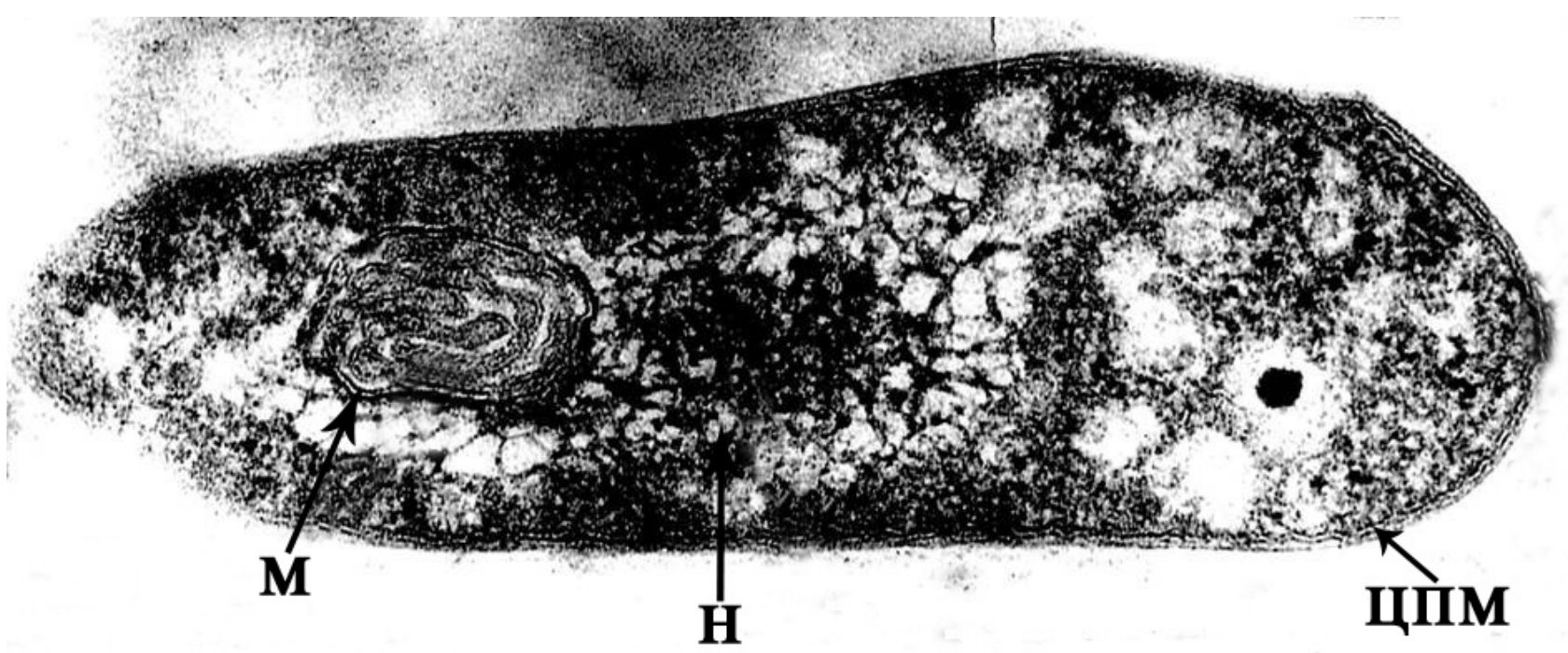

Рис. 51. УАьтраструктура Mycobacterium smegmatis. $\times 20000$ 
У всех изучаемых НТМБ обнаруживается трехслойная клеточная стенка (5-10 нм толщиной). КАетки МА имели меньшую толщину КС (3 нм). Наружный электронно-прозрачный слой клеточной стенки полностью рассеивает электроны, его присутствие особенно заметно у микобактерий, растущих на питательных средах. Электронно-плотная часть клеточной стенки выявлялась в виле одноконтурного образования у всех изученных микобактерий. Но однородным образованием данный слой не явцяется. На средах частично мизированных клеток можно проследить разделение этого слоя на Ава (рис. 52).

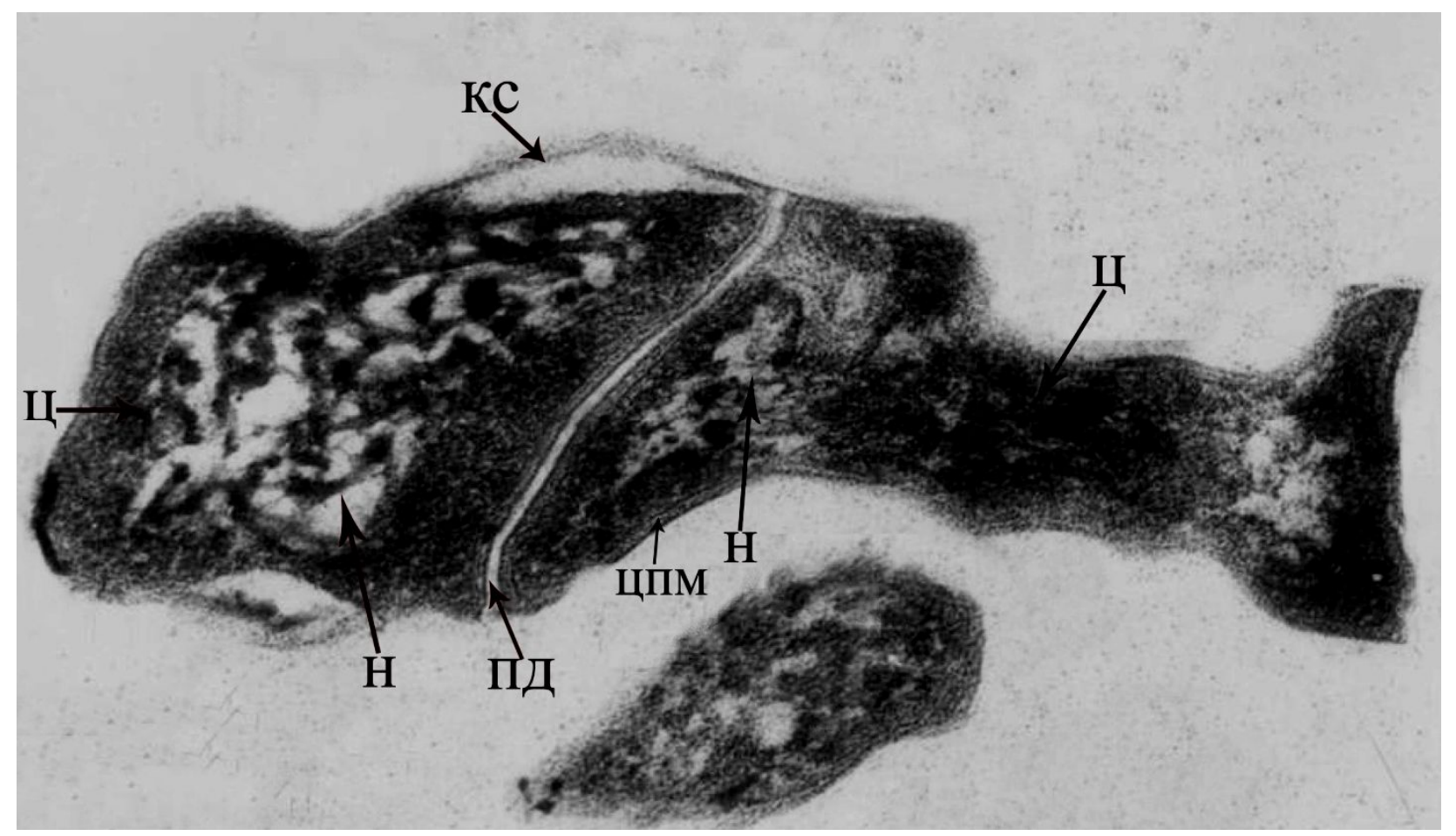

Рис. 52. Mycobacterium marinum. Расщепцение электронно-плотной части клеточной стенки на Ава электронно-плотных слоя. $\times 20000$

Обнаружены некоторые особенности, касающиеся толщины осмиофильной части клеточной стенки микобактерий. Клетки изученных микобактерий имеют большую толщину электронно-плотной части клеточной стенки (толщина 5-10 нм), чем МА (толщина 3 нм). Этот слой оболочки бактериальной клетки вместе с электронно-прозрачной частью обеспечивает форму и устойчивость микобактерий во внешней среде.

Мембранный аппарат микобактерий представлен типичной цитоплазматической мембраной и полиморфными мезосомами. Морфологическим субстратом мезосом является трехслойная мембрана, по строению и толщине (7,5-9 нм) соответствующая цитоплазматической мембране. Количество их в одном срезе микобактериальной клетки не превышало трех. Мезосомы встречались, в основном, в области формирующейся перегородки Аеления микобактериальной клетки. Нередко удавалось наблюдать связь мезосом с врастающей перегородкой (рис. 53). Обычно мезосомы Аостигали области нуклеоида и даже проникали в нее. Учитывая отсутствие ядерной мембраны, 
нельзя отрицать возможности прямого контакта мезосом с ядерным веществом. В мизированных клетках мезосомы обычно не обнаруживацись.
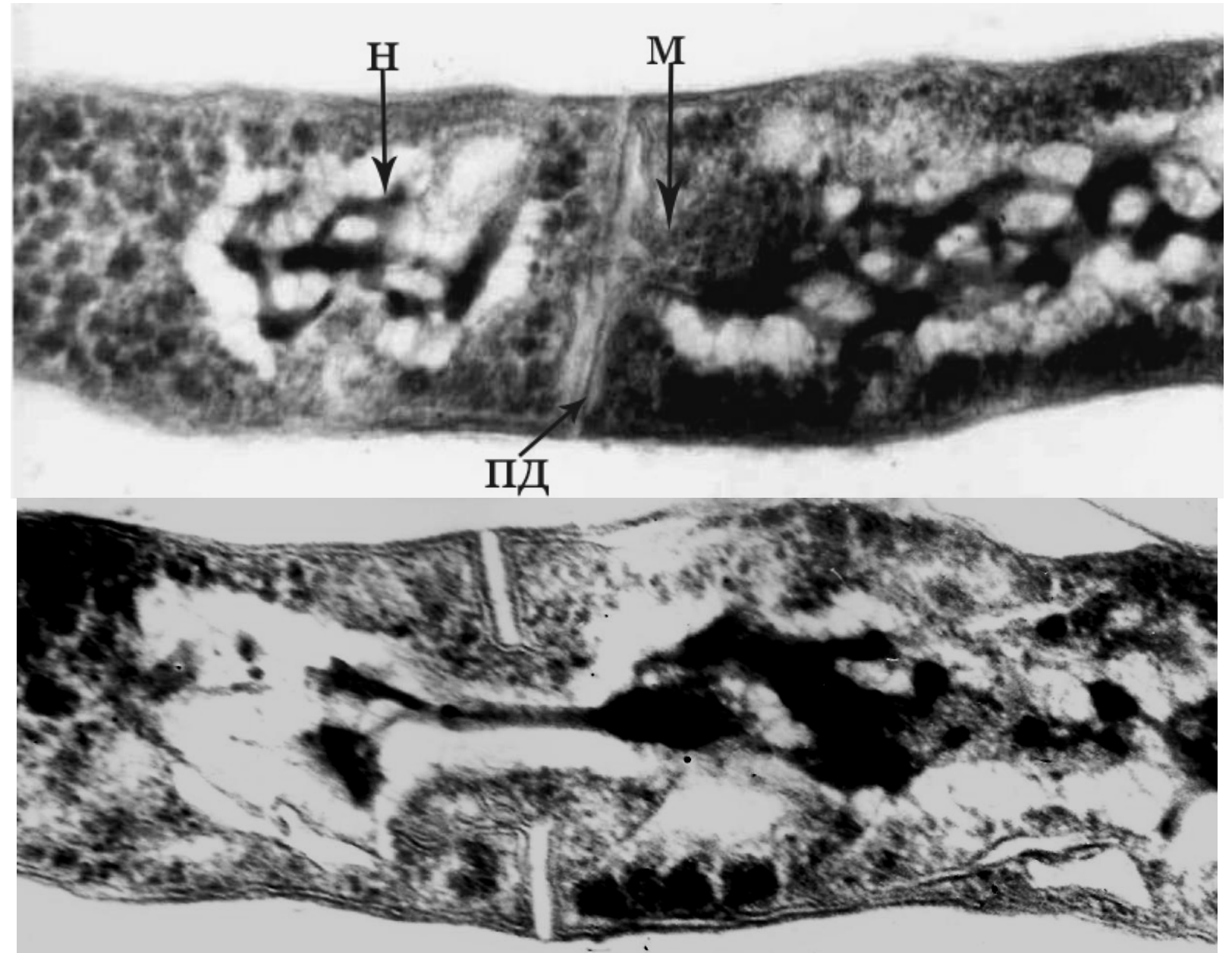

Рис. 53. Аеление Mycobacterium smegmatis. Связь мезосом с перегородкой Аеления. $\times 20000$

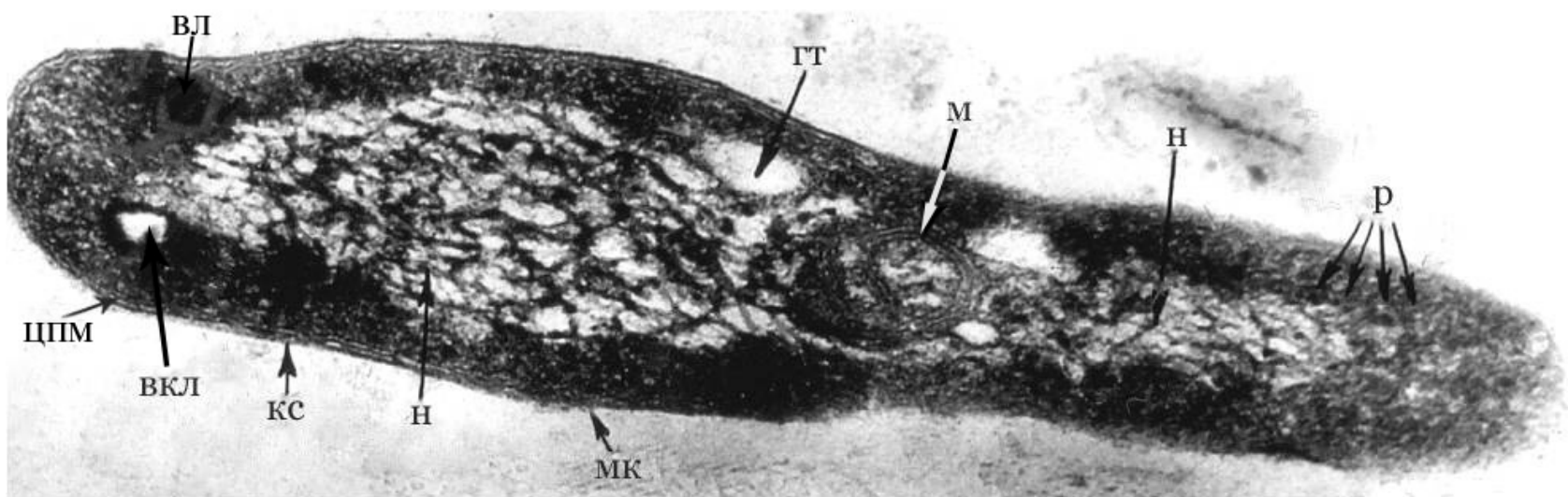

Рис. 54. Аиффузное распрелеление рибосом и полирибосом в цитоплазме M.kansasii. $\times 20000$

У культивируемых микобактерий отмечалось Аиффузное распределение рибосом и полирибосом в цитоплазме (рис. 54). Из вкАючений в цитоплазме клеток НТМБ отмечены электронно-прозрачные вакуоли, ограниченные мембраной, умеренно электронно-плотные и электронно-плотные гранулы различных размеров, розеткоподобные вкАючения. Розеткоподобные вкАючения 
обнаруживались в тех случаях, когда микобактерии культивировались на клиньях картофемя и, очевидно, представцяют собой отложения гликогена (рис. 48, 53).

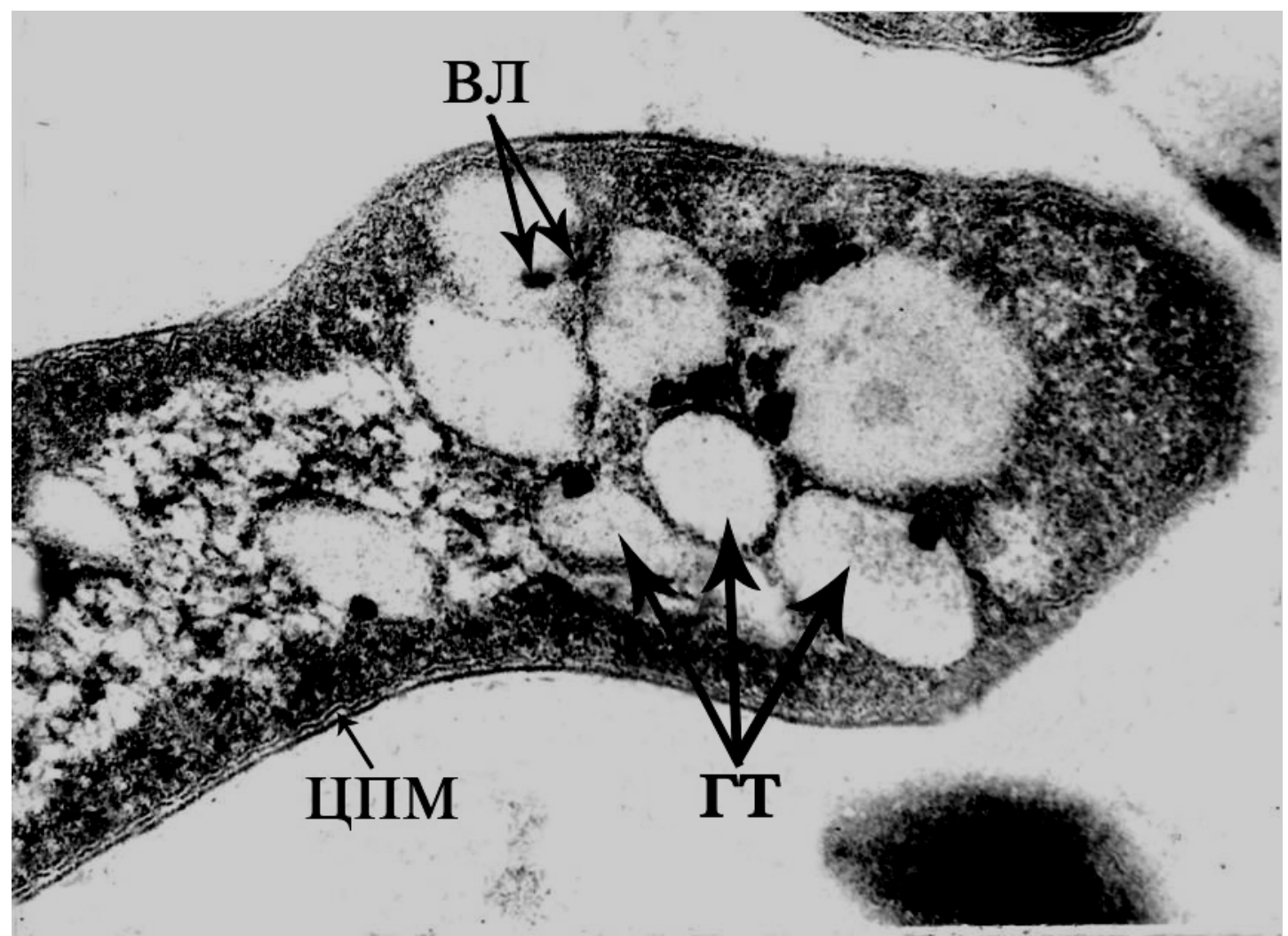

Рис. 55. Включения волютина, располагающиеся в ГТ M.intracellulare.Аеформация ядерной нити. $\times 20000$

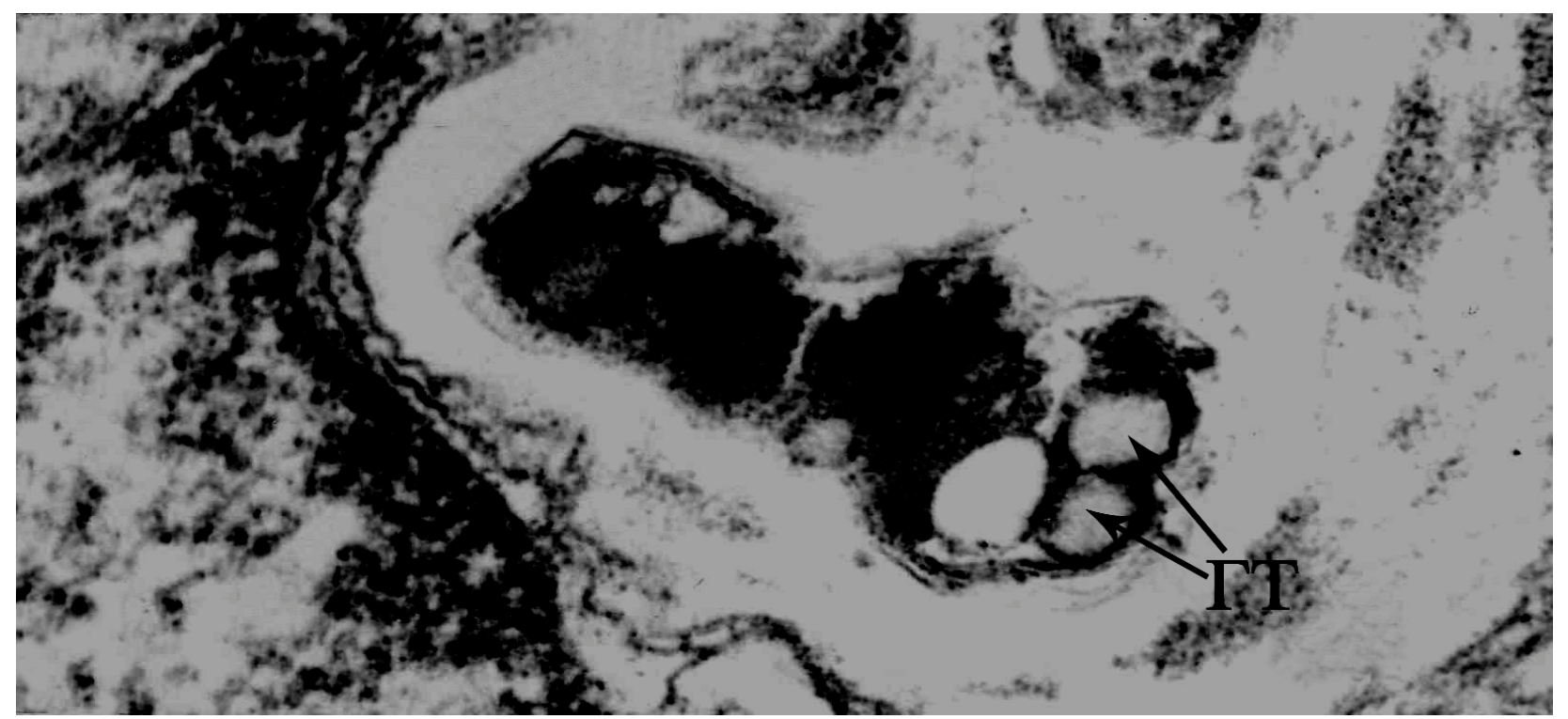

Рис. 56. ГТ в мизированных клетках Mусоbacterium marinum на фоне конденсации цитоплазмы $\times 20000$

Часто электронно-плотные гранулы располагались в «гомогенных тельцах», причем, обычно в краевой их части независимо от плотности прохождения среза (рис. 55, 56). В случае расположения «гомогенных телец» в области нуклеоила можно наблюдать, как выступающие их края деформируют ядерные нити, 
заставляя их огибать Аанные образования (рис. 55). Мезосомы микобактерий, располагаясь около «гомогенных телец», никогда не проникают в них. Особенно хорошо «гомогенные тельца» заметны в мизированных клетках на фоне конденсированной цитоплазмы (рис. 56). На основании вышесказанного можно судить о самостоятельности и большой устойчивости вкАючений к внешним возАействиям.

Кроме вышеописанных вкАючений, в клетках всех изученных микобактерий встречались электронно-прозрачные вакуоли, ограниченные трехслойной мембраной (рис 57). Эти образования представляют собой скопления мипиАов, экстрагированных из клетки в процессе препарирования материала.

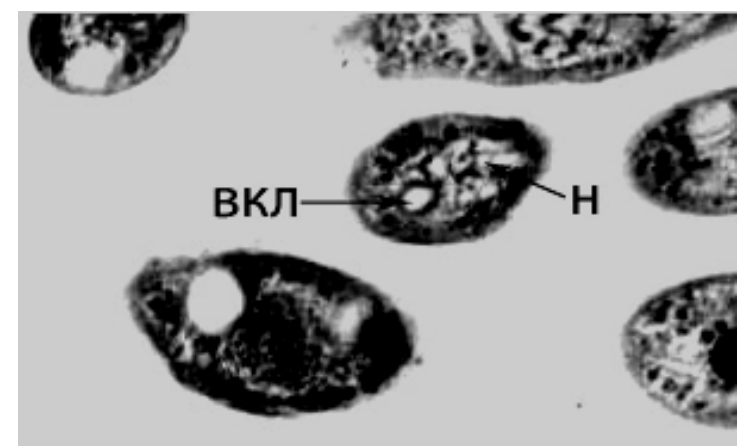

Рис. 57. Электронно-прозрачные вакуоли, ограниченные трехслойной мембраной в клетках

Mycobacterium marinum $\times 20000$

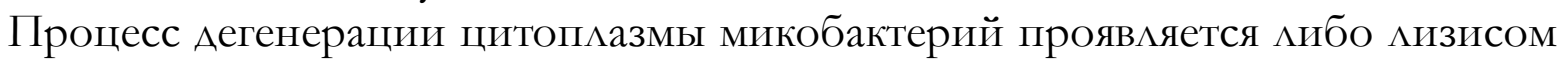
отАельных участков цитоплазмы, мибо её жировым перерожАением.

На ультратонких срезах клеток НТМБ нуклеоид четко отграничен от окружающей цитоплазмы, хотя ялерная мембрана отсутствует. Во всех случаях нами была прослежена связь нитей нуклеоила с краем его зоны посредством

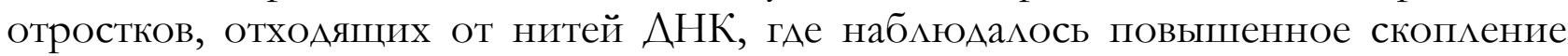
полирибосом (рис. 57, 58). Форма нуклеоида непостоянна и часто деформируется поА вОзАействием ВкАючений.

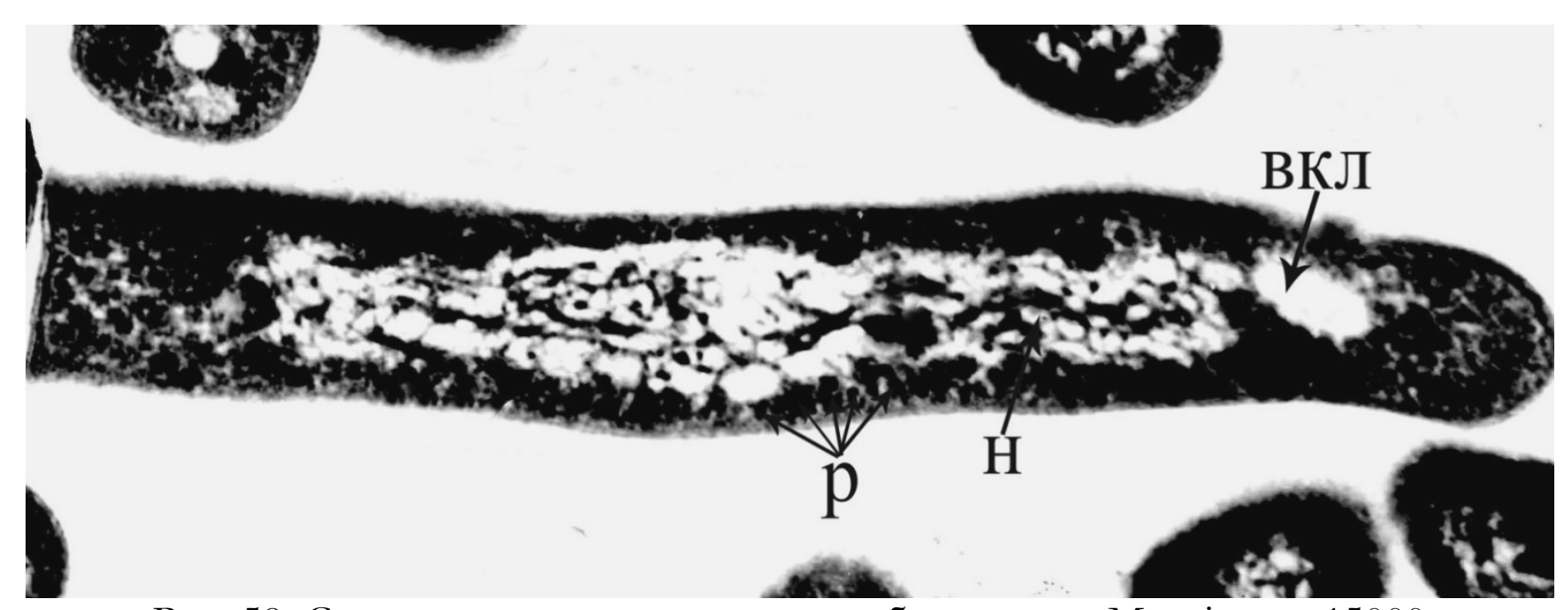

Рис. 58. Связь нити нуклеоила с полирибосомами у М. avium $\times 15000$ 


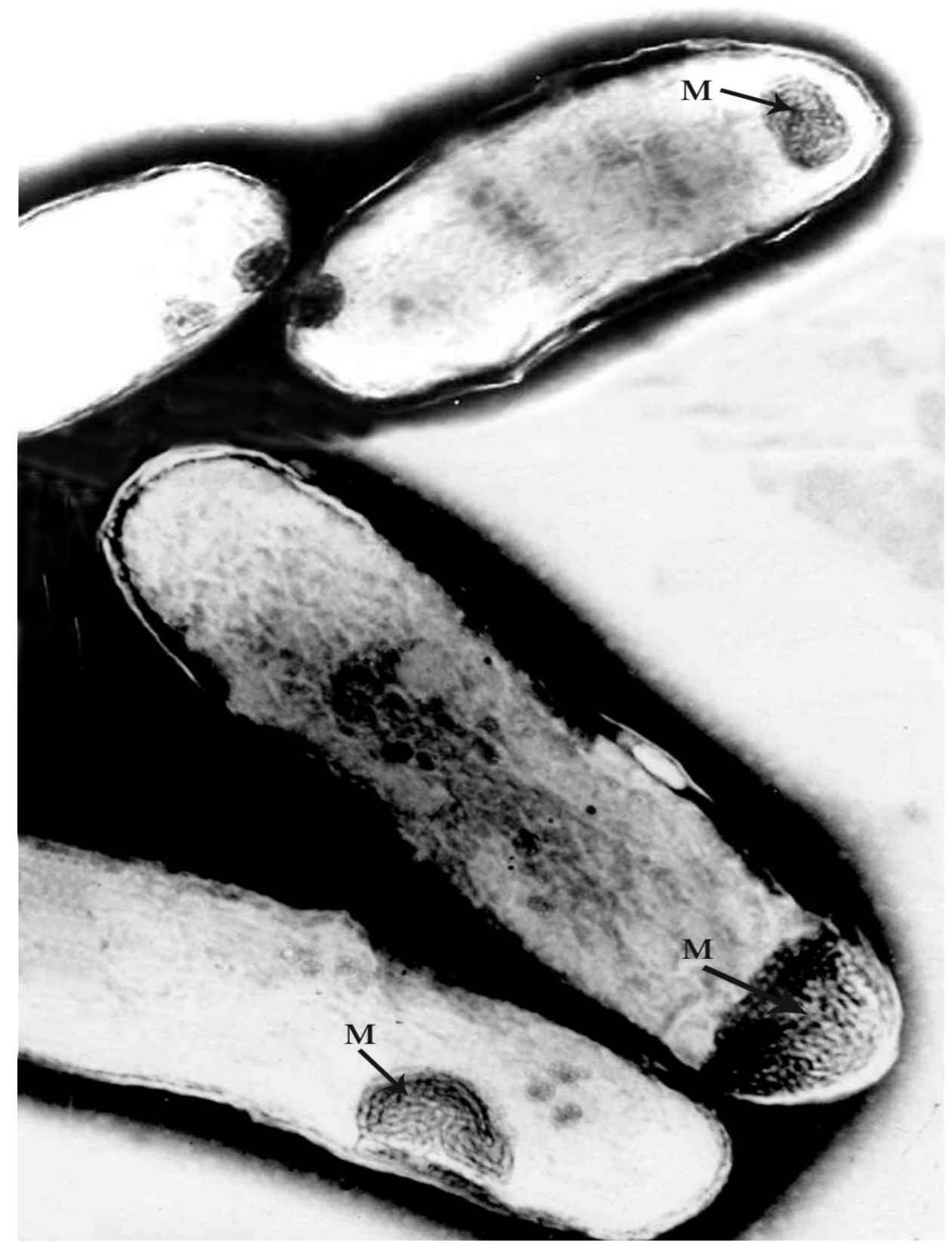

Рис. 59. Негативное контрастирование M.kansasii. $\times 20000$

Методом негативного контрастирования показано, что клетки НТМБ не имеют на своей поверхности ни выростов, ни жгутиков, ни пилей (рис. 59).

Аеление клеток НТМБ также происходит путем врастания поперечной перегородки от периферии к центру клетки. ОАнако, как показало исследование, этот способ не явцяется единственным. Нам удалось обнаружить микобактерии, процесс деления которых происходит как путем формирования перегородки, так и почкованием (рис. 60). К особенностям НТМБ некоторые авторы относят сильно развитый полиморфизм [40]. Выраженный полиморфизм отмечен у M. smegmatis (короткие, Алинные, прямые и изогнутые палочки, иногда с утолщениями), М. marinum (изогнутые палочки с утолщениями на концах) и М. avium (Алинные нитевидные кАетки Алинной Ао 8-10 мкм, прямые и изогнутые) (рис. 61). 


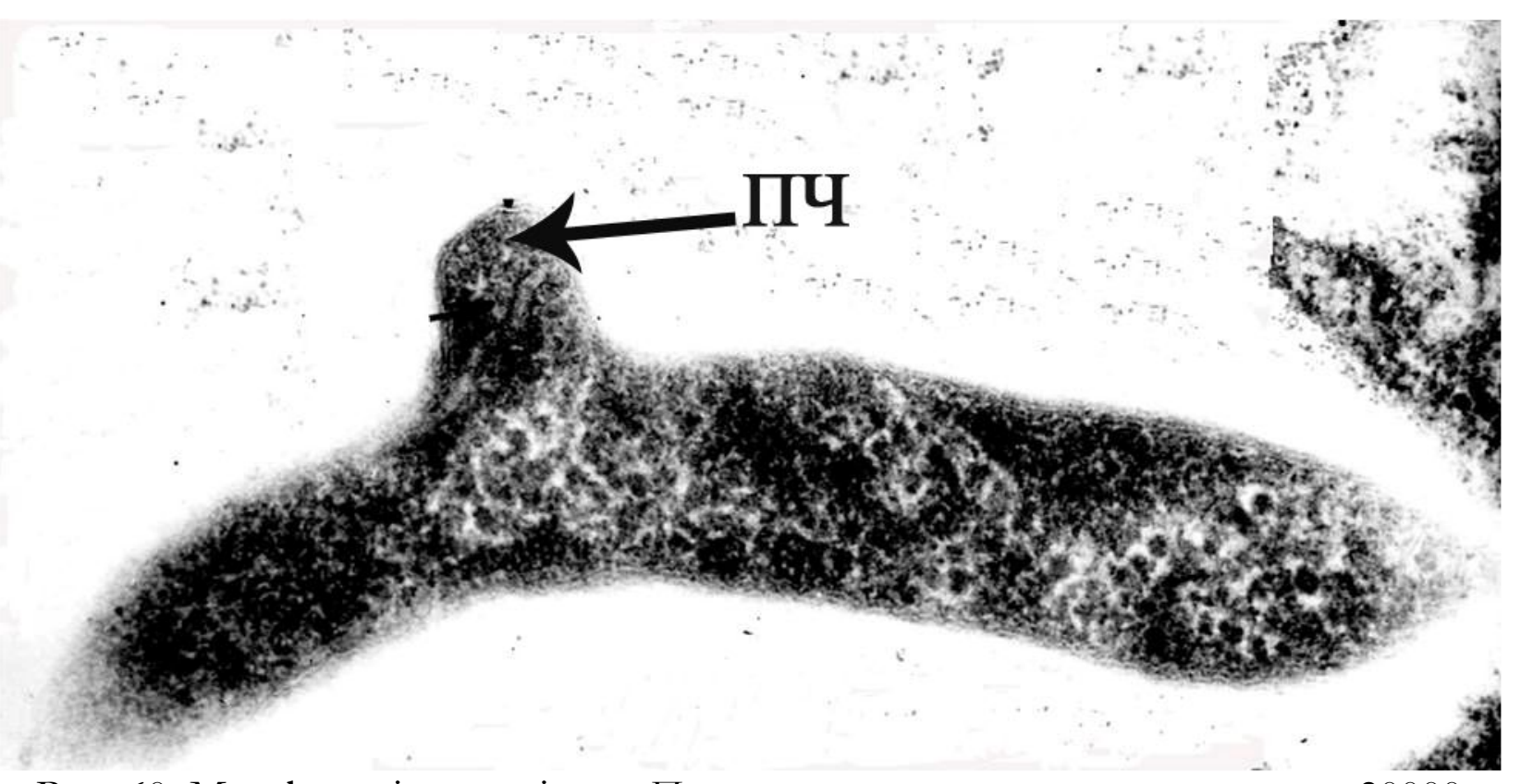

Рис. 60. Mycobacterium marinum. Процесс деления путем почкования ×20000

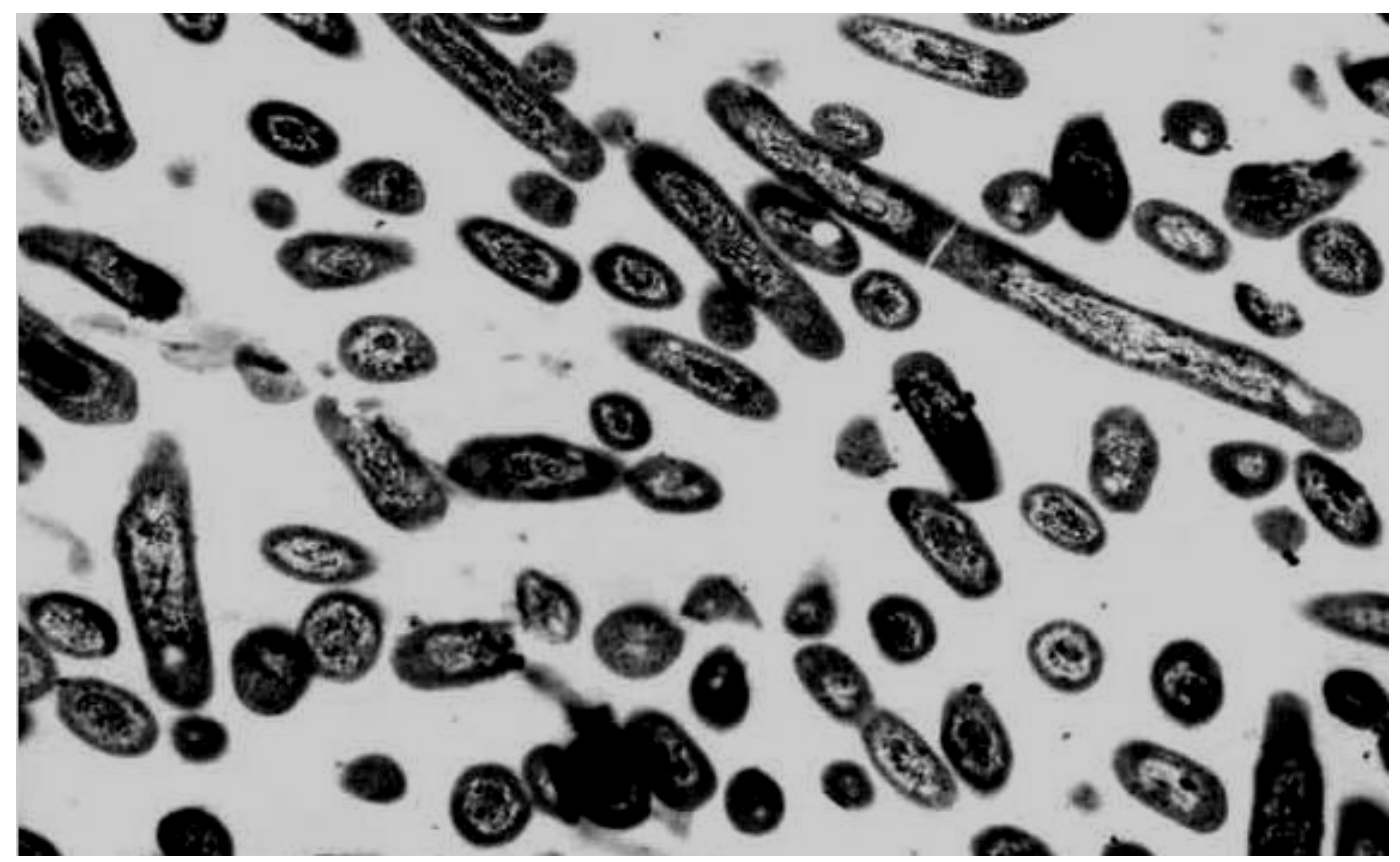

Рис. 61. Полиморфизм НТМБ ×10000 
3. ЭАЕКТРОННО-ЦИТОХИМИЧЕСКОЕ ИЗУЧЕНИЕ ПРЕАСТАВИТЕ АЕЙ НЕТУБЕРКУ АЕЗНЫХ МИКОБАКТЕРИЙ

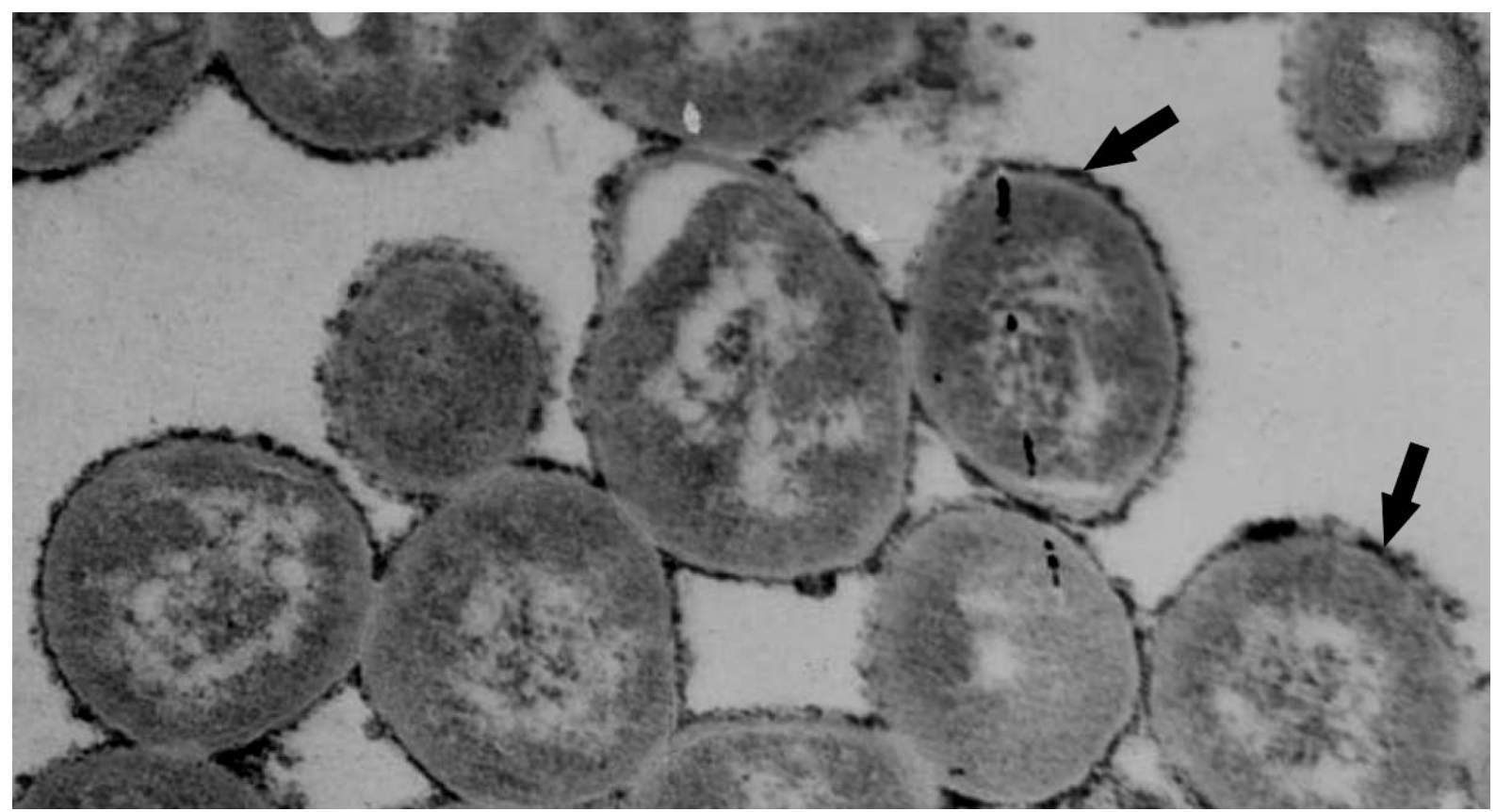

Рис. 62. Отложения рутениевого красного (стрелки), маркирующие кислые мукополисахариды в клетках M. kansasii.×20000

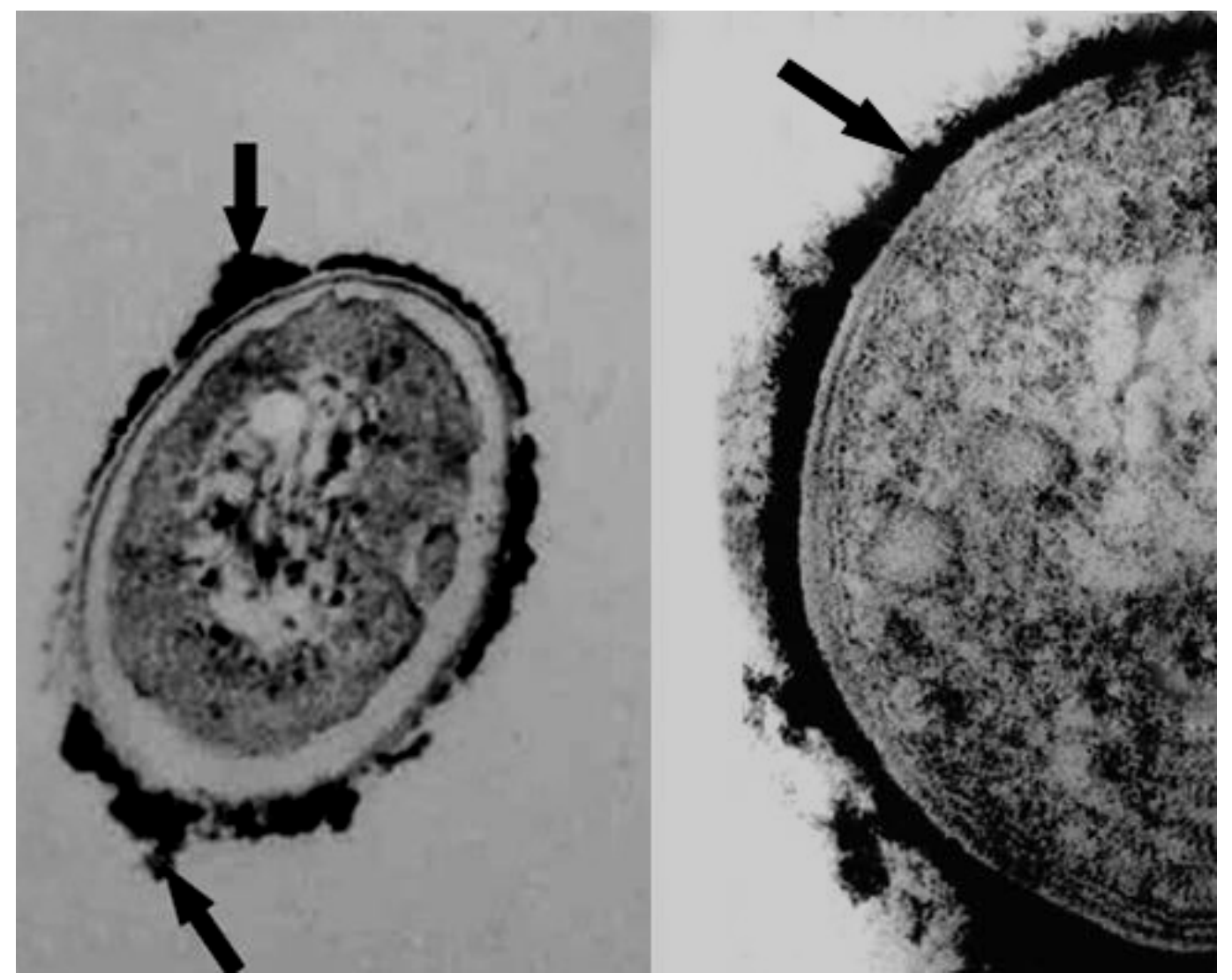

Рис. 63 Отложения рутениевого красного (стрелки), маркирующие кислые мукополисахариды в М. scrofulaceum (a), M. marinum. × 20000 
В клетках НТМБ кислые мукополисахариды маркируются отложениями рутениевого красного, выявлялись, в основном, на поверхности клеточной стенки в виле слоя неравномерной толщины, отчего наружная поверхность бактериальных клеток имела фибрилцярный виА. При малой толщине слоя в нем оказалось возможным разАичить отдельные гранулы диаметром 4-5 нм (рис. 62). Все виды рода Мусоbacterium характеризуются особой клеточной стенкой, более тонкой, гидрофобной, с наличием в ее составе восков и богатой миколовыми кислотами (миколатами) (рис. 63).

Клеточная стенка, помимо гидрофобных миколатов, в значительной степени состоит из сложных полисахаридов, некоторые из которых имеют Аля жизнедеятельности клетки особое значение. Терминальные фрагменты мипоарабиноманнана, прежле всего его маннозные раАикалы, неспецифически подавляют активацию Т-лимфоцитов и $е$ ейкоцитов периферической крови животных, что приводит к нарушению иммунного ответа на микобактерии [64]. В ходе эволюции микобактерии выработали разАичные механизмы преодоления или инактивации неблагоприятных факторов внешней среды. Во-первых, это особая клеточная стенка. Во-вторых, это обширные метаболические возможности. Они способны инактивировать многие клеточные токсины и вещества (различные перекиси, альдегиды и Аругие), разрушающие клеточную оболочку. В-третьих, это морфологическая пластичность, заключающаяся в трансформации микобактерий (образование L-форм, дормантных клеток).

Контрольные опыты с предварительной обработкой материала гиалуронидазой показали значительное снижение интенсивности отложения рутениевого красного, что предполагает основное содержание в выяв енном слое гиауроновой кислоты. В качестве контроля использовался также материал, не обработанный рутениевым красным.

У НТМБ продукт полимеризации окислительного ААБ, маркирующий места активности цитохромоксидазы, пероксидазы, НААН-диафоразы и сукцинатАегиАрогеназы, выявлялся в виде электронно-плотного вещества, располагающегося в области наружного слоя ЦПМ, а в области М во внутреннем слое, явцяющимся продолжением наружного слоя ЦПМ (рис. 64, 65, 66, 67). Интенсивность реакции на М оказалась более выраженной. Следует отметить, что интенсивность отАожений ААБ, а следовательно и активность цитохромоксиАазы, пероксидазы, НААН-диафоразы и сукцинатдегидрогеназы у НТМБ выше, чем у M.leprae (рис. 15).

Активность АОФА-оксидазы у НТМБ отсутствоваца. 


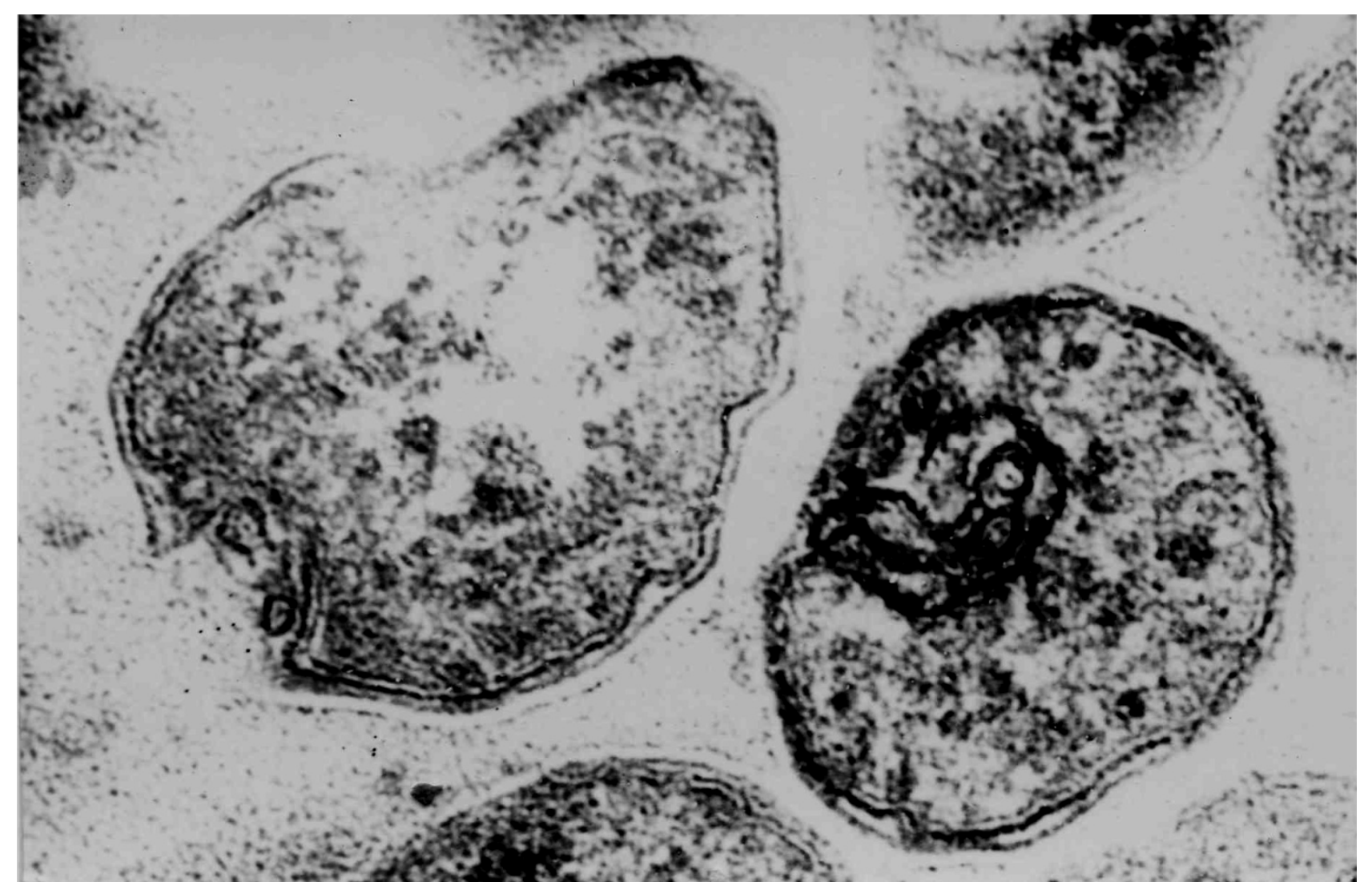

Рис 64. Отложения ААБ (стрелки), маркирующие места активности цитохромоксидазы в клетках M.marinum. $\times 20000$

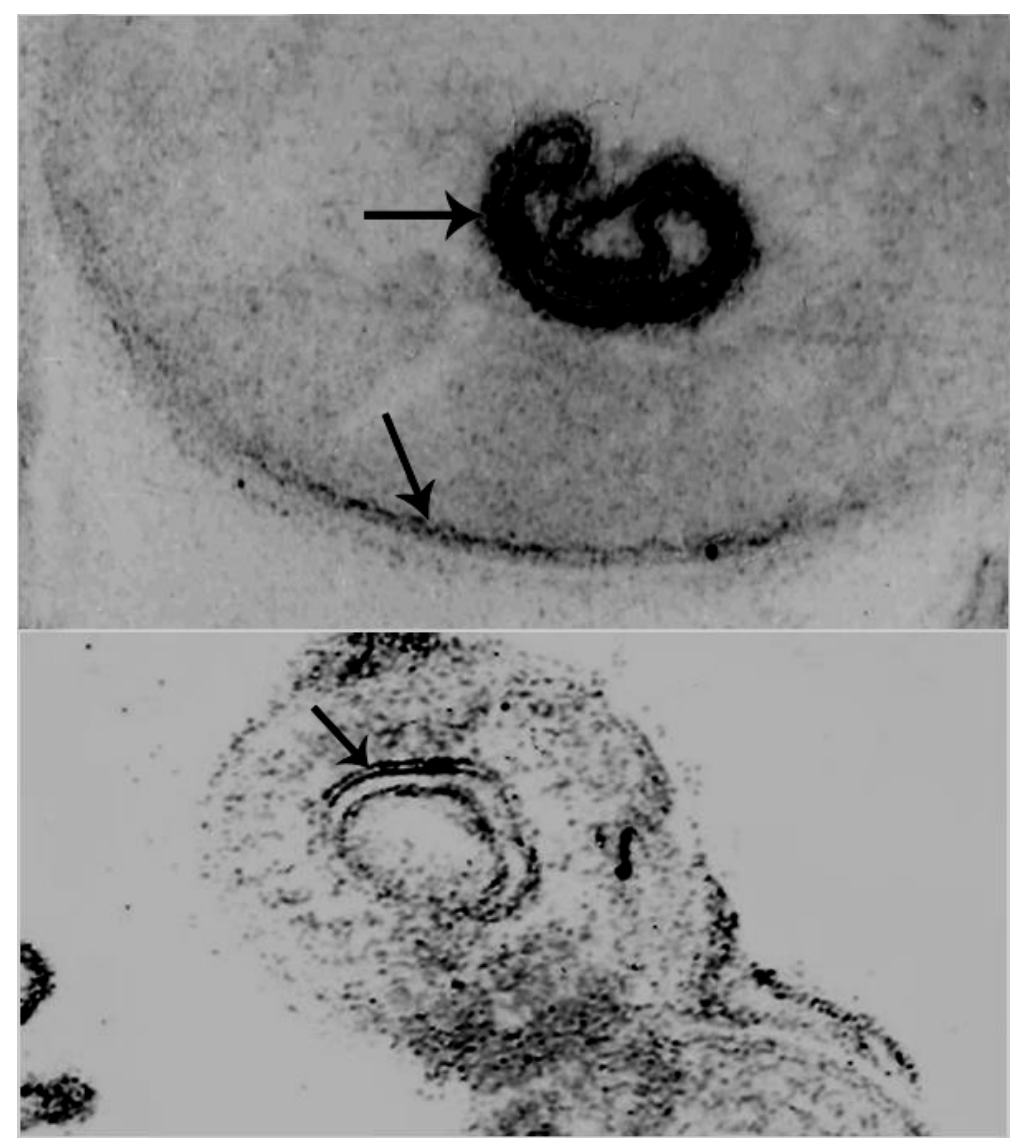

Рис 65. Отложения ААБ (стрелки), маркирующие места активности пероксидазы в клетках M.smegmatis. $\times 20000$ 


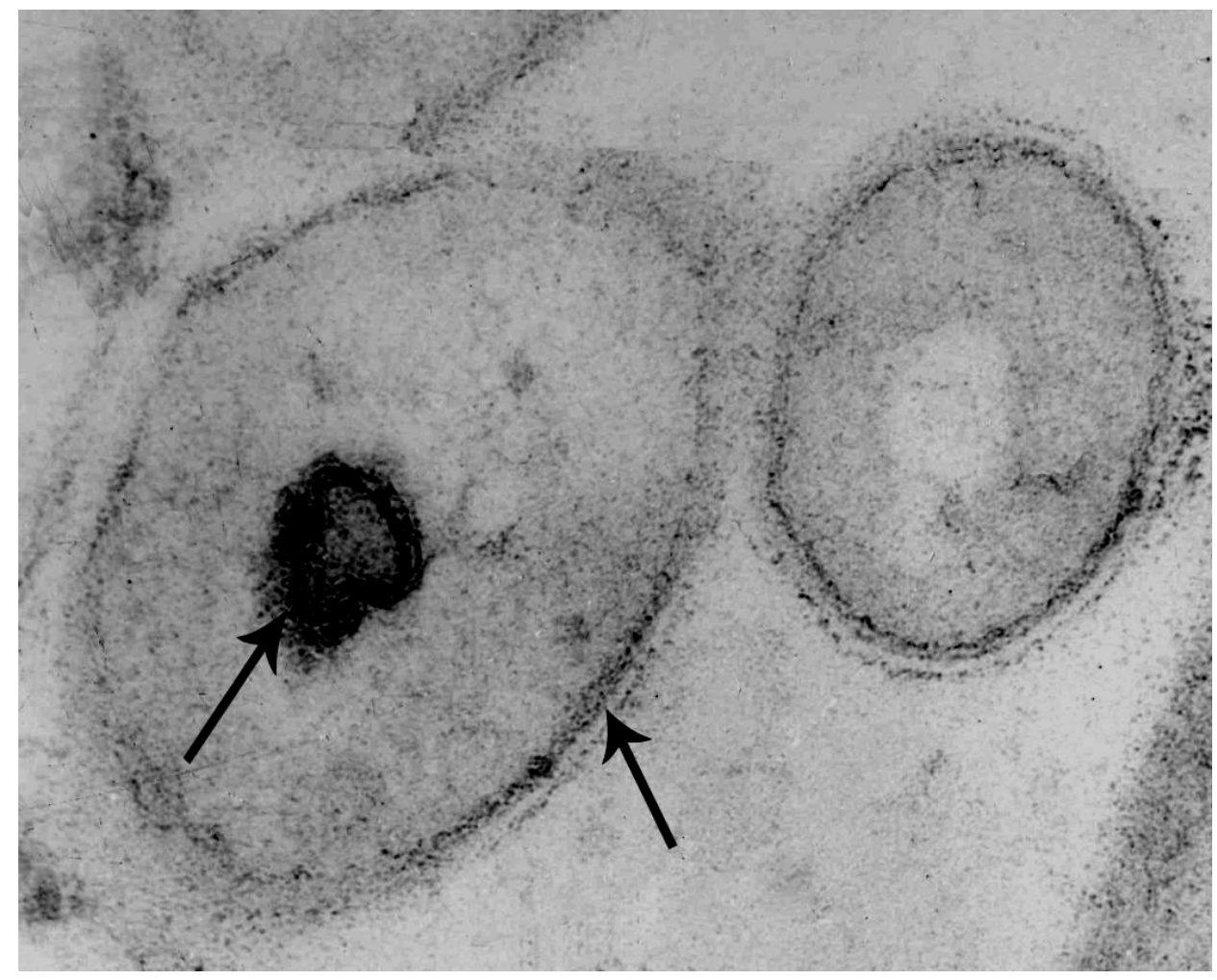

Рис 66. Отложения ААБ (стрелки), маркирующие места активности сукцинатдегидрогеназы в клетках M. avium $\times 20000$

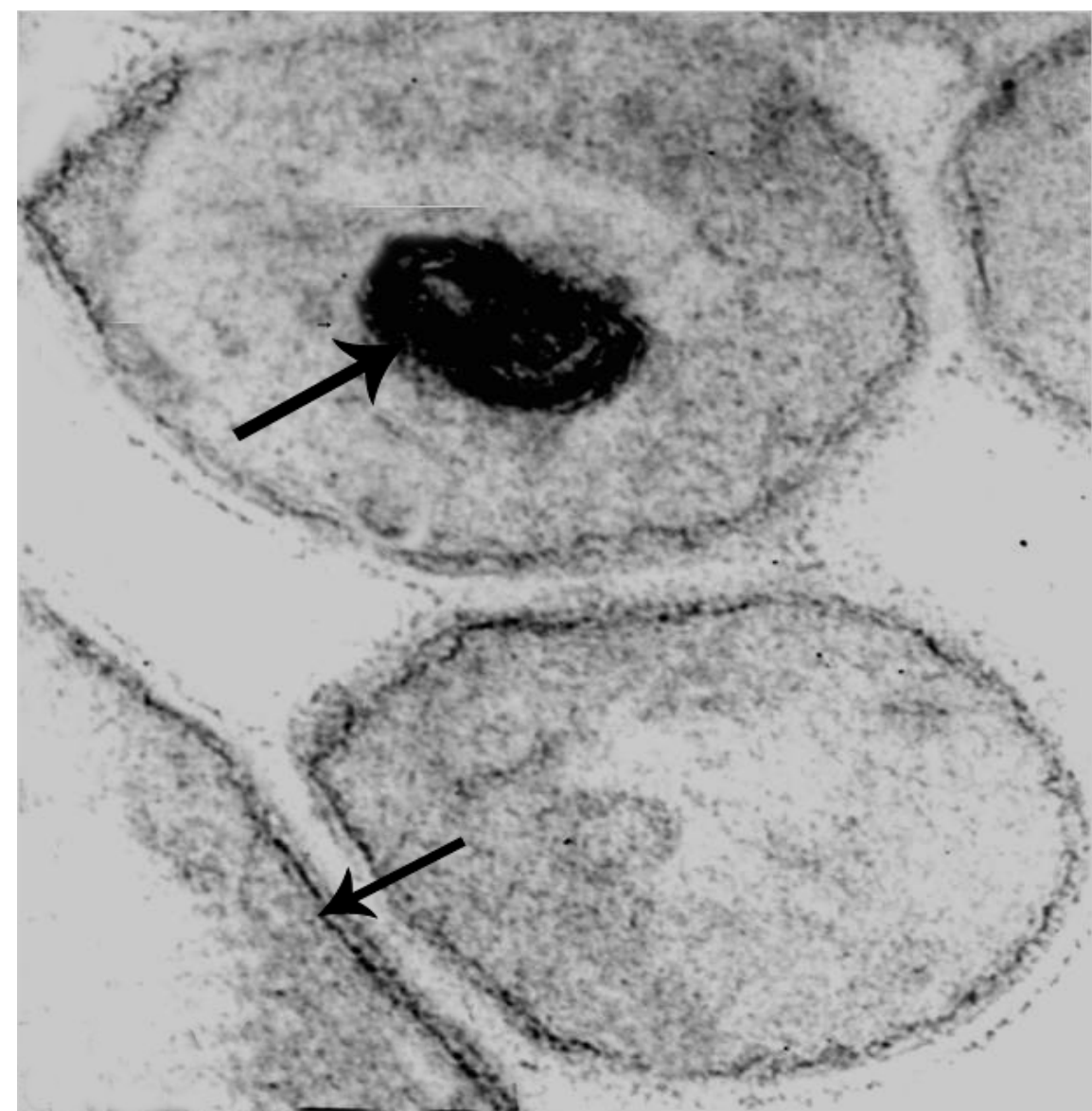

Рис 67. Отложения ААБ (стрелки), маркирующие места активности НААН-диафоразы в клетках М. avium $\times 20000$ 


\section{ЗАКАЮЧЕНИЕ}

Полученные Аанные о суб̆микроскопической организации микобактерий мепры и туберкулеза и сходных с ними по строению культивируемых микобактерий позволили описать строение и химический состав микобактерий и показали единый принцип их организации. На ультратонких срезах показано наличие микрокапсулы, клеточной стенки и трехслойной цитоплазматической мембраны. Микрокапсула $\mathrm{M} \Lambda$ яв яется фактором, препятствующим их внутриклеточному перевариванию. Наличие сложно устроенных поверхностных структур микобактерий позволяет им существовать в пределах различных температур и приспосабливаться к окружающим их условиям.

Сама цитоплазма имеет зернистое строение, содержит нуклеоил, не

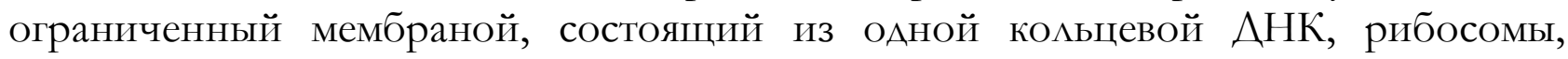
электронно-прозрачные вакуоли, ограниченные трехслойной мембраной, электронно-плотные гранулы, представляющие собой вкАючения волютина и «гомогенные тельца» - гранулы с умеренной электронной плотностью, обладающие высокой устойчивостью к внешним воздействиям. ПреАставлено разнообразное строение мезосом. Каждое из перечисленных структурных образований имеет еще более сложное строение, частично представленное в атласе.

С помощью электронной микроскопии показано размножение микобактерий не только способом поперечного Аеления, но и представлены способы демения перетяжкой и почкованием. Наличие спороподобных образований, фильтрующихся форм микобактерий, покоящихся форм объясняет изменение клинической картины заболеваний при этих формах, свилетельствует о понижении патогенности и изменении антигенных свойств, повышении устойчивости к мекарственным препаратам, что заставляет пересмотреть ряА вопросов патогенеза цепры, туберкулеза и микобактериозов.

В настоящем исследовании мы применили методы электронной микроскопии и эмектронной цитохимии в сочетании с гистохимическими и иммунологическими методами, основная задача которых заключается в познании, изучении не только Аеталей строения возбудителей, но и функции выявленных структурных образований. Все это позволило провести изучение надмолекулярной структуры микроорганизмов, а также функциональной организации структурных компонентов микобактериальных клеток, расположенных непосредственно в клетках организма-хозяина.

Сравнительное изучение микобактерий обнаружило ряА разАичий у $\mathrm{M} \Lambda$, МТ и НТМБ. Из особенностей строения отмечена более тонкая клеточная стенка у МА. Изучены активность и Аокализация в мембранных структурах (мезосомах и цитоплазматической мембране) микобактерий важных окислительновосстановительных ферментов (сукцинатдегидрогеназы, НААН-Аиафоразы, цитохромоксидазы и пероксиАазы), что позволяет судить о существовании у них собственных ферментных систем. Полученные данные о цокализации и активности ферментов характеризуют микобактерии как аэробы, способные к 
росту in vitro. Установцено, что активность цитохромоксидазы и пероксидазы у микобактерий мепры снижена по сравнению с активностью тех же ферментов у культивируемых микобактерий, что коррелирует с показатемями их биологической активности.

В результате исследования материала от больных мепрой в различных стадиях заболевания и на фоне мечения обнаружены факторы, обеспечивающие Аепонирование инфекции в организме больного. Продемонстрирован процесс

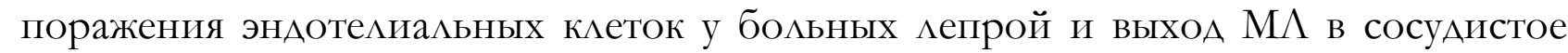
русло. Аеструктивное изменение сосудов у больных в активной стаАии болезни позволяет рекомендовать проведение неспецифического мечения, направленного на усиление репаративных процессов в поврежленных сосудах.

Этой книгой хотелось бы показать, что данные, полученные при изучении микобактерий, могут быть использованы Аля решения многих теоретических и практических проблем, волнующих как биологов, так и практикующих врачей. Так как изучение разАичных звеньев морфологической структуры микобактерий возбудителей инфекционных заболеваний, предлогает найти новые подходы в борьбе с ними.

Все вышеизложенное указывает на большую значимость полученных электронно-микроскопических данных и необходимость продолжения научных исследований в этом направлении. Полученные результаты - только начало Аальнейших исследований в области изучения возбудителей мепры, туберкулеза и микобактериозов, которые, несомненно, помогут успешной борьбе с ними. 


\section{АИТЕРАТУРА}

1. А.С. 1636717 (СССР) Способ прогнозирования рецидива Аепрозного процесса / А.К. Маслов, А.А. Ющенко // Открытия. Изобретения. - 1991. - № 11. - C.122-122.

2. Авакян, А.А. Атлас анатомии бактерий, патогенных Аля человека и животных / А.А. Авакян, А.Н. Кац, И.Б.Павцова. - М.: Медицина, 1972. - 183 с.

3. БаАовская, 3.В. Попытка экспериментального заражения морских свинок и белых мышей мепрой человека /3.В. Бадовская, В.Н. Погорелов, А.М. Чернышева / / Учен. зап. Ин-та по изучению кепры. - Астрахань, 1970. №6 (11). - C. 332-337.

4. Бадовская, 3.В. ВАияние ультразвуковых волн на интенсивность роста Mycobacterium leprae в жилких питательных средах /3.В. Бадовская, А.К. Маслов // Журн. микробиол. - 1984. - №3. - С. 26-29.

5. Бадовская, 3.В. Попытка культивирования возбудителя мепры в жидких питательных средах при Аобавлении в них детергентов / 3.В. Бадовская, А.К. Маслов // Эпидемиология, клиника, диагностика и профилактика антропонозных и зоонозных инфекций: материалы конф. - Астрахань, 1982. C. 227-228.

6. Бала, М.А. Иммунные комплексы в патогенезе бактериальных инфекций / М.А.Бала, // Врач. дело. - 1990. - №2. - С. 5-10.

7. Баранников, И.А. Бактериология проказы / И.А. Баранников // Рус. журн. кожн. и венер. болезней. - 1903. - № 3. - С. 433-435.

8. Барков, А.М. Селекция и генетика возбудителей особо опасных инфекций / А.М. Барков, М.К. Петерс. - Саратов, 1982. - 84 с.

9. Борисов, $\Lambda$. Б. Медицинская микробиология, вирусология и иммунология / А. Б. Борисов. - М.: МИА, 2005. - 454 с.

10. Бреннан, П.Аж. УАьтраструктура микобактерий туберкулеза /П.Аж. Бреннан, Ф. Арепер // Туберкулез, патогенез, защита, контроль /поА. реА. Б.Р. БАума; пер. А.С.Анта [и Ар.]. /под. ред. М.А. Карагунского. - М.: Медицина, 2002. ГА. 19. - С. 294-306.

11. Васюренко, 3.П. Состав жирных кислот бруцелм различных видов и его связь со средой выращивания / 3.П. Васюренко, К.М.Синяк, А.С.Коротич, А.А.Антонова // Журн. микробиол. - 1977. - №8. - С. 53-59.

12. Вейсфейлер, Ю.К. Биология и изменчивость микобактерий туберкулеза и атипичные микобактерии / Ю.К. Вейсфейлер. - Будапешт.: ИзА-во академии наук Венгрии, 1975. - 335 с.

13. Вишневецкий, Ф.Е. Интерпретация Аанных цитохимического исследования мепрозной клетки в свете современных представ ений о макрофаге / Ф.Е. Вишневецкий // Учен. зап. Ин-та по изучению мепры. - Астрахань, 1976. - № 9 (14). - С. 155-162.

14. Вишневецкий, Ф.Е. Патоморфологические изменения внутренних органов интактных и зараженных микобактериями мепры девятипоясных броненосцев / Ф.Е. Вишневецкий, А.А. Ющенко // Бюл. эксперим. биол. и медицины. 1981. - №8. - C. 105-109. 
15. Вишневецкий, Ф.Е. Энзимный спектр и ультраструктура мепрозного макрофага при экспериментальной мепре броненосцев / Ф.Е. Вишневецкий, А.А. Ющенко // Фагоцитоз и иммунитет. - М., 1983. - С. 54-54.

16. Воробьев, А. А. Атлас по меАицинской микробиологии, вирусологии и иммунологии /А. А. Воробьев. - М.: МИА, 2003. -375 с.

17. Гайер, Г. Электронная гистохимия / Г. Гайер. - М.: ИзА-во «Мир», 1974. - 488c.

18. Гюберт, И.И. О культуре мепрозного бацимла / И.И. Гюберт // Протоколы засед. Кавказского меА. об-ва. - 1903. - № 6. - С. 138-139.

19. Арабик, Р. Некоторые Аанные о современной ситуации мепры в мире / Р. Арабик // Материалы междунар. науч.-практ. конф., посвящ. 60-летию института и 85-летию противолепрозной службы России (16-17 октября 2008 г., Астрахань): сб. науч. ст. - Астрахань: ИзА. Аом «Астраханский университет», 2008. - C. 27-28.

20. Арабкина, Р.О. Микробиология туберкулеза / Р.О. Арабкина. - М.: МеАгиз, 1963. - 255 c.

21. Ауйко, В.В. Эпидемиология и организация борьбы с мепрой в России в современных условиях / В.В. Ауйко // Актуальные вопросы кАинической и экспериментальной мепрологии. Материалы междунар. науч.-практ. конф., (22-24 сентября 2011 г., Астрахань). - Астрахань: ИзА. Аом «Астраханский университет», 2011. - С. 6-16.

22. Аячина, М.Н. ИАентификация антигенных детерминант Муcobacterium leprae, пассируемых на лабораторных животных с помощью моноклональных антител / М.Н. Аячина, А.А. Ющенко, Ч.А-оглы Ибрагимов и Ар. // Журн. микробиол. - 1994. - №1. - С. 74-76.

23. Ермакова, Н.И. К вопросу о морфологической изменчивости возбудителя мепры / Н.И. Ермакова // Сб. науч. работ по мепрологии и дерматологии. Ростов-на-Аону, 1956. - №7. - С. 156-179.

24. Ерохин, В.В. УАьтраструктура вирулентных туберкулезных микобактерий / В.В. Ерохин, 3.С. Земскова, И.Р. Аорожкова, Н. ВиАин //Микробиология. 1972. - №11. - C. 80-84.

25. Ерохин, В.В. ЭАектронно-микроскопическое изучение микобактерий туберкулеза /В.В. Ерохин, В.Ф. Салов, С.В. Мкртчян, И.А. Панасек //Пробл. туберкулеза. - 1971. - №2. - С. 75-80.

26. Журавлева, Г.Ф. Об активности основных ферментов цикла Кребса в коже больных мепроматозной проказой (гистохимическое исследование) // Учен. зап. Ин-та по изучению мепры. - Астрахань, 1970. - № 6 (11). - С. 361-367.

27. Журавлева, Г.Ф. Патоморфология и патогенез поражений кожи при мепре: автореф. Аис. ... А-ра меА. наук : защищена 12.04.1997 г. утв. 24.09.1997. / Г.Ф. Журавлева. - М.: ВАСХНИА , 1997. - 40 с.

28. Иртуганова, О.А. Современные возможности микобактериологической маборатории / О.А. Иртуганова // Клин. маб. Аиагностика. - 2006. - №1. C. 21-35.

29. Йоргенсен, Аж.Х. Микробиологический справочник Аля клиницистов / Аж.Х. Йоргенсен, М.А. Пфалцер; пер. с англ. - М. : Мир, 2006. - 243 с. 
30. Каграманов, А.И. Использование электронного микроскопа Аля изучения возбудителя туберкулеза /А.И. Каграманов // 5 Всесоюз. съезА врачей фтизиатров: труды. - М.: Медгиз, 1950. - С. 340-341.

31. Каграманов, А.И. Возбудитель туберкулеза /А.И. Каграманов // Туберкулез. М.: Медгиз, 1955. - С. 34-40.

32. Кац, $\Lambda . Н$. Субмикроскопическая организация микобактерий туберкулеза / А.Н. Кац, С.А. Гулевская, А.П. Зубок, М.Н. Немсацзе // Журн. микробиол. 1972. - №4. - C. 33-37.

33. Кац, $\Lambda . Н$. Субмикроскопическая структура клеточной стенки бактерий (обзор митературы) / А.Н. Кац // Журн. микробиол. - 1973.- №4. -С. 105-113.

34. КеАровский, В.И. Опыт прививки проказы кролику / В.И. КеАровский // Практ. врач. - 1902. - № 17. - С. 370-371.

35. Кедровский, В.И. Изменчивость в группе актиномицетов в связи с учением о грибковой природе туберкулезного и мепрозного вирусов / В.И. КеАровский // Арх. пат., анат. и пат. физиол. - 1935. - Т. 1, № 5-6. - С. 18-36.

36. КАитин, И.И. Микробиология и патогенность мепрозных бацилм и действие их на животных / И.И. КАитин // Воен.-мед. журн. - 1905. - № 9-10. C. 231-447.

37. Колесов, К.А. О результатах экспериментального заражения мышей материалом от больных мепрой / К.А. Колесов // Вестн. дерматол. - 1968. №10. - C. 55-59.

38. Косолапкина, А.И. Вопросы патоморфологии и гистологии мепры по материалам отечественной и зарубежной митературы за последние годы / А.И. Косолапкина, А.М. Чернышева, Г.Ф. Журавлева // Учен. зап. Ин-та по изучению мепры. - Астрахань, 1970. - №6 (11). - С. 109-121.

39. Кочемасова, 3.H. L-формы микобактерий туберкулеза / 3.Н. Кочемасова, М.М. Аыхно, И.Р. Аорожкова, Н.Г. Кассирская, А.Я. Баканова / Под реА 3.Н. Кочемасовой. - М.: Медицина, 1980. - 175 с.

40. Куликовский, А.В. Эмектронно-микроскопическое изучение атипичных нефотохромогенных микобактерий / А.В. Куликовский, В.П. Нелюбин, Г.А. Надточий / / Труды ВНИИ вет. санитарии. - 1972. - Т. 41. - С. 32-35.

41. Куляш, Г.Ю. Успехи и песпективы изучения патогенных микроорганизмов in vivo на модели имплантированных камер /Г.Ю. Куляш, Е.М. Головко, М.Н. Аяпин // Журн. микробиол. - 1991.- №4. -С. 72-76.

42. Курилов, В.Я. Тонкое строение капимляров кожи при мепроматозной проказе / В.Я. Курилов // Учен. зап. Ин-та по изучению мепры. - Астрахань, 1972. №7 (12). - С. 229-235.

43. Курилов, В.Я. Электронно-микроскопическое исследование возбудителей мепры человека и крыс (предварительное сообщение) / В.Я. Курилов // Учен. зап. Ин-та по изучению мепры. - Астрахань, 1968. - №5 (10). - С. 419-425.

44. Мартынова, В.А. Изучение экспериментальной мепрозной инфекции у облученных мышей / В.А. Мартынова, 3.В. Бадовская // Журн. микробиол. 1964. - № 5. - C. 82-87.

45. Маслов, А.К. БактерициАный эффект и активность миелопероксидазы макрофагов при персистировании микобактерий туберкулеза и мепры / А.К. Маслов // Вестн. новых мед. технол. - 1999. - № 1. - С. 76-79. 
46. Маслов, А.К. ВАияние пероксилазы в комплексе с основными противолепрозными средствами на функциональные способности фагоцитов, состояние печени и картину мышей с экспериментальной мепрой / А.К. Маслов, С.А. Аужнова, О.В. Кацянина // Бюл. эксперим. биол. - 2001. №11. - C. 551-553.

47. Маслов, А.К. ВАияние пероксидазы на развитие экспериментальной мепры у мышей, зараженных интраплантарно / А.К. Маслов, О.В. Калянина // Бюл. эксперим. биол. - 2000. - № 5. - С. 571-573.

48. Маслов, А.К. О роли мизосомальных ферментов макрофагов в патологии мепры / А.К. Маслов, А.А. Ющенко // Вестн. дерматол. - 1992. - № 1. C. 12-16.

49. Маслов, А.К. Оценка функционального состояния мепрозных макрофагов / А.К. Маслов, А.А. Ющенко // Арх. пат. - 1988. -№ 11. - С.51-54.

50. Маслов, А.К. Прогнозирование эффективности терапии мепры на основе данных электронной микроскопии / А.К. Маслов, А.А. Ющенко //Тез. Аокл. XIV конф. электронной микроскопии. - Черноголовка; М., 1992. - С. 60-60.

51. Маслов, А.К. УАьтрацитохимические особенности микобактерий при мепроматозном типе мепры и характер взаимоотношений возбудителя с клетками организма больного при рециливах заболевания: автореф. Аис. ... канА. меА. наук: защищена 15.12.82., утв. 04.05.83. / А.К.Маслов. М.: ВАСХНИА , 1982. - 20 с.

52. Маслов, А.К. Электронно-иммунохимическое выявление микобактериальных антигенов в гранулемах больных мепрой / А.К.Маслов, М.Н.Аячина / / Журн. микробиол. - 1996. - №1. - С. 84-87.

53. Маслов, А.К. Электронно-микроскопическое изучение Mycobacterium leprae, размножающихся в организме мышей при моделировании дефекта фагоцитов в мапах / А.К. Маслов // Тез. Аокл. 22 Рос. конф. по электронной микроскопии (2-6 июня 2008 г.) - Черноголовка: ИзА-во «Богородский печатник», 2008. - С. 297-297.

54. Маслов, А.К. Электронно-микроскопическое исследование в мепрологии /А.К. Маслов, А.А. Ющенко // Вестн. новых меА. технол. - 2001. - № 3. C. 71-73.

55. Маслов, А.К. Электронно-микроскопическое исследование Mycobacterium leprae, пассируемых на $а$ абораторных животных / А.К. Маслов, М.Н. Аячина // Журн. микробиол. - 2001. - № 5. - С. 20-23.

56. Маслов, А.К. ЭАектронно-цитохимическое изучение мокализации активности АТФ-азы в клетках возбудителя мепры /А.К. Маслов, А.А. Ющенко // Тез. Аокл. 18 Рос. конф. по электронной микроскопии. - Черноголовка, 2000. C. 267-267.

57. Меньшиков, А.А. УАьтраструктура микобактерий туберкулеза, чувствительных и устойчивых к антибактериацьным препаратам /А.А. Меньшиков [и Ар.]. // Пробл. туберкулеза. - 1971. - №5. - С. 64-69.

58. Модель, А.М. Биология и биохимия туберкулезных микобактерий / А.М. Модель. - М. : Иза. АМН СССР, 1952. - 248 с.

59. Определитель бактерий Берджи /под.реА. Аж. Хоулта [и Ар.]. - 9-е изА. в 2 т. М.: Мир, 1997. - Т.2. - С. 541, 606-607. 
60. Оттен, Т. Ф. Микобактериоз / Т. Ф. Оттен, А. В. Васильев. - СП/б, 2005. $-257 \mathrm{c}$.

61. Павловский, Г.Т. Изучение морфологических особенностей туберкулезных бактерий при помощи электронного микроскопа / Г.Т. Павловский, Н.М. Соколова // Пробл. Туберкулеза. - 1955. - № 3. - С. 61-65.

62. Первухин, Ю.В. Изучение некоторых биологических свойств штаммов микобактерий, вылеленных от больных мепрой и вызывающих при пассажах у мышей генерализованную инфекцию / Ю.В. Первухин, 3.В. БаАовская, 3.И. Бронфман и Ар. // Клиника, мечение и профикактика мепры. Астрахань, 1976. -№10 (15). - С. 122-129.

63. Первухин, Ю.В. Опыт экспериментальной инфекции возбудителем мепры человека мышей минии СВА / Ю.В. Первухин, 3.В. БаАовская // Учен. зап. Ин-та по изучению мепры. - Астрахань, 1972. - №7 (12). -С. 211-214.

64. Перельман, М.И. Национальное руководство. Фтизиатрия / М. И. Перельман. - М.: ГЭОТАР-МеАиа, 2007. - С. 75-91.

65. Перельман, М.И. Фтизиатрия / М.И. Перельман, В.А. Корякин, И.В. Богадельникова. - М.: ОАО ИзА-во «Медицина», 2004. - 394 с.

66. Пигаревский, В.Е. Гипотеза о резорбтивной клеточной резистентности как особой форме антимикробной защиты организма / В.Е. Пигаревский // Арх. патол. - 1992. - № 8. - С. 40-45.

67. Пинчук, А.М. Газожилкостная хроматография жирных кислот M.leprae, пассируемых на животных / А.М. Пинчук, М.Н. Аячина, А.А. Аазовская / /Актуальные вопросы мепрологии. - Астрахань, 1978. - С. 97-100.

68. Погорелов, В.Н. Попытка заражения морских свинок микобактериями мепры человека, мепры крыс и БЦЖ при введении им кортизона / В.Н. Погорелов, 3.В. Баловская // Учен. зап. Ин-та по изучению мепры. - Астрахань, 1964. №4 (9). - С. 154-160.

69. Покотинский, И.С. Электронно-микроскопические исследования морфологической структуры микобактерий туберкулеза / И.С. Покотинский, Н.М. Соколова, А.Е. Стремилова / / Пробл. туберкулеза. - 1960. - № 4. - 94-99.

70. Пушкарева, В.И. Покоящиеся формы Yersinia pseudotuberculosis при взаимодействии с зелеными водорослями и их экзометаболитами (популяционная Аинамика и ультраструктура) /В.И. Пушкарева, Е.Н. Емельяненко, А.В. Аиленко и Ар. // Журн. микробиол. - 1998. - №5. C. 9-13.

71. Троицкая, А.С. К вопросу о бактериоскопической Аиагностике мепры / А.С. Троицкая // Сб. науч. работ по мепрологии и дерматологии. Ростов-на-Аону, 1956. - № 8. - С. 110-115.

72. Цемлариус, И.К. Изучение динамики развития микобактерий и возможности эмектронно-микроскопической диагностики туберкулеза / И.К. Цемлариус / / Вестн. сельхоз. науки (укр.). - 1963. - №6. - С. 111-115.

73. Цембалару, Г.Г. Электронно-микроскопическое исследование изменений морфологической структуры микобактерий туберкулеза, возникающих поА влиянием антибактериальной терапии / Г.Г. Цембалару // Проб̆. туберкулеза. - 1967. - № 1. - 61-66. 
74. Чайкина, Т.Н. ЭАектронно-микроскопическое изучение микобактерий туберкулеза после Аействия на них противобактериальных препаратов / Т.Н. Чайкина, Г.А. Красников // Микробиол. журн. - 1966. - Т. 28, №6. C. 62-67.

75. Черткова, Э.И. Изучение Аействия активных химиопрепаратов на туберкулезную палочку с помощью электронного микроскопа / Э.И. Черткова, Н.И. Буйнов / / Пробц. туберкулеза. - 1953. - № 1. - С. 22-28.

76. Шахбанов, А.А. УАьтратонкая структура патогенных и атипичных микобактерий / А.А. Шахбанов, И.А. Гришаев // Тр. ВНИИ вет. санитарии. 1971. - T. 39. - C. 12-17.

77. Ющенко, А.А. К вопросу о выполнении программы ИММАЕП (электронномикроскопическое изучение M.leprae в тканях броненосцев) / А.А. Ющенко, А.К. Маслов // Актуальные вопросы мепрологии. - Астрахань, 1978. C. $120-125$.

78. Ющенко, А.А. Культивирование микобактерий мепры на подможках из перфторуглерода / А.А. Ющенко, О.А. Иртуганова // Актуальные вопросы мепрологии. - Астрахань, 1984. - С. 21-25.

79. Ющенко, А.А. Аепра / А.А. Ющенко, Ф.Е. Вишневецкий, В.А. Евстратова // БСЭ. - 3-е изА. - М., 1980. - Т. 13. - С. 34-50.

80. Ющенко, А.А. Материалы электронно-микроскопического изучения микобактерий мепры человека и некоторых Аругих микобактерий: автореф. Аис. ... канд. мед. наук : защищена 14.05.70. утв. 17.07.70. /А.А. Ющенко. M., 1970. - 26 c.

81. Ющенко, А.А. ЭАектронно-цитохимическое изучение АОФА-оксидаза микобактерий мепры / А.А. Ющенко, В.А. Клуб̆кин, А.К. Маслов // 13 Всесоюз. конф. по электронной микроскопии (биология и медицина) : тез. Аокл. - М., 1988. - С. 105-105.

82. Allen, J.M. Electron microscopy of the host-cell parasite relation in murine leprosy / J.M. Allen, Brieger E.M., Rees R.J.W. // J. Pathol. Bacteriol. - 1965. - Vol. 89. P. 301-306.

83. Almeida, J.G. The significance of dapsone (DDS) resistant M. leprae in untreated patients / J.G. Almeida [et al.] // Int. J. Lepr. - 1983. - Vol. 51. - P. 374-377.

84. Andrejak, C. Nontuberculous pulmonary mycobacteriosis in Denmark: incidence and prognostic factors / C. Andrejak,V.O. Thomsen, I.S. Johansen et al. // Am. J. Respir. Crit. Care Med. - 2010. - Vol. 181. - P. 514-521.

85. Aquino, T.I. Pathobiologic significance of the subcellular organelles of lepra cells / T.I. Aquino, O.K. Skinsnes, // Int. J. Lepr. - 1970. - Vol. 38. - P. 134-148.

86. Bapat, C.V. Cultivation of Mycobacterium leprae: a new approach /C.V. Bapat //Int. J. Lepr. - 1989. - Vol. 57. - P. 874-879.

87. Basserman, F. Untersuchungen zur Ultrastruktur des Tuberkulose - Erregers mittels elektronenoptischer Analyse von mykobakteriellen Ultradunnschnitten / F. Basserman // Z. Tuberk. 1958. - Bd. 3. - P. 1-12.

88. Bergel, M. Actividad cancerogenade de la diaminodifenilsulfona (D.D.S.) / M. Bergel // Lepr. India. - 1976. - Vol. 48. - P. 87-87. 
89. Bhamidi, S. Mycobacterial cell wall arabinogalactan. Bacterial polysaccharides. Current innovations and future trends / S. Bhamidi //Caister Academic Press. 2009. - P. 45-55.

90. Bishop, F.W. A comparative study by electron microscopy of the morphology of Mycobacterium leprae and cultivable species of mycobacteria / F.W. Bishop, L.G. Suhrland, C.M. Carpenter // Int. J. Lep. - 1948. - Vol. 16. - P. 361-366.

91. Boddingius, J. In situ location of Mycobacterium leprae - specific antigens. Immuno-electronoptical studies / J. Boddingius, H. Dycman // Acta Leprol. 1989. - Vol. 7. - P. 107-112.

92. Braganca, B.M. Metabolic aspects of human leprosy organisms / B.M. Braganca, K. Prabhakaran // Lepr. India. - 1960. - Vol. 32, №1. P. 94-97.

93. Brieger, E.M. Cytoplasmic structure in Mycobacterium leprae / E.M. Brieger, A.M. Glauert, J.M. Allen // Expl. Cell Res. - 1959. - Vol. 18. - P. 418-421.

94. Brieger, E.M. Electron microscopy of the leprosy bacillus, a study of submicroscopical structure / E.M. Brieger, A.M. Glauert / / Tubercle. - 1956. - Vol. 37. - P. 195-206.

95. Chatterjee, K.R. Electron microscopy and cytochemistry of Mycobacterium leprae and leprous tissue / K.R. Chatterjee // Lepr. India. - 1958. - Vol. 30. - P. 79-82.

96. Chatterjee, K.R. Growth habits of Mycobacterium leprae. Their implications / K.R. Chatterjee // Int. J. Lepr. - 1965. - Vol. 33. - P. 551-555.

97. Chatterjee, K.R. Growth of Mycobacterium leprae in a redox system III evidence of growth at low temperature (psychrophilia) and further refinement of growth medium / K.R. Chatterjee, R.D. Roy / / Lepr. India. - 1989. - Vol. 61. - P. 458-466.

98. Daley, C.L. Pulmonary non-tuberculous mycobacterial infections/ C.L. Daley, D.E. Griffith / / Int. J. Tuberc. - 2010. - Vol. 14. - P. 665-671.

99. Davidson, P.T. The diagnosis and management of disease caused by M. avium complex, M. kansasii, and other mycobacteria / P. T. Davidson // Clin. chest. Med. - 1989. - Vol. 10, № 3. - P. 431-443.

100. Delville, J.P. Relation between M. leprae and "diphtheroids" isolated from 13 leprosy patients / J.P. Delville // $10^{\text {th }}$ Int. Leprosy Congress: Abstracts. - Bergen, 1973. - P. 46-46.

101. Desikan, K.V. Fate of M.leprae inoculated into foot-pads of mice / K.V. Desikan // Lepr. India. - 1975. - Vol. 47. - P. 9-14.

102. Draper, P. Problems related for purification of M. leprae from armadillo tissues and standartization of M. leprae preparations / P. Draper // Report on the Enlarged S.C. Meeting. - Geneva, 1979. - WHO Document. Annex 1, 1/79. - P. 4-4.

103. Draper, P. The nature of the electron-transparent zone that surrounds M. lepraemurium inside host cells / P. Draper, R.J.W. Rees // J. Gen. Microbiol. 1973. - Vol. 77. - P. 79-87.

104. Edwards, R.P. Electron-microscope illustrations of division in Mycobacterium leprae / R.P. Edwards // Med. Microbiol. - 1970. - Vol. 3, №3. - P. 493-499.

105. Glauert, A.M. Membrane system in the cytoplasm of bacteria /A.M. Glauert, D.A. Howood // Proc. Europ. Reg. Conf. Electron Microscopy. - Delft, 1960. Vol. 2. - P. 759-762.

106. Global Tuberculosis Control / WHO report 2010. - 2010. - 204 p. 
107. Gordon, J. Surface peptide-glycolipid filaments on Mycobacterium leprae / J. Gordon, R.G. White // Clin. Exp. Immunol. - 1971. - Vol. 9. - P. 539-547.

108. Graham, R.C. The early stages of absorption of infected horseradish peroxidase in the proximal tubules of mouse kidney, ultrastructural cytochemistry by a new technique / R.C. Graham, M.J. Karnovsky // J. Histochem., Cytochem. - 1966. Vol. 14. - P. 291-302.

109. Griffith D.E. An official ATS/IDCA statement: diagnosis, treatment, and prevention of nontuberculous mycobacterial diseases // Am. J. Resp. Crit. Care Med. - 2007. - Vol. 175. - P. 367-416.

110. Griffith D.E. Diagnosing nontuberculous mycobacterial lung disease. A process in evolution / D.E. Griffith, B.A. Brown-Elliott, R. J. Jr. Walance // Infect. Dis. Clin. North Am. - 2002. - Vol. 16. - P. 235-249. Abstract.

111. Hanks, J.H. Capsules in electron micrographs of Mycobacterium leprae / J.H. Hanks, //Int. J. Lepr. - 1961. - Vol. 29. - P. 84-87.

112. Hanks, J.H. The application of metabolic studies to leprosy research / J.H. Hanks, C.T. Gray //Int. J. Lepr. - 1954. - Vol. 22. - P. 147-161.

113. Hansen, A. Bacillus leprae / A. Hansen // Virchows Archiv. - 1880. - Bd. 79. S. 32-42.

114. Hastings, R.C. Leprosy / Ed: R.C. Hastings. - Edinburgh, London, Melbourne and New York.: Churchill Livingstone, 1985. - 335 p.

115. Hestvik, A.L. Mycobacterial manipulation of the host cell / A.L. Hestvik, Z. Hmama, Y. Av-Gay //FEMS Microbiol Rev. - 2005. -Vol. 29. - C. 1041-1050.

116. Hirata, T. Cyto-morphological study of leprosy bacilli in the host cell / T. Hirata, T. Nakayama // Lepro. - 1975. - Vol. 44. - P. 163-176.

117. Hirata, T. Cyto-morphological study on M. leprae inoculated and grown in the mouse foot-pads / T. Hirata, T. Nakayama // Lepro. - 1975. - Vol. 44. - №3. P. 177-179.

118. Hirata, T. Origin of capsular structure around leprosy bacilli in the host cell. Electron microscopical observation / T. Hirata, T. Nakayama // Int. J. Lepr. 1974. -Vol. 42. - P. 120-120.

119. Houben, E.N. Interaction of pathogenic mycobacteria with the host immune system / E.N. Houben, L. Nguyen, J. Pieters // Curr. Opin. Microbiol. - 2006. Vol. 9. - P. 76-85.

120. Imaeda, T. Electron microscope study of Mycobacterium leprae and its environment in a vesicular leprous lesion / T. Imaeda, J. Convit // J. Bacteriol. 1962. - Vol. 83. - P. 43-52.

121. Imaeda, T. Formation of intracytoplasmic membrane system of mycobacteria related to cell division / T. Imaeda, M. Ogura // J. Bacteriol. - 1963. - Vol. 85. P. 150-163.

122. Imaeda, T. Ultrastructure of cell walls of genus mycobacterium /T. Imaeda, F. Kanetsuna, W. Galindo // J. Ultrastr. Res. - 1968. - Vol. 25. - P. 46-53.

123. Jaydip, G. Sporulation in mycobacteria / G. Jaydip, P. Larsson, B. Singh et al. //Proc. Nat. Acad. Sci. USA. -2009. - №26. - P. 10781-10786.

124. Kato, L. Autotropism of M. leprae / L. Kato // Int. J. Lepr. - 1973. - Vol. 41. - P. 519-519. 
125. Kato, L. Cytochrome pigments in M. leprae isolated from armadillos / L. Kato, M. Ishaque, G.P. Walsh // Microbios. - 1975. - Vol. 12. -P. 41-50.

126. Kato, L. The respiratory metabolism of Mycobacterium lepraemurium / L. Kato, C. Adapoe, M. Ishaque // Canad. J. Microbiol. - 1976. - Vol. 22. - P. 1293-1299.

127. Kavano, M. The studies on fine structure of M. tuberculosis / M. Kavano //Shikoku Acta Med. - 1960. - Vol. 16. - P. 683-689.

128. Khanolkar, S.R. Identification of Mycobacterium leprae antigens in tissues of leprosy patients using monoclonal antibodies / S.R. Khanolkar et al. // Int. J. Lepr. - 1989. - Vol. 157. - P. 423-425.

129. Kirchheimer, W.F. Attempts to establish the armadillo (Dasypus novemcinctus Linn) as a model for the study of leprosy. 1. Report of lepromatoid leprosy in an experimentally infected armadillo / W.F. Kirchheimer, E.E. Storrs // Int. J. Lepr. - 1971. - Vol. 39. -P. 693-702.

130. Kobayasi, T. Rutenium red staining of ultrathin section of human mast-cell granules / T. Kobayasi, G. Asboe-Hansen // J. Microscopy. - 1971. - Vol. 93. P. 55-60.

131. Koike, M. Fine structures of intracytoplasmic organelles of mycobacteria / M. Koike, K. Takeya // J. Biophys., Biochem., Cytol. - 1961. - Vol. 9. P. 597-608.

132. Kolbel, H. Untersuchungen am Mykobakterium tuberkulöses. V. Mitt uber die Vermechrung der Phosphatgranula / H. Kolbel // Zbl. Bakteriol., Infektionskrankh. Parasitenkunde, Hyg. - 1958. - Abt. I-Orig. - №6-7. P. 486-495.

133. Kusner, D.J. Mechanisms of mycobacterial persistence in tuberculosis / D.J. Kusner // Clin. Immunol. - 2005. - Vol. 114. - S. 239-247.

134. Kusunose, E. Occurrence of superoxide dismutase in Mycobacterium leprae grown on armadillo liver / E. Kusunose, M. Kusunose, K. Ichihara, S. Izumi // J. Gen. Appl. Microbiol. - 1980. - Vol. 26. - P. 369-372.

135. Manalang, J. The morphology of Mycobacterium leprae during the course of treatment / J. Manalang // Month. Bull. Bureau Health. - 1937. - Vol. 17. P. 3-10.

136. Maslov, A. K. Electron microscopic study of M.leprae passed on laboratory animals / A. K.Maslov, M.N. Dyachina // Int. J. Lepr. - 1993. - Vol. 61, № 4. (Suppl.). P. 113A-113A.

137. Matos, E.D. Nontuberculosis mycobacteria at a multiresistant tuberculosis reference center in Bahia / E.D. Matos, M.A. Santana, M.C. de Santana et al. //Braz. J. Infect. Dis. - 2004. - Vol. 8. - P. 296-304.

138. Matsuo, E. Acid mucopolysaccharide metabolism in leprosy. 2. Subcellular localization of hyaluronic acid and $\beta$-glucuronidase in leprous infiltrates suggestive of a host-Mycobacterium leprae metabolic relationship / E. Matsuo, O.K. Skinsnes // Int. J. Lepr. - 1974. - Vol. 42. - P. 399-411.

139. McFadzean, J.A. The examination and the determination of the viability of Mycobacterium leprae by electron microscopy / J.A. McFadzean, R.S. Valentine // Leprosy Rev. - 1960. - Vol. 31. - P. 6-11. 
140. Mistry, N.F. M. leprae phagocytosis and its association with membrane changes in macrophages from leprosy patients / N.F. Mistry, T.J. Birdi, N.H. Antia // Parasite Immunol. - 1986. - Vol. 8. - P. 129-138.

141. Mshana, R.N. Demonstration of mycobacterial antigens in leprosy tissues / R.N. Mshana et. al. // Int. J. Lepr. - 1982. - Vol. 50. - P. 1-10.

142. Mshana, R.N. Demonstration of mycobacterial antigens in nerve biopsies from leprosy patients using peroxidase-antiperoxidase immunoenzyme technique / R.N. Mshana, D.P. Humber, M. Harboe, A. Belehu // Clin. Immunol. Immunopathol. - 1983. - Vol. 29. - P. 359-368.

143. Nakane, P.K. Enzime-labeled antibodies for the light and electron microscopic localization of tissue antigens / P.K. Nakane, G.B.J. Pierce // J. Cell Biol. - 1967. Vol. 33. - P. 307-318.

144. Nishiura, M. An electron microscope study of the band structure of the leprosy bacillus and other mycobacteria / M. Nishiura, S. Okada, S. Izumi, H. Takizawa // Int. J. Lepr. - 1969. - Vol. 37. - P. 225-238.

145. Nishiura, M. The electron microscopic basis of the pathology of leprosy / M. Nishiura // Int. J. Lepr. - 1960. - Vol. 28. - P. 357-400.

146. Nishiura, M. The morphological difference between human and murine leprosy bacilli as revealed by the freeze-etching technic / M. Nishiura, K. Uehira, T. Hasegawa, M. Takeuchi // Int. J. Lepr. - 1972. - Vol. 40. - P. 89-90.

147. Pares, Y. Comportement d'une suspension bacillare issue d'un leprome et inoculee en nulieux nutritifs enrichis d'huile de paraffine / Y. Pares // Acta Leprol. - 1974. - № 55-56. - P. 27-34.

148. Pares, Y. Essais de culture de Mycobacterium leprae. Obtention de forms L. / Y. Pares // Acta Leprol. - 1970. - № 40-41. - P. 3-16.

149. Pares, Y. Mice en evidence de la production de formes L par le bacilli de Hansen. Examen des flacous et tubes ensemenses depuis un temps variable / Y. Pares // Ann. Fac. Sc. Dakar. - 1972. - № 25. - P. 27-36.

150. Pares, Y. Studies on the biological cycle of M. leprae / Y. Pares // Int. J. Lepr. 1973. - Vol. 41. - P. 528-529.

151. Prabhakaran, K. Biochemical studies on Mycobacterium leprae / K. Prabhakaran // Indian J. Lepr. - 1986. - Vol. 58. - P. 341-349.

152. Prabhakaran, K. Metabolism of M. leprae separated from human leprosy nodules / K. Prabhakaran // Int. J. Lepr. - 1967. - Vol. 35. - P. 34-41.

153. Prabhakaran, K. Oxidation of 3,4-dihydroxyphenylalanine (DOPA) by Mycobacterium leprae / K. Prabhakaran // Int. J. Lepr. - 1967. - Vol. 35. P. 42-51.

154. Prabhakaran, K. Particulate nature of diphenoloxidase in Mycobacterium leprae and assay of the enzyme by the radioisotope technique / K. Prabhakaran, E.B. Harris, W.F. Kirchheimer // Microbios. - 1973. - Vol. 8. - P. 151-157.

155. Prabhakaran, K. Binding of ${ }^{14} \mathrm{C}$-labeled DOPA by Mycobacterium leprae in vitro / K. Prabhakaran, E.B. Harris, W.F. Kirchheimer // Int. J. Lepr. - 1976. Vol. 44. - P. 58-64.

156. Prabhakaran, K. The nature of the phenolase enzyme in Mycobacterium leprae: structure-activity relationships of substrates and comparison with copper proteins 
and enzymes / K. Prabhakaran, E.B. Harris, W.F. Kirchheimer // Microbios. 1972. - Vol. 5. - P. 273-281.

157. Prabhakaran, K. Use of 3,4-dihydroxyphenylalanine oxidation in the identification of Mycobacterium leprae / K. Prabhakaran, W.F. Kirchheimer // J. Bacteriol. 1966. - Vol. 92. - P. 1267-1268.

158. Radanov, R. Etude an microscope electronique du Mycobacterium tuberculosis / R. Radanov, N. Spassova, E. Kalfin // Union Med. Balkan. - 1971. - Vol. 9. P. 711-715.

159. Radanov, R. Ultrastructure de Mycobacterium phlei influence par l'ethambutol / R. Radanov, N. Spassova, E. Kalfin // Arsh.Union med. Balkan. - 1973. Vol. 11. - P. 471-474.

160. Runion, E.N. Classification of mycobacteria / E.N. Runion // Med. Clin. North Amer. - 1959. - Vol. 43. - P. 273-279.

161. Russell, D.G. Mycobacterium tuberculosis: here today, and here tomorrow / D.G. Russell / / Nat. Rev. Mol. Cell Biol. - 2001. - №6. - P. 1095-1116.

162. Ryter, A.R. L'inclusion an polyester pour l'ultramicrotomie / A. R. Ryter, E. Kellenberger // Ultrastruct. Res. - 1968. - Vol. 25. - P.200-214.

163. Sato, S. Some problems on the fine structure of M. leprae and M. lepraemurium / S. Sato // Lepro. - 1968 - Vol.37. - P.1-11.

164. Sharp, A.R. Susceptibility of Mycobacterium leprae to bacterial activity of mouse peritoneal macrophages and to hydrogen peroxide / A.R. Sharp, M.J. Colston, D.K. Banerjee // Med. Microbiol. - 1985. - Vol. 19. - P. 77-84.

165. Shepard, C.C. The experimental disease that follows the injection of human leprosy bacilli into foot pads of mice / C.C. Shepard // Exp. Med. - 1960. - Vol. 112. P. 445-454.

166. Shinohara, C. Mitochondria-like structures in ultrathin sections of Mycobacterium avium / C. Shinohara, K. Fukushi, J. Suzuki // J. Bacteriol. - 1957. - Vol. 74. P. 413-415.

167. Shinohara, C. An electron microscopic study of bacilli. 14. Structure and function of mitochondria / C. Shinohara, J. Suzuki, K. Fukushi, K. Sato // Electr. microscopy. - 1959. - Vol. 7, № 2-3. - P. 63-64.

168. Skinsnes, O.K. In vitro cultivation of leprosy bacilli on hyaluronic acid based medium / O.K. Skinsnes, E. Matsuo, P.H.C. Chang, B. Andersson // Int. J. Lepr. - 1975. - Vol. 43. - P. 193-209.

169. Somoskovi, A. Laboratory diagnosis of nontuberculosis mycobacteria / A. Somoskovi, J. Mester, Y.M. Hale et al. // Clin. Chest. Med. - 2002. - Vol. 23. - P. 585-597.

170. Spurr, A.R. A low-viscosity epoxy resin embedding medium for electron microscopy / A.R. Spurr // Ultrastruct. Res. - 1969. - Vol. 26. -P. 31-43.

171. Toda, T. Electron microscopic studies on the ultracellular structures of mycobacterium in relation to function / T. Toda, K. Takeya, M. Koike //Int. Kongr. für Elektronmikroskopie. - Berlin, 1960. - S. 526-528.

172. Traag, B.A. Do mycobacteria produce endospores? / B.A. Traag, A. Driks, P. Stragier et al. // Proc. Natl Acad. Sci. U S A. - 2010. - Vol. 107. - P. 878-881. 
173. Vergne, I. Cell biology of mycobacterium tuberculosis phagosome / I. Vergne, J. Chua, S.B. Singh // Deretic. Annu. Rev. Cell Dev. Biol. - 2004. - Vol. 20. - P. 367-394.

174. Von Rhein C.F. Sources of disseminated Mycobacterium avium infection in AIDS / C.F. von Rhein et al. // J. Infect. - 2002. - Vol. 44. - P. 166-170.

175. Wade, H.W. "L" bodies or protoplasts of the leprosy bacillus? / H.W. Wade // Int. J. Lepr. - 1962. - Vol. 30. - P. 501-503.

176. Wager, O. Immunological aspects of leprosy with special reference to auto-immune diseases / O. Wager // Bull. WHO. - 1969. - Vol. 41. - C. 793-804.

177. Waters, M.F.R. Significance of fragmented leprosy bacilli /M.F.R. Waters // Int. J. Lepr. - 1967. - Vol. 35. - P. 519-520.

178. Whitehouse, R.L.S. Ultrastructure of Mycobacterium lepramurium / R.L.S. Whitehouse, P.C. Wong, F.L. Jackson // Int. J. Lepr. - 1971. - Vol. 39. P. 151-163.

179. Wilson, M.P. Immunofluorescence and related staining technique / M.P. Wilson, P.K. Nakane. - Amsterdam, 1978. - P. 215-216.

180. Yamamoto, T. Electron microscopy of Mycobacterium lepramurium in ultra-thin sections of murine leprosy lesions / T. Yamamoto, M. Nishiura, N. Harada, T. Imaeda // Int. J. Lepr. - 1958. - Vol. 26. - P. 111-114. 